\title{
W'HC-STD-C.CHBH-PLN. COA
}

Page 1 of 1

\section{DISTRIBUTION SHEET}

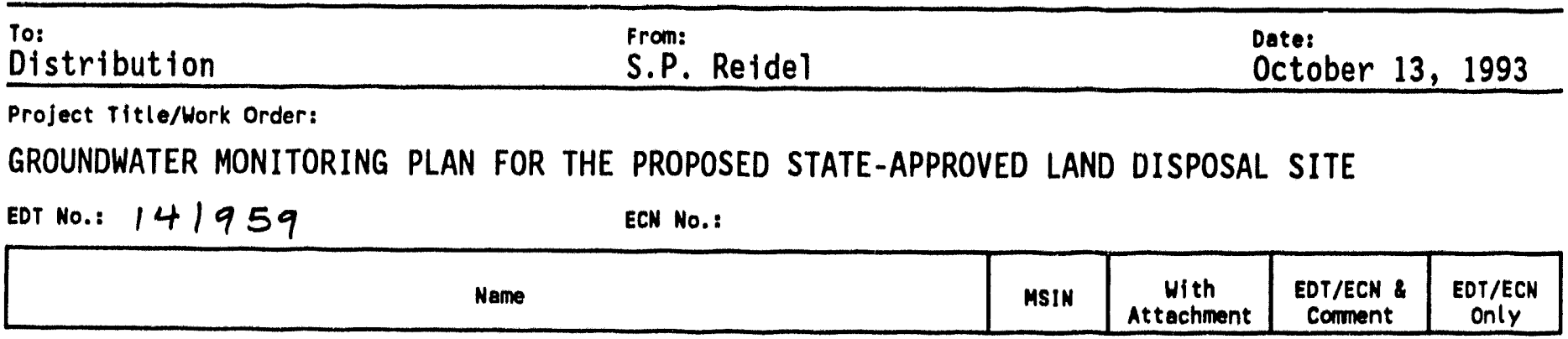

U. S. Department of Energy Field Office, Richland

M.K. Thompson

S.J. Lijek

A5-15 $X$

M.J. Furman

A4-45

A5-21

$x$
$x$

Westinghouse Hanford Company

W.R.-Owen \& D. Williams

D.E. Kelly

D.L. Flyckt

K.J. Koegler

S.P. Reidel

K.A. Lindsey

E.H. Thornton

K.R. Fecht

S.P. Skurla

T.W. Moon

M.E. Juguilon

W.R. O1dham

Information Release Admionstration

R3-45

R3-46

$x$

R3-45

H6- 05

H6-06

H6-06

H6- 05

H6-06

H6- 25

H6- 25

L4 - 76

H6-25

LENTRal Filos

H4-17

$48-04$

$x$

$x(2)$

$x(5)$

$x$

$X(3)$

$x$

$x$

$x$

$x(2)$

$x$

$x$

\section{DISCLAIMER}

This report was prepared as an account of work sponsored by an agency of the United States This report was prepared as an account of work sponsor any agency thareof, nor any of their employees, makes any warranty, express or implied, or assumes any legal liability or responsiemployees, makes any warranty, express or implied, of ass information, apparatus, product, or bility for the accuraced, or represents that its use would not infringe privately owned rights. Referprocess disclosed, or represents that its use would not infringe privately owned rights. Reference herein to any specific commercial product, process, or service by its endorsement, recommanufacturer, or otherwise does not necessarily constitute or imply its endorsenent, recom mendation, or favoring by the United States Government or any agency thereof. The views
and opinions of authors expressed herein do not necessarily state or reflect those of the United States Government or any agency thereof. 


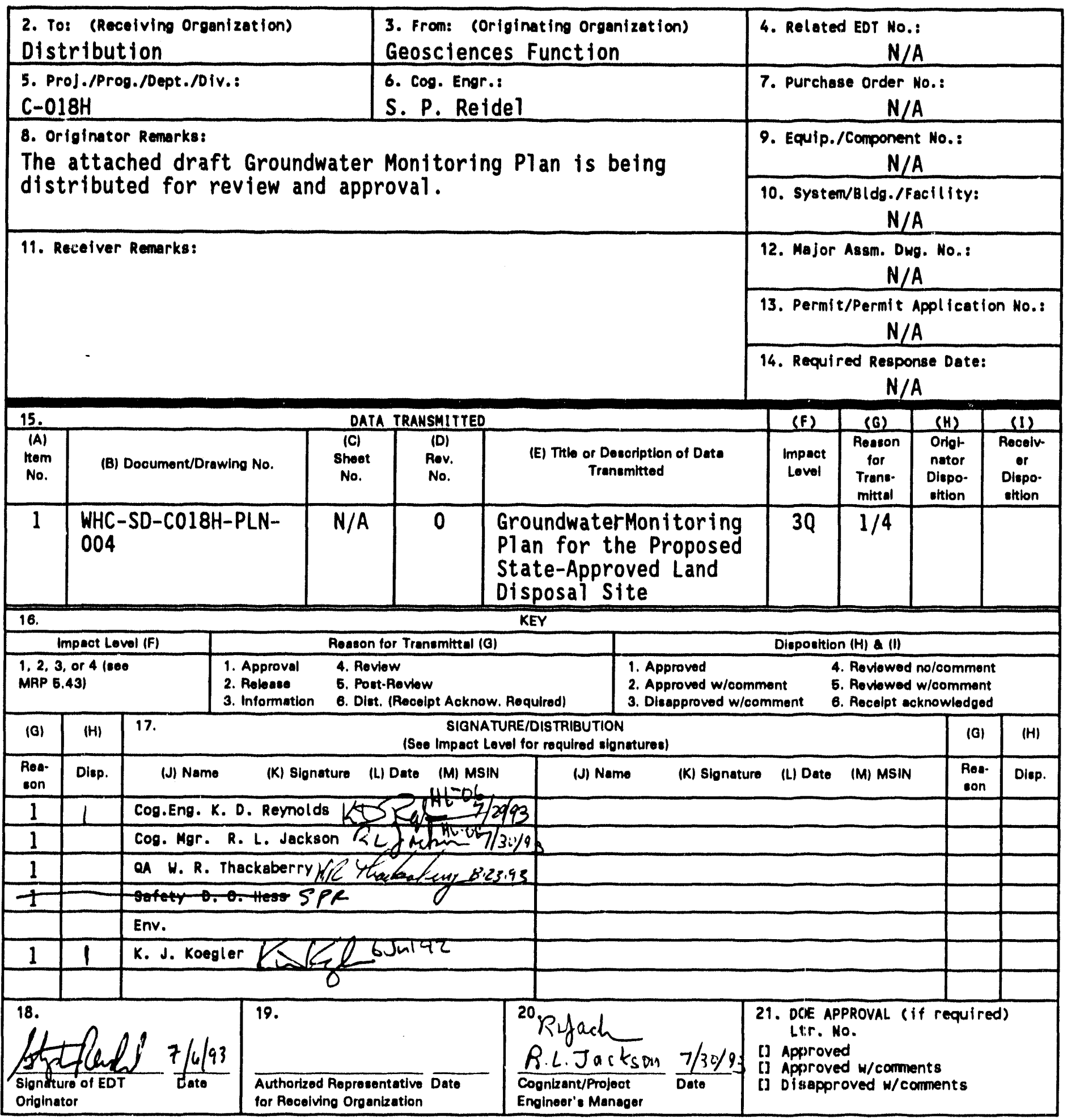

BD-7400-172-2 (07/91) GEF097 


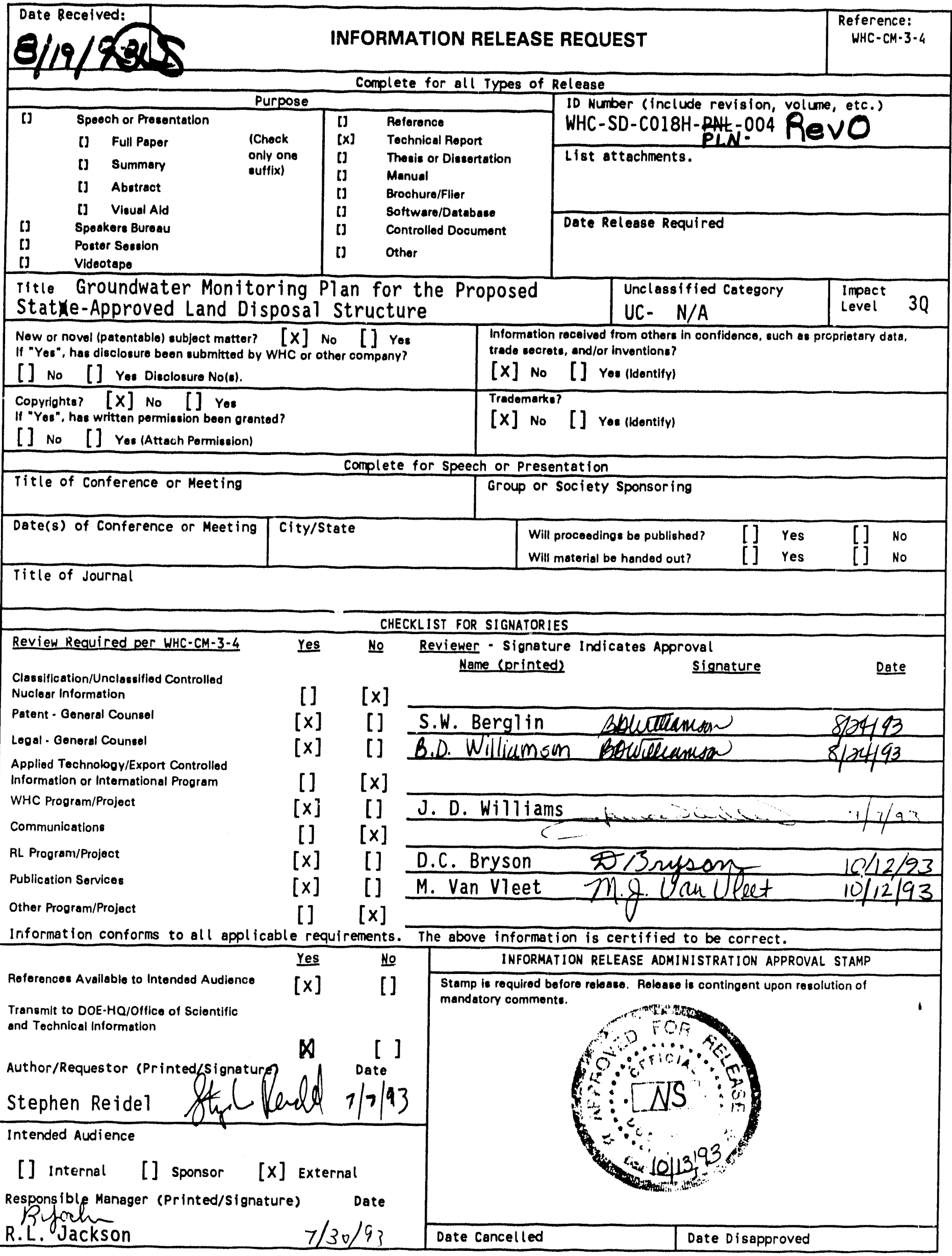


2. Title

Groundwater Monitoring Plan for the Proposed State-Approved Land Disposal SITE

5. Key Words

Groundwater Monitoring Plan
3. Number

WHC-SD-CO18H-PLN004

6. Author

Name: S.P. Reide]

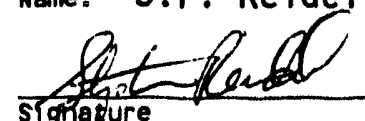

Organization/Charge Code
4. ReV No.

0

\section{APPROVED FOR} PUBLIC RELEASE

\section{Abstract}

\section{1/3/930. Doles}

This document describes the proposed groundwater monitoring system for the proposed State-Approved Land Disposal Site.

8. ADPOSE AND USE OF DOCUMENT - This document was prepared for we witin the U.S. Department of Energy and its contractors. Wh to be use only to perform, direct, or integrate in under U.S. Deparuant of Energy contracts. This document not approved for public renne until reviewed.

PATENT STATUS - This mament cony since it is transmitted in advance of patent clearance, we available in confidence solely for use in performance of wounder contracts with the U.S. Department of Engyy. This documenn not to be publ ished nor its contents othenuse disseminated or used fomeurposes other than specified abou before patent approval for such retrane or use has been secined, upon request, from the Patent Counsel, U.S. Depment of En-igy Field Office, Richland, WA.

DISCLAIMER - This report was prepared as an account of work sponsored by an agency of the United States Goverment. Neither the United States Government nor any agency thereof, nor any of their employees, nor any of their contractors, subcontractors or their employees, makes any warranty, express or implied, or assumes any legal liability or responsibility for the accuracy, completeness, or any third party's use or the results of such use of any information, apparatus, product, or process disclosed, or represents that its use would not infringe privately owned rights. Reference here in to any specific commercial product, process, or service by trade name, trademark, manufacturer, or otherwise, does not necessarily constitute or imply its endersement, recommendation, or favoring by the United States Government or any agency thereof or its contractors or subcontractors. The views and opinions of authors expressed herein do not necessarily state or reflect those of the United States Government or any agency thereof.

9. Impact Level $3 Q$
10.

RELEASE STAMP

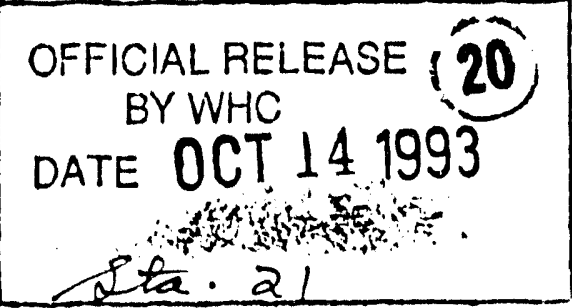




\section{CONTENTS}

1.0 INTRODUCTION

1.1 PURPOSE AND OBJECTIVES $\ldots \ldots \ldots \ldots \ldots$

2.0 BACKGROUND INFORMATION ................... 3

2.1 FACILITY DESCRIPTION ................. 3

2.1.1 Location and Physical Description .......... 3

2.1 .2 History of Operations ............ 6

2.2 GEOLOGY

2.2.1 Regionai Geologic setting $\ldots \ldots$

2.2.2 Geology of the State-Approved Land Disposal ...... g

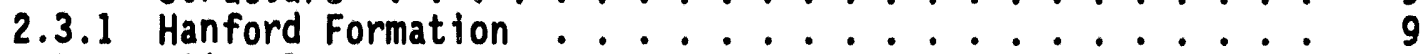

2.3.2 Plio-Pleistocene Unit and Early "Palouse" Soli ..... 9

2.3.3 Ringold Formation ............... 11

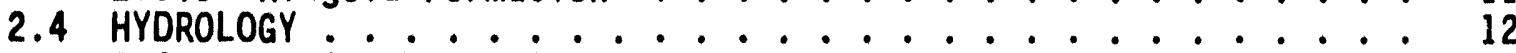

2.4.1 Regional Setting ............... 12

2.4 .2 Uppermost Aquifer System .......... 14

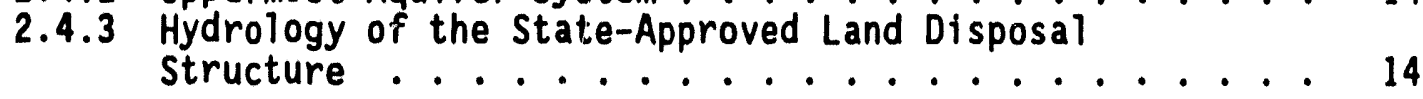

3.0 PHASE I--GROUNDWATER MONITORING PROGRAM . . . . . . . . 33

3.1 OBJECTIVES ...................... 33

3.2 APPROACH $\ldots \ldots 33$

3.3 GROUNDWATER MONITORING SYSTEM . . . . . . . . . 35

3.3.1 Uppermost Aquifer . . . . . . . . 35

3.3.2 New Characterization/Monitoring Welis ....... 35

3.3.3 Justification for New Well Locations ....... 35

3.3.4 Justification for Using Existing Monitoring Welis ... 41

3.3.5 Monitoring Parameters ............... 44

3.4 HYDROGEOLOGIC CHARACTERIZATION $\ldots \ldots$

3.4.1 Geologic Characterization ........... 46

3.4 .2 Hydrogeologic Characterization......... 47

3.5 SAMPLING AND ANALYSIS ............... 49

3.6 STATISTICAL ANALYSIS OF GROUNDWATER MONITORING DATA .... 50

3.6 .1 Methods ............... 50

3.6.2 Establishing Background ............ 50

3.6.3 Evaluation of Data .............. 50

3.6.4 Notification and Reports .............. 51

4.0 PHASE II--INITIATION OF GROUNDWATER QUALITY ASSESSMENT PROGRAM . . . 53

4.1 INITIATION CRITERIA . . . . . ......... 53

4.2 GROUNDWATER QUALITY ASSESSMENT PROGRAM .......... 53

4.2.1 Nature and Extent of Contamination . . . . . . . . 55

4.2.2 Rate of Movement . . . . . . . . 55

4.2.3 Additional Well Installation ........... 55

4.2.4 Additional Field and Laboratory Testing ........ 55

4.2 .5 Modeling . . . . . . . . . . . . 56

4.3 CONTINUED ANALYSIS AND EVALUATION . . . . . . . . . 56

4.3.1 Review of Methods and Procedures . . . . . . . . . . 56

4.3.2 Review of Sampling Parameters and Frequency ..... 57

4.3.3 Notification and Reports ............ 57 
CENTER (cont.)

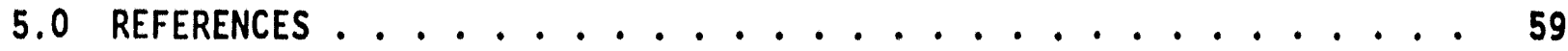
Appendixes:

A. Geologic and Well Construction Diagrams for Existing Wells . . . . A-i

B. Sampling and Analysis Plan ................. B-i 


\section{LIST OF FIGURES}

1 Location of the State-Approved Land Disposal Structure ...... 2

2 Location Map Showing Preferred State-Approved Land Disposal

Structure..................... 4

3 North-South Cross Section Through the Sedimentary Units Above the Columbla River Basalt Group at the Preferred State-Approved

Land Disposal Structure .................5

4 Structural Setting of the Preferred State-Approved Land Disposal

structure ..................... 7

5 Stratigraphic Nomenclature of the Hanford Site . . . . . . . 8

6 Stratigraphic Units and Lithology Penetrated at the Proposed State-Approved Land Disposal Structure by Borehole 699-48-77A . . . . 10

7 Areas of Artificial Recharge on the Hanford Site . . . . . . . . 13

8 Water Table at the Hanford Site . . . . . . . . . . . . 15

9 Water Table Map for the Preferred State-Approved Land Disposal Structure and Vicinity ............... 17

10 Location of New Groundwater Monitoring Wells . . . . . . . . . . 34

11 Groundwater Monitoring Well Efficiency for the State-Approved Land Disposal Structure Using a Hydraulic Gradient of N $20^{\circ} \mathrm{E}$. . . 37

12 Groundwater Monitoring Well Efficiency for the State-Approved Land Disposal Structure Using a Hydraulic Gradient of N $30^{\circ} \mathrm{E}$. . . . 38

13 Groundwater Monitoring Well Efficiency for the State-Approved Land Disposal Structure Using a Hydraulic Gradient of N $40^{\circ} \mathrm{E}$. . . . 39

14 Groundwater Monitoring Well Efficiency for the State-Approved Land Disposal Structure Using a Hydraulic Gradient of N 50 E . . . . 40

15 Groundwater Monitoring Well Efficiency for Borehole 699-48-77A as an Upgradient Well ................ 42

16 Schematic Diagrams of a Monitoring Well ........... 43 


\section{LIST OF TABLES}

1 Location of Boreholes at the State-Approved Land Disposal

Structure ........................ 3

2 Contamination Indicator Parameters Used for Borehole 699-48-77A . . . 19

3 Groundwater Analyses for Borehole 699-48-77A . . . . . . . . . . 24

4 Monitoring Efficiency for Two Proposed Downgradient Wells . . . . . 36

5 Groundwater Sampling Parameters, Maximum Level . . . . . . . . . 45

6 Reports and Notifications ................. 58 


\section{LIST OF TERMS}

CRBG

CRQL

DOE

DWS

Ecology

EPA

NTU

PNL

QA

QC

RCRA

SALDS

WDOE
Columbla River Basalt Group

contract required quantitation 1 imits

U.S. Department of Energy

drinking water standard

Washington State Department of Ecology

U.S. Environmental Protection Agency

nephelometric turbidity unit

Paclfic Northwest Laboratory

quality assurance

quality control

Resource Conservation and Recovery Act of 1976

state-approved land disposal structure

Washington Department of Ecology 
This page intentionally left blank. 


\section{GROUNDWATER MONITORING PLAN FOR THE PROPOSED}

STATE-APPROVED LAND DISPOSAL STRUCTURE

\subsection{INTRODUCTION}

This document outlines a detection-level groundwater monitoring program for the state-approved land disposal structure (SALDS). The SALDS is an infiltration basin proposed for disposal of treated effluent from the 200 Areas of the Hanford Site. The site is bounded by Hanford Site coordinates N48000, N48175, W76910, and W77090 (Figure 1). Treated effluent will be discharged to the SALDS as a state-approved land disposal site, per WAC 173-216.

\subsection{PURPOSE AND OBJECTIVES}

The purpose of this $\mathrm{plan}$ is to present a groundwater monitoring program that is capable of determining the impact of effluent disposal at the SALDS on the quality of groundwater in the uppermost aquifer. Specific objectives of this plan include the following:

- Develop an initial groundwater monitoring system that can provide an indication of any constituents that migrate from the site

- Provide a detailed sampling and analysis plan.

This groundwater monitoring plan presents an overview of the SALDS, the geology and hydrology of the area, the background and indicator evaluation (detection) groundwater monitoring program, and an outline of a groundwater quality assessment (compliance) program. This plan does not provide a plan for institutional controls to track tritium beyond the SALDS.

The plan for the monitoring program is based on groundwater monitoring requirements for the Resource Conservation and Recovery Act of 1976 (RCRA) interim-status facilities. If the Washington State Department of Ecology (Ecology) determines that a potential to pollute the groundwater exists for Project $\mathrm{C}-\mathrm{O} 18 \mathrm{H}$ and requires submittal of a groundwater quality evaluation program, this groundwater monitoring plan satisfies the minimum requirements of WAC-173-200-080(3), (4), and (5).

The monitoring requirements for an RCRA interim-status facility are described in 40 CFR 265 Subpart F and WAC 173-303-400; the WAC 173-303-400(3)(a) refers to 10 CFR 265 Subpart $F$ for interim status groundwater monitoring regulations. 
Figure 1. Location of the State-Approved Land Disposal Structure.

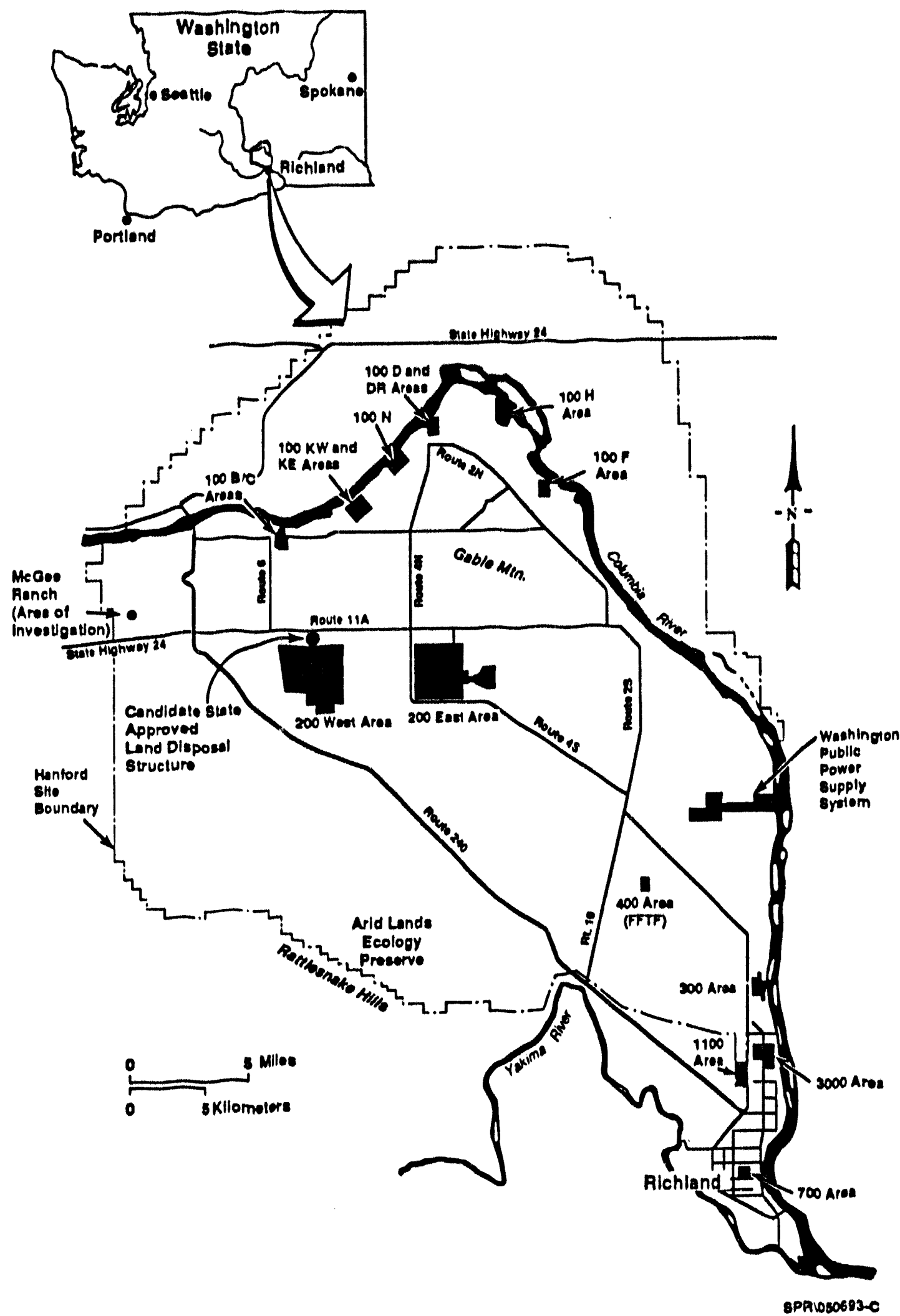




\subsection{BACKGROUND INFORMATION}

The U.S. Department of Energy (DOE)-operated Hanford Site is located in southeastern Washington State, approximately $274 \mathrm{~km}$ (170 mi) southeast of Seattle and $201 \mathrm{~km}(125 \mathrm{mi})$ southwest of Spokane (see Figure 1). The Hanford Site is a U.S. Government nuclear materials facility which, in the past, included nuclear reactor operation, storage and reprocessing of spent nuclear fuel, and management of radioactive and hazardous wastes. Present activities primarily involve management of radioactive and hazardous waste. The fuel reprocessing and radioactive waste management facilities are in the 200 East and 200 West Areas (Separations Area). More than 45 years of federal government operations in these areas has resulted in the storage, disposal, and release of radioactive and/or hazardous wastes.

\subsection{FACILITY DFSCRIPTION}

\subsubsection{Location and Physical Description}

The site proposed for the SALDS is located approximately $183 \mathrm{~m}(600 \mathrm{ft})$ north of the 200 West Area of the Hanford Site (Figures 2 and 3). The facility will be designed to receive an effluent volume of approximately $568 \mathrm{~L} / \mathrm{min}(150 \mathrm{gal} / \mathrm{min})$. The required surface area of the disposal facility is $2,007 \mathrm{~m}^{2}\left(21,600 \mathrm{ft}^{2}\right)$, which is based on an infiltration rate of $38 \mathrm{~L} / \mathrm{day} / \mathrm{m}^{2}\left(10 \mathrm{gal} / \mathrm{day} / \mathrm{ft}^{2}\right)$.

Two boreholes were drilled at the site (Table 1). Borehole 699-48-77A was drilled to the top of basalt and is an RCRA-compliant groundwater monitoring well. Borehole $699-48-77 \mathrm{~B}$ was drilled to a depth of $60 \mathrm{ft}$ and abandoned.

Table 1. Location of Boreholes at the State-Approved Land Disposal Structure.

\begin{tabular}{|c|c|c|c|c|c|c|c|}
\hline \multirow[b]{2}{*}{ Well no. } & \multicolumn{2}{|c|}{ Coordinates } & & \multicolumn{4}{|c|}{ Elevations (NGVD'29 ft) } \\
\hline & $200 \mathrm{~W}(\mathrm{ft})$ & $\begin{array}{l}\text { Lambert } \\
\text { NAD'83 (m) }\end{array}$ & & $\begin{array}{c}\text { Top of } \\
\text { brass } \\
\text { cap }\end{array}$ & $\begin{array}{c}\text { HydroStar } \\
\text { plate } \\
\text { N. side }\end{array}$ & $\begin{array}{l}\text { Top of } \\
\text { outer } \\
\text { casing } \\
\text { N. side }\end{array}$ & $\begin{array}{l}\text { Top of } \\
\text { inner } \\
\text { casing } \\
\text { N. side }\end{array}$ \\
\hline \multirow[t]{2}{*}{$699-48-77 A$} & $N=47602.7$ & $N: 137,969.02$ & NGVD' 29 & 672.25 & 674.74 & 674.72 & $N / A$ \\
\hline & $W: 77020.0$ & $E: 566,413.57$ & & & & & \\
\hline \multirow[t]{2}{*}{$699-48-77 B$} & $N: 47590.0$ & $N: 137,965.15$ & NGVD' 29 & 671.73 & $N / A$ & $N / A$ & $N / A$ \\
\hline & $W: 77013.3$ & $E: 566,415.60$ & & & & & \\
\hline
\end{tabular}

"HydroStar is a trademark of Instrumentation Northwest, Inc., Redmond, Washington.

$N A D=$ North American Datum. 
Figure 2. Location Map Showing Preferred State-Approved Land Disposal Structure.
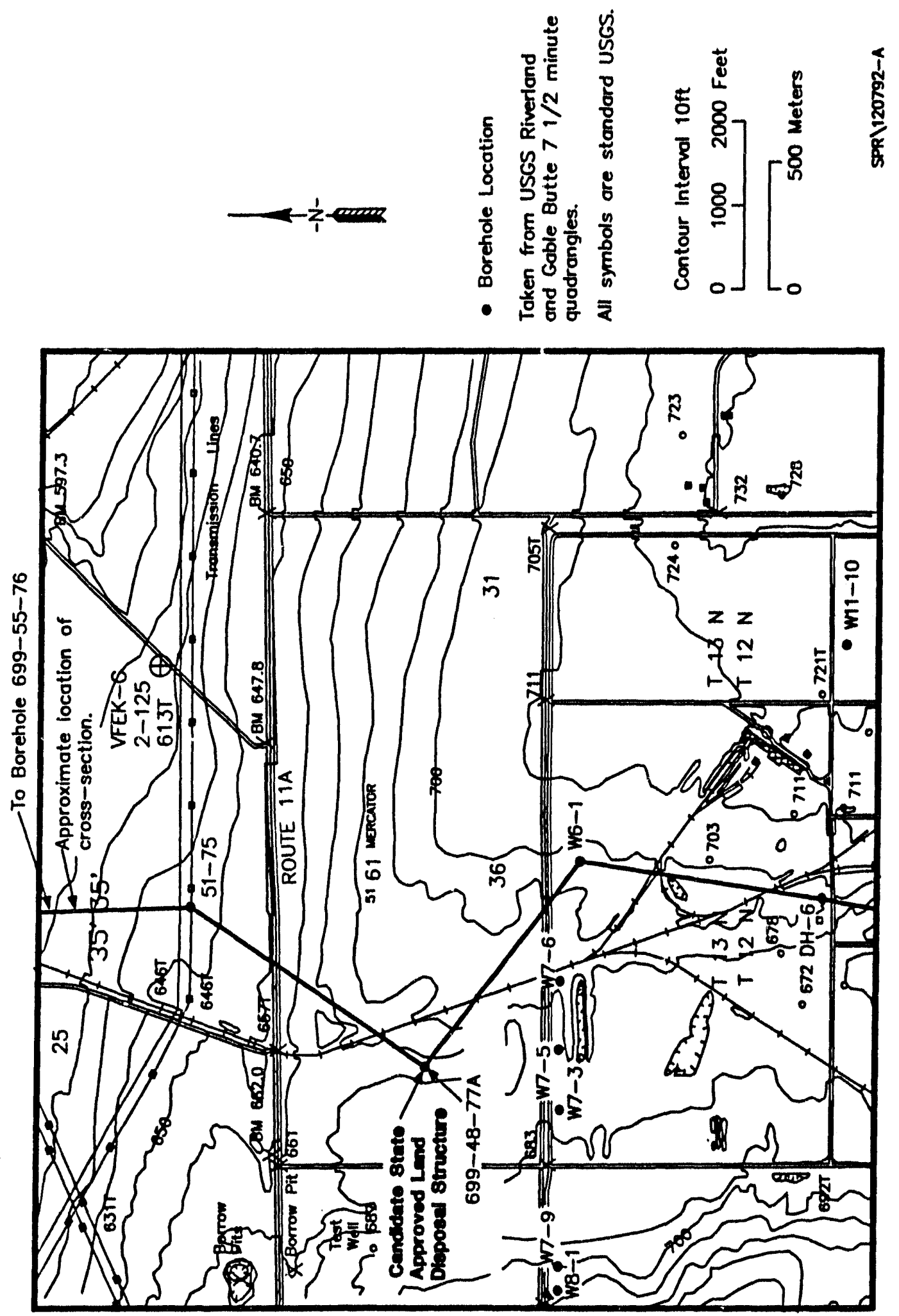
Figure 3. North-South Cross Section Through the Sedimentary Units Above the Columbia River Basalt Group at the Preferred State-Approved Land Disposal Structure.

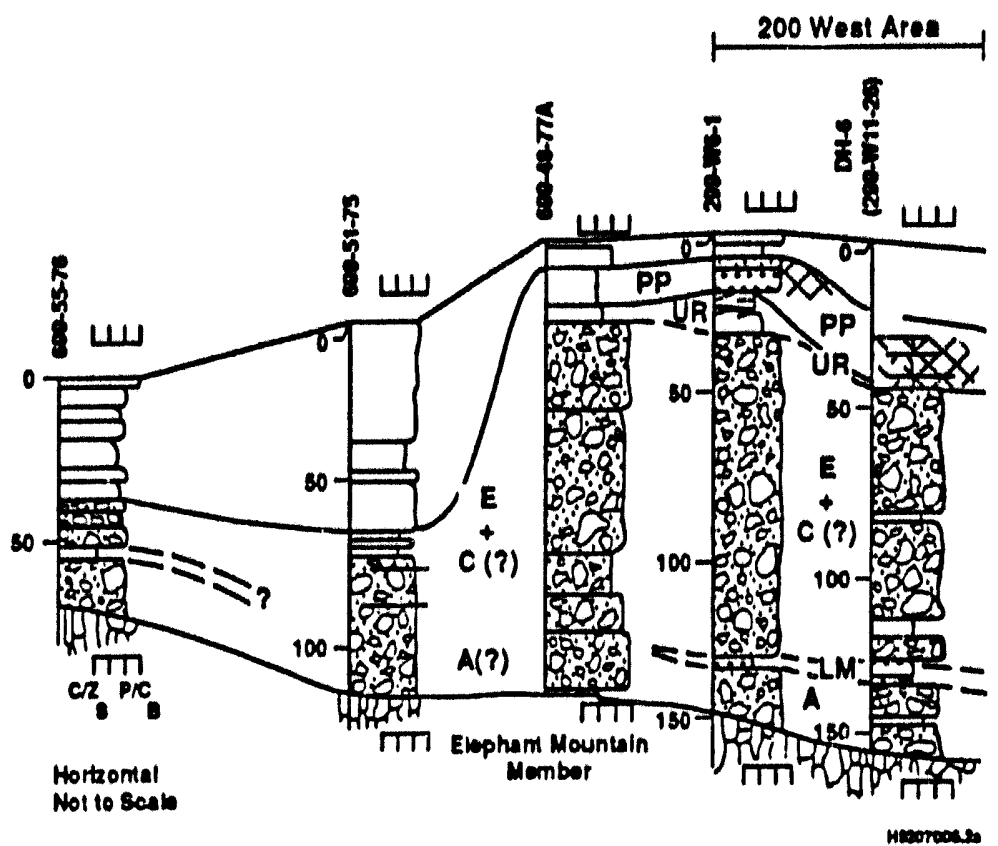

Explonotion for Crose-Section

Groin Slze Scole - Hortzontal Rellef of Soction Indicotoe Gron size of Dominant Portides in Bod.

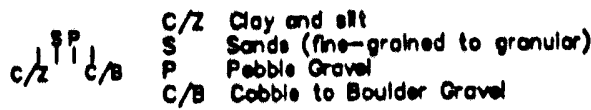

Other Uthologies

Bif cobbly/bouldery

Pili: Pobbly

Sondy

E.i. sint rich

E-] Cloy riah

Ii. Poleoed

-1 Corbonoto-rich

F+74 Achy

EDit Columblo River Bosalt Croup

Other Symbolo

- Formation mojor unit contocts

- Fociet contoet

Wili Cementotion/Compoction

Abbrowations

PU - pro-Miseoulo orowis

cp - eorly "Polouso soll

Pp - Pllo-piolotocene unit

UR - Upper unlt, Ringold Formotion

- Uppermost orovi-dominoted sequence. Ringold formotion

- Lomermoet oroud-dominated equence Ringeld formotion

A, C.D- Discontinuous orow-domhoted enquences below unit $E$ and obov unit $A$. Ringold formotion

in - Lower mud (inne-groinod) equence. Ringold Formotion 


\subsubsection{History of Operations}

The SALDS is a proposed effluent disposal facility and to date has not received discharges to the site. The facility will receive liquid effluent from the 242-A Evaporator (Effluent Treatment Facility) and is scheduled to begin operations in October 1994.

\subsubsection{Waste Characterization}

The effluent to be disposed in the SALDS is composed of waste water that w1ll be treated using Best Available Technology/All Known and Reasonable Technologies as described in Project $\mathrm{C}-\mathrm{O}$-18H Waste Water Engineering Alternatives Report (WHC 1992b). Because the 242-A Evaporator is not in operation, data on actual treated effluent concentrations are not available. However, the treated effluent is anticipated to be below groundwater protection standards and EPA health-based levels (EPA 1992) at the groundwate:point of compliance using best engineering judgement.

\subsection{GEOLOGY}

\subsubsection{Regional Geologic Setting}

The Hanford Site lies within the Columbia Plateau, which consists of a thick sequence of tholeiltic basalt flows called the Columbia River Basalt Group (CRBG). These flows have been folded and faulted over the past 17 millition years, creating broad structural and topographic basins separated by asymmetric anticlinal ridges. Sediments up to $518 \mathrm{~m}(1,700 \mathrm{ft})$ in thickness have accumulated in some of these basins. Basalt flows of the CRBG are exposed along the anticlinal ridges where they have been uplifted as much as $1,097 \mathrm{~m}(3,600 \mathrm{ft})$ above the surrounding area. Overlying the CRBG in the synclinal basins are sediments of the late Miocene, Pliocene, and Pleistocene age. The Hanford Site lies within one of the larger basins, the Pasco Basin. The Pasco Basin is bounded on the north by the Saddle Mountains and on the south by Rattlesnake Mountain and the Rattlesnake Hills (Figure 4). Yakima Ridge and Umtanum Ridge trend into the basin and subdivide it into a series of anticlinal ridges and synclinal basins. The largest syncline, the cold Creek syncline, lies between Umtanum Ridge and Yakima Ridge and is the principal structure containing the DOE waste management areas. The geology of the Hanford Site has been described in detail by DOE (1988a, Vol. 1).

Principal stratigraphic units within the Hanford Site include, in ascending order, the CRBG (Miocene), the Ringold Formation (Miocene-Pliocene), Plio-Pleistocene unit-early "Palouse" soil, and the Hanford formation (Pleistocene) (Figure 5). A regionally discontinuous veneer of recent alluvium, colluvium, and/or eolian sediments overlies the principal geologic units. 
Figure 4. Structural Setting of the Preferred State-Approved Land Disposal Structure.

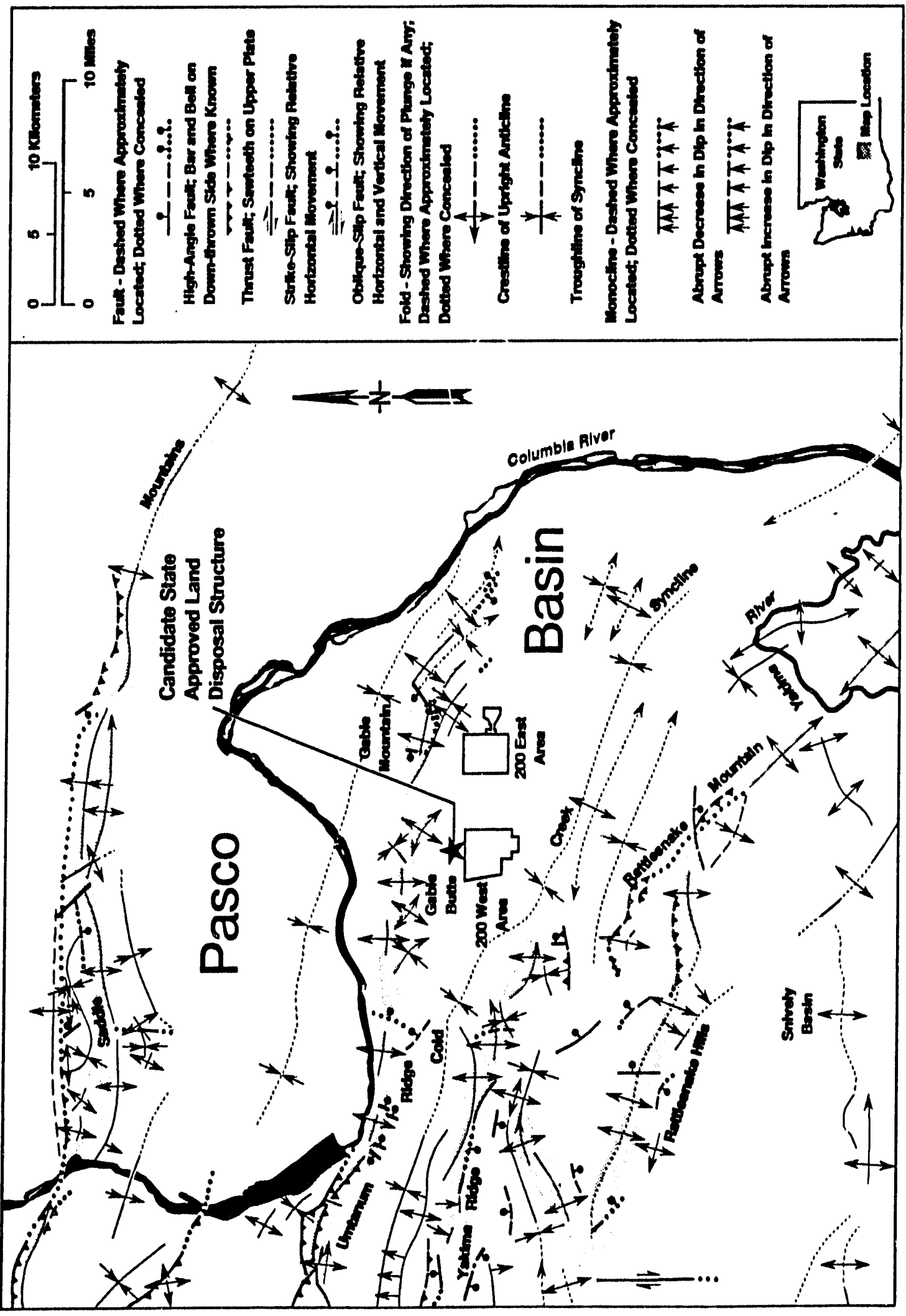


Figure 5. Stratigraphic Nomenclature of the Hanford Site.

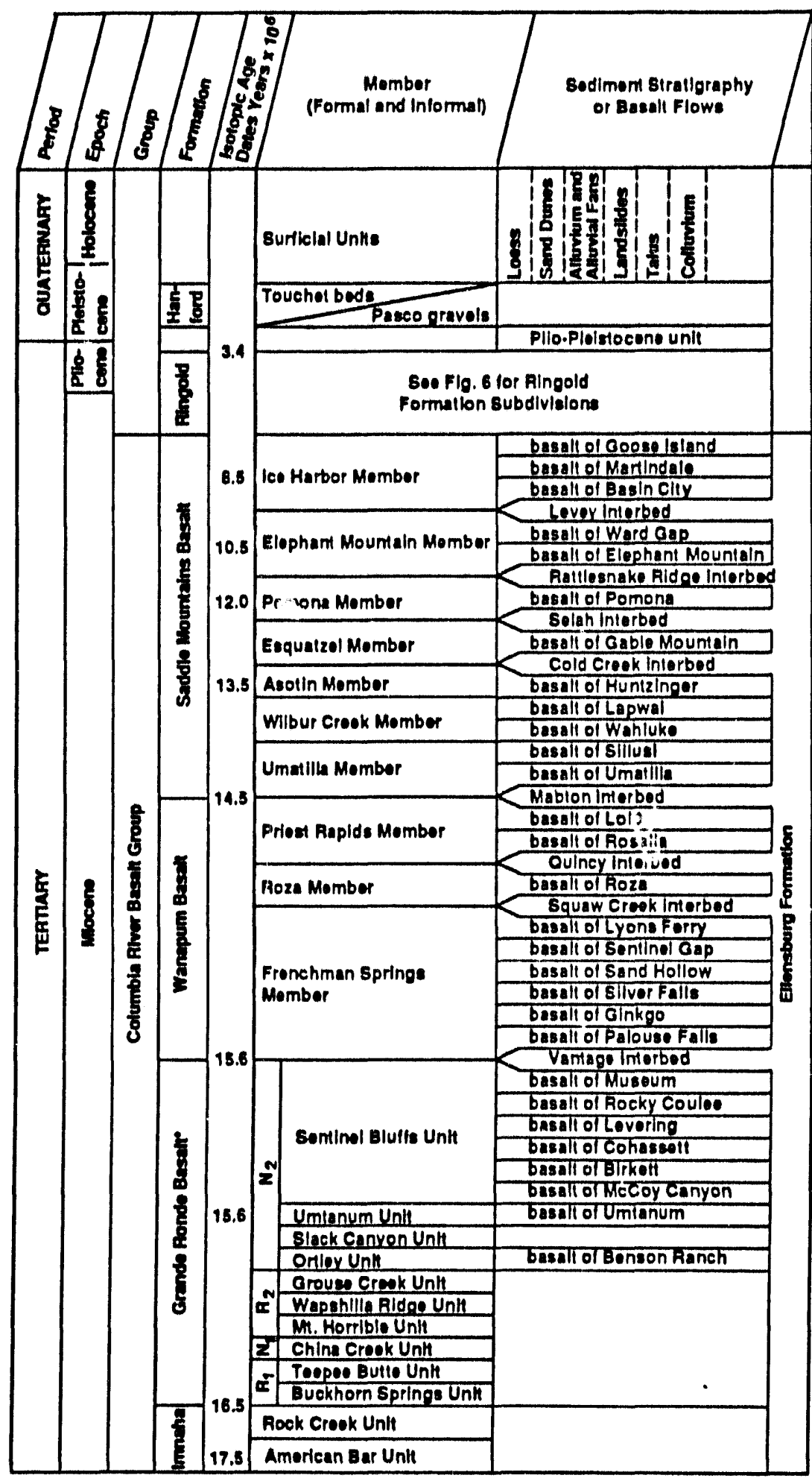

- The Orando Ronde Besall conalate of al loast $120 \mathrm{major}$ basall llowe. Only a low llows have been namod. $N_{2}, R_{2}, N_{1}$ and $R_{1}$ are magnelostratigraphic unile. 


\subsubsection{Geology of the State-Approved Land Disposal Structure}

The geology of the site proposed for the SALDS was determined from examination of well logs and integration of these data with published stratigraphic correlations. The results of well drilling and characterization activities have been described by WHC (1993). This section is derived from that report. Additional subsurface investigations will be incorporated into this characterization.

2.2.2.1 Structural Framework. The structural grain of the bedrock at the preferred SALDS trends roughly east-west parallel to the major geologic structures bounding the SALDS. The Gable Butte segment of the Umtanum Ridge anticline lies to the north and the Cold Creek syncline and Yakima Ridge anticline lie to the south (see Figure 4). As a result, the Ringold Formation and the underlying CRBG gently dip to the south off the Umtanum Ridge anticline into the cold Creek syncline. Major stratigraphic variations occur in a north-south direction parallel to the dip direction.

Geologic mapping at the Hanford Site has not identified any faults in the vicinity of the SALDS (see Figure 4) (DOE 1988a). The closest faults are along the Umtanum Ridge-Gable Mountain structure north of the SALDS.

2.2.2.2 Proposed State-Approved Land Disposal Structure Stratigraphy. The stratigraphy at the SALDS has been determined from well logs from two boreholes, 699-48-77A and 699-48-77B (WHC 1993). Both well locations are approximately $122 \mathrm{~m}(400 \mathrm{ft})$ south of the proposed SALDS facility. Borehole 699-48-77B was drilled to a depth of $18 \mathrm{~m}(60 \mathrm{ft})$ west of $699-48-77 \mathrm{~A}$. The stratigraphy encountered in both boreholes is identical.

Borehole 699-48-77A was drilled using the cable-tool drilling method and core barrel sample recovery to a depth of $139 \mathrm{~m}(455 \mathrm{ft})$, where the Elephant Mountain Member of the CRBG was penetrated. The stratigraphy encountered in borehole 699-48-77A is summarized in Figure 6. This section describes the lithology penetrated in the borehole and the stratigraphic units encountered. The physical properties of these units were determined from geotechnical samples from boreholes 699-48-77A and 699-48-77B, and analyses of core samples from boreholes $\mathrm{DH}-6, \mathrm{DH}-2$, and $\mathrm{DH}-13$. Physical analyses are summarized in WHC (1993).

\subsubsection{Hanford Formation}

The Hanford formation is $7 \mathrm{~m}(23 \mathrm{ft})$ thick and consists predominantly of open-framework gravels with a sandy matrix typical of deposits of the grave1dominated facies. A thin silt lens occurs at the base of the gravel sequence above the Plio-Pleistocene and early "Palouse" interval. The Hanford formation thickens both to the north and south of the site.

\subsubsection{Plio-Pleistocene Unit and Early "Palouse" Soll}

The combined thickness of the Plio-Pleistocene unit and early "Palouse" soll is $13 \mathrm{~m}$ (42 ft), with the depth interval ranging from $7 \mathrm{~m}(23 \mathrm{ft}$ ) to $19.8 \mathrm{~m}(65 \mathrm{ft})$. The upper portion probably correlates to the early "Palouse" soil, but because of the method of drilling, no attempt is made to separate 
Figure 6. Stratigraphic Units and Lithology Penetrated at the Proposed State-Approved Land Disposal

Structure by Borehole 699-48-77A.

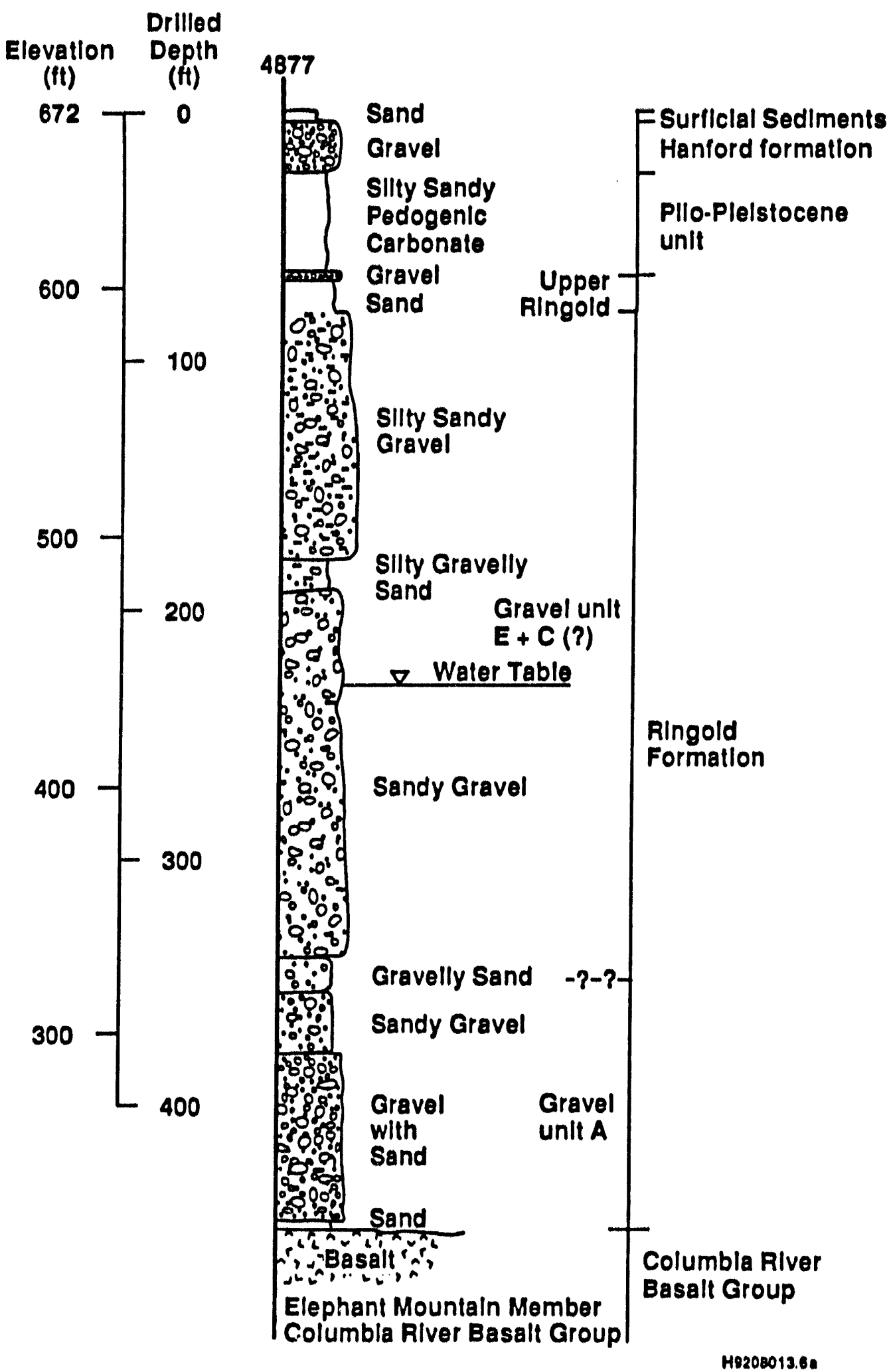


the early "Palouse" soll from the Plio-Plelstocene unit. The combined Plio-Pleistocene and early "Palouse" interval consists of interfingering carbonate-cemented silt, sand and gravel, and carbonate-poor silt and sand (WHC 1993). Thin pedogenic calclum carbonate lenses occur throughout the unit at the following horizons: $8.8 \mathrm{~m}(29 \mathrm{ft}) ; 8.96$ to $9.24 \mathrm{~m}(29.4$ to $30.3 \mathrm{ft})$; $10.8,10.9,16.3,18.37-18.44 \mathrm{~m}(35.3,35.8,53.5,60.3-60.5 \mathrm{ft})$; and minor caltche between 19.2 and $19.47 \mathrm{~m}(63.0$ and $63.9 \mathrm{ft})$. Some cemented sands occur in the unit also.

\subsubsection{Ringold Formation}

The Ringold Formation is $119 \mathrm{~m}(390 \mathrm{ft})$ thick in the borehole and is dominated by the gravel sequences. The Ringold Formation begins at $19.8 \mathrm{~m}$ $(65 \mathrm{ft})$ drilled depth and continues to the top of the CRBG at $138.7 \mathrm{~m}$ $(455 \mathrm{ft})$. A major cataclysmic flood channelway that is incised into the Ringold Formation occurs approximately $1 \mathrm{~km}$ north of the site. As a result of significant flood erosion in this channelway, the Plio-Pleistocene and early "Palouse" interval, the upper Ringold unit, and a large part of Ringold unit $E$ have been removed. The channelway is filled with approximately $45.7 \mathrm{~m}$ $(150 \mathrm{ft})$ of Hanford formation gravel-dominated deposits. The exact position of the erosional channelway edge is not known because no boreholes penetrate deep enough in the area between 699-51-75 (located within the channelway) and the SALDS to encounter it.

The sandy sequence that occurs between the base of the Plio-Pleistocene and early "Palouse" interval (19.8-m [65-ft] depth) and the top of the uppermost Ringold gravels (unit E) (25.3-m [83-ft] depth) at the site is interpreted to be erosional remnants of the upper Ringold unit. These strata pinch out to the north, west, and east of the site (Lindsey 1991). The upper unit extends to the south into the northern part of the 200 West Area.

The upper unit grades quickly down into the gravels of unit $E$ at 25- to 26.5-m (83- to 87-ft) depth. These gravels extend to a depth of $93 \mathrm{~m}(305 \mathrm{ft})$ with silt content increasing below $51.8 \mathrm{~m}$ (170 ft). The next $12.2 \mathrm{~m}$ ( $40 \mathrm{fi}$ (drilled depths 108 to $96 \mathrm{~m}$ [355 to $315 \mathrm{ft}$ ]) consists largely of sand wit a significant gravel and silt component. Studies of analogous outcrops sugycic that strata similar to this interval are characterized by gravels interbedded in sands. These deposits are underlain by $12.2 \mathrm{~m}$ (40 ft) (drilled depths 120 to $108 \mathrm{~m}$ [395 to $355 \mathrm{ft}]$ ) of sandy gravels that in turn overlie $17.3 \mathrm{~m}(57 \mathrm{ft})$ (drilled depths 138 to $120 \mathrm{~m}$ [452 to $395 \mathrm{ft}$ ]) of gravels containing only minor sands. It is not clear if these gravels and those found throughout the Ringold Formation have an open framework texture, al though such deposits are rare in outcrops of typical Ringold gravels. The base of the Ringold is marked by a thin sandy unit (1 $\mathrm{m}[3 \mathrm{ft}]$ ) overlying the basalt.

The Ringold lower mud unit was not encountered in the borehole and is interpreted to pinch out to the south (Lindsey 1991). With the lower mud unit absent, gravel unit $E$ directly overlies gravel unit $A$, and it is not possible to differentiate the two units. However, if the top of unit $A$ is projected towards the site from borehole 299-W6-1, it would occur near the top of the sand-poor gravels at $120-m(395-\mathrm{ft})$ depth (WHC 1993). Consequently, much of the lower $18 \mathrm{~m}(60 \mathrm{ft})$ of the Ringold section at the site may be part of gravel unit $A$. 


\subsection{HYDROLOGY}

A detalled discussion of Hanford Site hydrogeology can be found in DOE (1988a, vol. 2, chapter 3); Gephart et a1. (1979); Graham et al. (1981); Graham et a1. (1984), Law et a 1. (1987); and Delaney et a 1. (1991). A summary of Hanford Site hydrogeology follows.

\subsubsection{Regional Setting}

The Hanford Site has a semiarid climate and recelves an average of $16 \mathrm{~cm}$ $(6.25 \mathrm{in}$.) of precipitation per year. Mean annual runoff is estimated to be approximately 3\% of the total precipitation. The remaining precipitation is assumed to be lost through evapotranspiration with a small component (perhaps less than 1\%) recharging the groundwater system (DOE 1988a).

Primary surface-water features associated with the Hanford Site are the Columbia River and its major tributarles, the Yakima, Snake, and Walla Walla rivers (see Figure 1). West Lake, about 10 acres in size and less than $1 \mathrm{~m}$ (3 ft) deep, is the only natural lake within the Hanford site (DOE 1988a). Wastewater ponds, cribs, and ditches assoclated with nuclear fuel processing and waste disposal activities are also present on the Hanford Site (Figure 7 ).

Recharge rates are suggested to range from near 0 to more than $10 \mathrm{~cm} / \mathrm{yr}$ (4 in./yr), depending on surface conditions (Gee 1987, Pp. 5.1-5.4). Smal1 recharge rates occur where fine-textured sediments and deep-rooted plants occur. The larger values are interpreted to occur in areas having a coarse graveliy surface and no vegetative cover.

Approximately one-third of the Hanford site is drained by the Yakima River system. Cold Creek and its tributary, Dry Creek, are ephemeral streams within the Yakima River drainage system. Both streams drain areas along the western part of the Yakima River. Surface flow, which may occur during spring runoff or after heavier-than-normal precipitation, infiltrates and disappears into the surface sediments.

The hydrogeology of the Pasco Basin is characterized by a multiaquifer system that consists of four hydrogeologic units that correspond to the upper three formations of the CRBG and the sediments overlying the basalts. The basalt aquifers consist of the tholelitic flood basaits of the CRBG and relatively minor amounts of intercalated fluvial and volcaniclastic sediments of the Ellensburg Formation. Confined zones in the basalt aquifers are present in the sedimentary interbeds and/or interflow zones that occur between dense basalt flows. The main water-bearing portions of the interflow zones are networks of interconnecting vesicles and fractures of the flow tops and flow bottoms (DOE 1988a). The sediments overlying the basalts or uppermost aquifer system consist of fluvial, lacustine, and glaciofluvial sediments. This aquifer is regionally unconfined and is contained largely within the Ringold Formation and Hanford formation. 
Figure 7. Areas of Artificial Recharge on the Hanford Site.

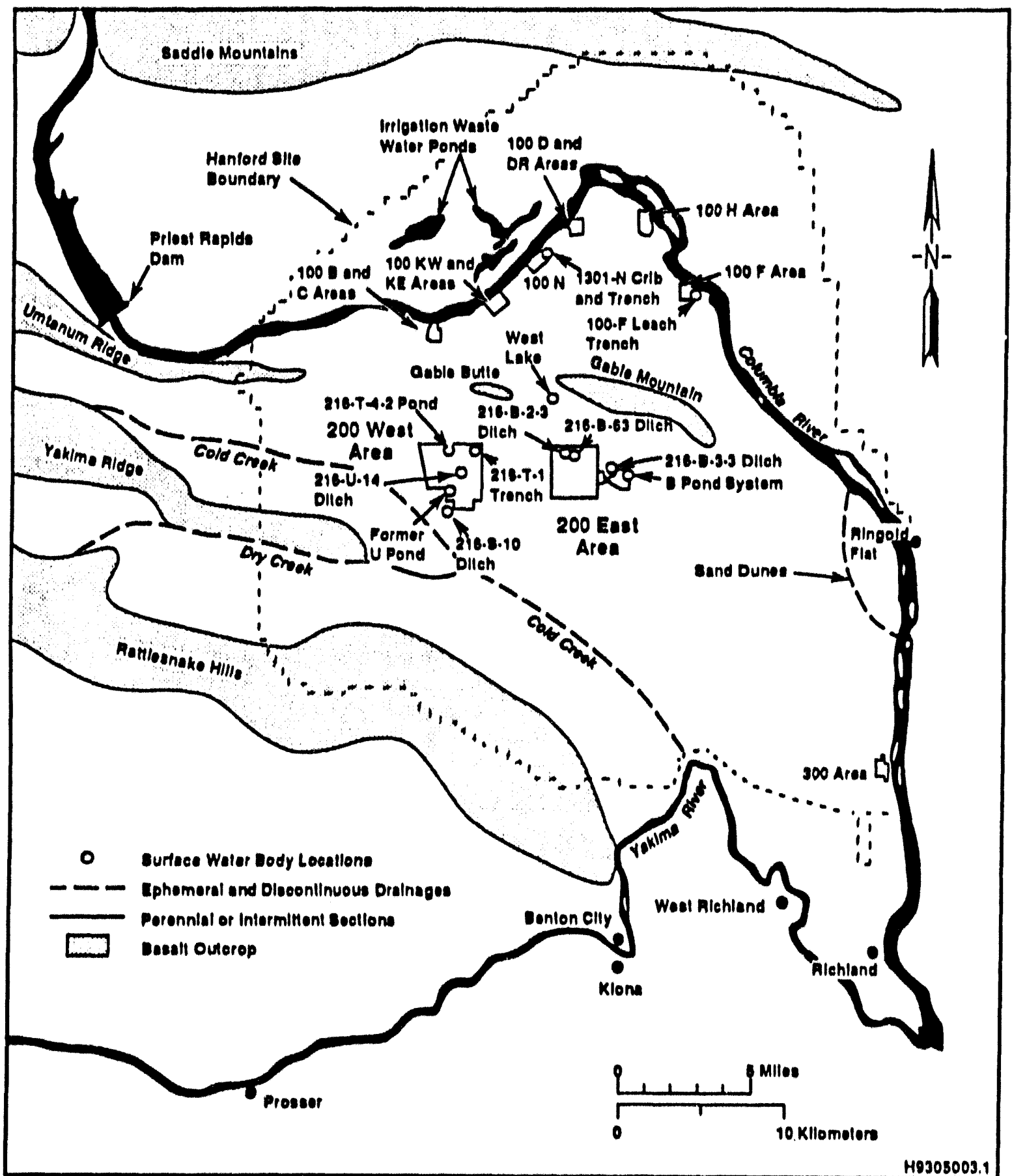




\subsubsection{Uppermost Aquifor System}

The uppermost aquifer system is unconfined reglonally beneath the Hanford site and 1 les at depths ranging from less than $0.3 \mathrm{~m}(1 \mathrm{ft})$ below ground surface near West Lake and the Columbla and Yakima rivers, to greater than $107 \mathrm{~m}(350 \mathrm{ft})$ in the central portion of the Cold Creek syncline. Groundwater in the aquifer system occurs within the glaclofluvial sands and gravels of the Hanford formation and the fluvial/lacustrine sediments of the Ringold Formation.

A water table contour map of the uppermost aquifer for the Hanford Site is shown in Figure 8 . The position of the water table in the western portion of the Hanford Site is generally within Ringold unit E gravels. In the eastern portion of the Hanford Site, the water table is generally within the Hanford formation. Hydraulic conductivitles for the Hanford formation $(601$ to $3,048 \mathrm{~m} /$ day $[2,000$ to $10,000 \mathrm{ft} / \mathrm{day}]$ ) are much greater than those of the gravel factes of the Ringold Formation (186 to $930 \mathrm{~m} /$ day $[610$ to $3,050 \mathrm{ft} / \mathrm{day}]$ ) (Graham et al. 1981). The matn body of the unconfined aquifer generally occurs within the Ringold Formation.

The base of the uppermost aquifer system is defined as the top of the uppermost basalt flow. However, fine-grained overbank and lacustrine deposits in the Ringold Formation locally form confining layers for Ringold fluvtal gravels underlying gravel unit $A$. The uppermost aquifer system is bounded iaterally by anticlinal basalt ridges and is approximately $152 \mathrm{~m}(500 \mathrm{ft})$ thick near the center of the Pasco Basin.

Sources of natural recharge to the uppermost aquifer system are rainfall and runoff from the higher bordering elevations, water infiltrating from small ephemeral streams, and river water along influent reaches of the Yakima and Columbia rivers. Discharge from the uppermost aquifer is primarily to the Columbla River (Graham et al. 1981, pp. 2-2 and 2-3).

Artificial recharge to the uppermost aquifer occurs principally from Hanford Site wastewater disposal practices at surface ponds, ditches, and various cribs within the 200 East and 200 West Areas. Two of the largest recharge mounds have developed beneath the 200 Areas at $U$ Pond and $B$ Pond (see Figure 7). Under $U$ Pond, which was decommissioned in 1985, the water table had risen in excess of $26 \mathrm{~m}(85 \mathrm{ft})$ since the start of disposal operations. The mound under B Pond has risen more than $9 \mathrm{~m}$ (30 ft) (Graham et al. 1981, p. 2-2). These facllities, associated with wastewater disposal from fuel and waste processing activities, receive or have received liquid effluents of varying chemical characteristics.

\subsubsection{Hydrology of the State-Approved Land Disposal Structure}

The hydrogeology of the site proposed for the SALDS was determined from examination of well logs and integration of these data with published hydrostratigraphlc correlations. Well 699-48-77A was drilled $122 \mathrm{~m}(400 \mathrm{ft})$ south of the SALDS site and was completed as a RCRA groundwater monitoring well with a 10-slot, $6-\mathrm{m}(20-\mathrm{ft})$ stainless steel screen installed between 64.7 and $70.8 \mathrm{~m}(212.4$ and $232.4 \mathrm{ft})$. 
Figure 8. Water Table at the Hanford Site.

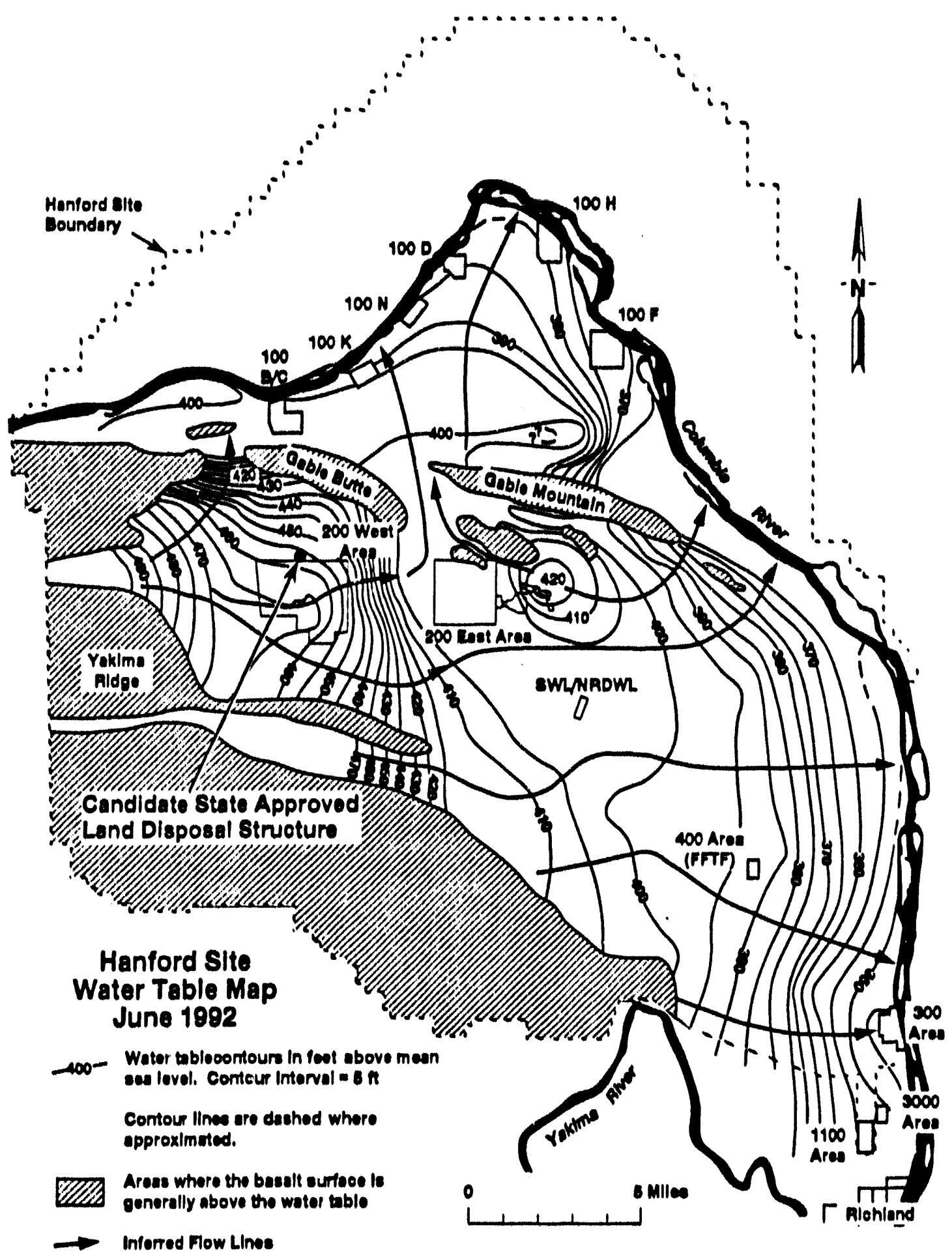

mesorod1.10 
The uppermost aquifer in the vicinity of the SALOS site is dominated by the fluvial gravels units $A$ and $E$ of the Ringold Formation. Because unit $A$ directly overlies unit $E$, the units cannot be differentlated. The water table was encountered in unit $E$ at about $66.6-\mathrm{m}(218.72-\mathrm{ft}) \mathrm{dr} 111$ ed depth (approximately $139 \mathrm{~m}$ [456 ft] above mean sea leve1). The saturated thickness of the $A$ and $E$ units combined is approximately $72 \mathrm{~m}(236 \mathrm{ft})$ under the SALOS site and overiles the basalt of the Elephant Mountain Member. An instantaneous slug test was performed on May 19, 1992. The results of this slug test are given in WHC (1993).

The unsaturated zone beneath the SALDS site is approximately $72 \mathrm{~m}$ $(236 \mathrm{ft})$ thick. Unsaturated sediments consist of the P110-Pleistocene/early "Palouse" solls and the gravel facles of the Hanford formation. At this location, the Plio-Pleistocene contains abundant calcium carbonate lenses throughout the unit.

2.4.3.1 Hydraulic Gradients. In the area of the proposed site, regional groundwater flow is generally from the west. Because of the mounding of the water table beneath U Pond to the south of the SALDS site, groundwater in the uppermost aquifer locally has diverged from its natural flow path. One component of flow is northeastward toward Gable Butte; a second coinponent is to the east-southeast, toward the Columbia River.

June 1992 groundwater elevations and representative flow paths for the unconfined aquifer in the SALDS site area are shown in Figure 9. Groundwater flow directions and hydraulic gradients generally are controlled by the mounding of the water table from effluent discharge to $U$ Pond. The water table map indicates that the hydraulic gradient in the vicinity of the SALDS site is on the order of 0.004 and the direction of groundwater flow is to the northeast. The potential impact of effluent mounding on the water table at the SALDS from facility operations has been addressed by WHC (1992b).

WHC (1992a) estimated groundwater travel times from the preferred SALDS to the Columbia River. Two cases were modelled, one with $B$ Pond in operation and one with B Pond not in operation. Their modeling suggested that groundwater would take approximately 134 years to reach the Columbia River with B Pond in operation and 126 years without B Pond in operation. The estimated standard error is $\pm 20 \%$.

2.4.3.2 Groundwater Quality. Upon completion of the borehole and well development, the groundwater from well 699-48-77A was sampled on June 19, 1992. This sampling is the first of four quarters of groundwater analyses that will provide prefacility baseline data (Harris and Delaney 1991). Historical groundwater quality in the vicinity of the SALDS has been previously reported by Harris and Delaney (1991).

Groundwater samples from the June 1992 sampling have been analyzed for the interim primary drinking water standards, the groundwater quality parameters, and the groundwater contamination indicator parameters spectfied 
Figure 9. Water Table Map for the Preferred State-Approved Land Disposal Structure and Vicinity.

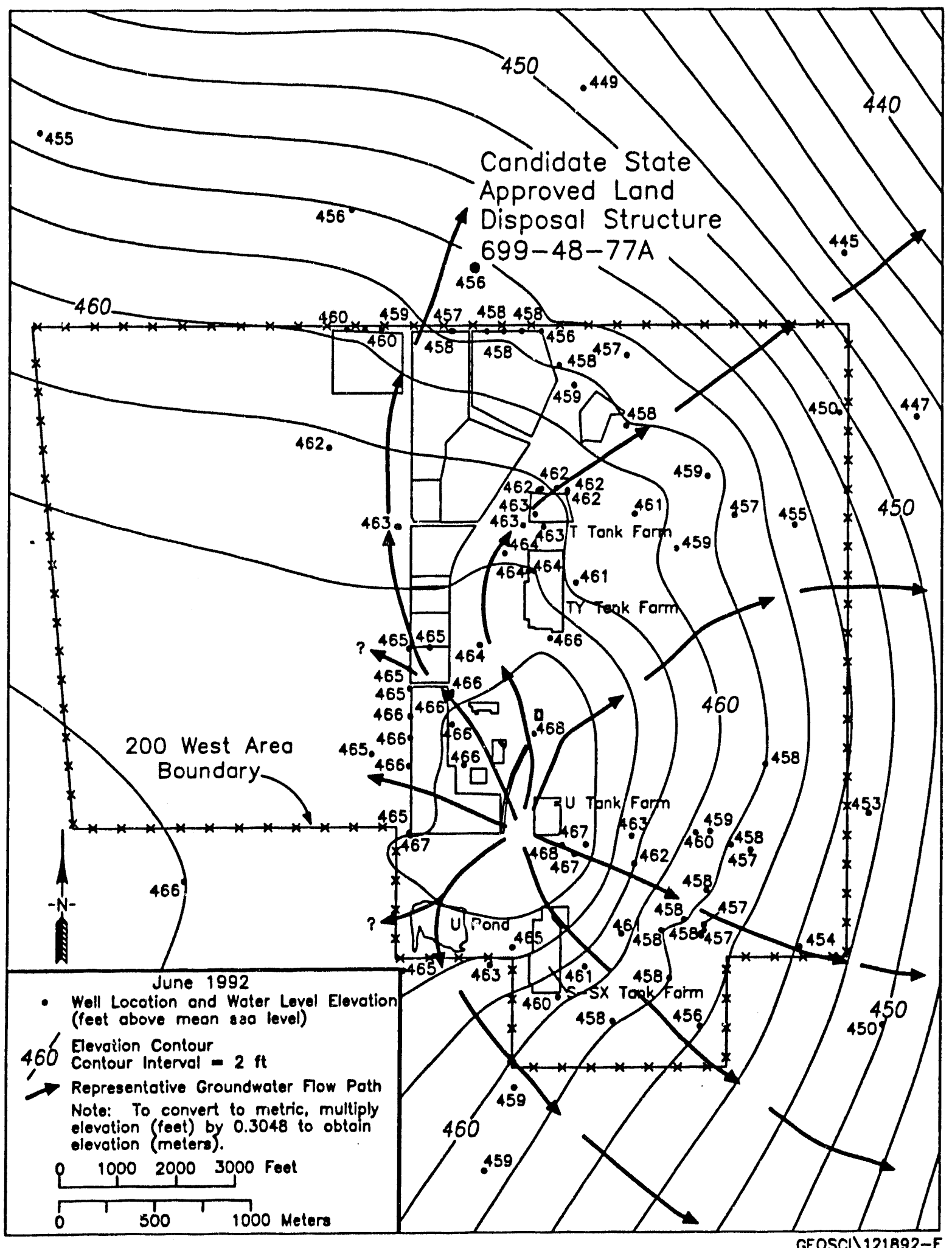


in Chapter 3.0. In addition, groundwater samples have been analyzed for tritium and a wide range of organic and inorganic constituents. In general, a long constituent list containing a large portion of the 40 CFR 264 Appendix IX 1 ist has been alternated to fit Hanford site conditions.

The results from this sampling are reported in Tables 2 and 3 . Table 2 is a listing of contamination indicator parameters used to evaluate groundwater analysis from the borehole. Table 3 reports the results of groundwater analyses between June 1992 and February 1993. All constituents were below detection 1 imits except coliform, nitrate, carbon tetrachloride, unfiltered iron, and unfiltered manganese. Filtered iron and filtered manganese are both below the detection limits. This suggests that the unfiltered values are an artifact of well construction. Nitrate is below the WAC 173-200 limit. Coliform was detected at $65 \mathrm{C} / \mathrm{dL}$ and is above the WAC 173-200 value of $1 \mathrm{C} / \mathrm{dL}$. Carbon tetrachloride was detected at $1.3 \mathrm{ppb}$, which is below the U.S. Environmental Protection Agency (EPA) standard of $5 \mathrm{ppb}$ but above the WAC 173-200 value of $0.3 \mathrm{ppb}$. The value for carbon tetrachloride is not quantifiable, however, because the contractually required quantitation limit is $5 \mathrm{ppb}$, which is above the result reported. During the next sampling period, carbon tetrachloride will be analyzed using a lower detection limit. This well will be sampled quarterly as part of the Hanford Groundwater Monitoring Program. After background detection is established, sampling will be on a semiannual basis. 
Table 2. Contamination Indicator Parameters Used for Borehole 699-48-77A. (5 sheets)

\begin{tabular}{|c|c|c|c|c|c|c|c|c|}
\hline \multicolumn{3}{|c|}{ Constituent name } & \multicolumn{3}{|c|}{ DWS } & \multicolumn{3}{|c|}{$\begin{array}{l}\text { Number of } \\
\text { samples }\end{array}$} \\
\hline $\begin{array}{c}\text { Short } \\
\text { (method) }\end{array}$ & Full & |Units & $\begin{array}{l}\text { Lab } \\
\text { CRQL }\end{array}$ & Limit & Agency & Total & |>CRQL & >DWS \\
\hline \multicolumn{9}{|c|}{ Contamination indicator parameters } \\
\hline CONDFLD & Conductivity, field & umhos & -- & 700 & WDOE & 1 & 1 & 0 \\
\hline TOC & Total organic carbon & ppb & 1000 & - & - & 1 & 0 & - \\
\hline TOXLDL & Total organic halogen & ppb & 10 & -- & -- & 1 & 1 & -- \\
\hline PH-FLD & pH, field & -- & -- & $6.5-8.5$ & EPAS & 1 & 1 & 0 \\
\hline \multicolumn{9}{|c|}{ Drinking water parameters } \\
\hline$A-B H C$ & Alpha-BHC & ppb & 0.05 & 4 & EPA & 1 & 0 & 0 \\
\hline ARSENIC & Arsenic & ppb & 5 & 50 & EPA & 1 & 0 & 0 \\
\hline FARSENI & Arsentc, flltered & Ppb & 5 & 50 & EPA & 1 & 0 & 0 \\
\hline BARIUM & Barium & ppb & 20 & 1000 & EPA & 1 & 1 & 0 \\
\hline FBARIUM & Barlum, filtered & ppb & 20 & 1000 & EPA & 1 & 1 & 0 \\
\hline b-BHC & Beta-BHC & $p p b$ & 0.05 & 4 & EPA & 1 & 0 & 0 \\
\hline CADMIUM & Cadmium & $p p b$ & 10 & 10 & EPA & 1 & 0 & 0 \\
\hline FCADMIU & Cadmium, filtered & ppb & 10 & 10 & EPA & 1 & 0 & 0 \\
\hline CHROMUM & Chromium & Ppb & 20 & 50 & EPA & 1 & 0 & 0 \\
\hline FCHROMI & Chromium, filtered & ppb & 20 & 50 & EPA & 1 & 0 & 0 \\
\hline$d-B H C$ & Delta-BHC & $\mathrm{ppb}$ & 0.1 & 4 & EPA & 1 & 0 & 0 \\
\hline ENDRIN & Endrin & Ppb & 0.1 & 0.2 & EPA & 1 & 0 & 0 \\
\hline FLUORID & Fluoride & $p p b$ & 100 & 4000 & EPA & 1 & 1 & 0 \\
\hline ALPHA & Gross alpha & $\mathrm{pCi} / \mathrm{L}$ & 4 & 15 & EPA & 2 & 1 & 0 \\
\hline BETA & Gross beta & $\mathrm{pCi} / \mathrm{L}$ & 8 & 50 & EPA & 2 & 1 & 0 \\
\hline LEAD & Lead & ppb & 5 & 50 & EPA & 1 & 0 & 0 \\
\hline FLEAD & Lead, filtered & ppb & 5 & 50 & EPA & 1 & 0 & 0 \\
\hline MERCURY & Mercury & Ppb & 0.2 & 2 & EPA & 1 & 0 & 0 \\
\hline FMERCUR & Mercury, filtered & ppb & 0.2 & 2 & EPA & 1 & 0 & 0 \\
\hline METHLOR & Methoxychlor & ppb & 2 & 100 & EPA & 1 & 0 & 0 \\
\hline SELENUM & Selentum & ppb & 10 & 10 & EPA & 1 & 0 & 0 \\
\hline FSELENI & Selentum, filtered & ppb & 10 & 10 & EPA & 1 & 0 & 0 \\
\hline
\end{tabular}


Table 2. Contamination Indicator Parameters Used for Borehole 699-48-77A. (5 sheets)

\begin{tabular}{|c|c|c|c|c|c|c|c|c|}
\hline \multicolumn{3}{|c|}{ Constituent name } & \multicolumn{3}{|c|}{ DWS } & \multicolumn{3}{|c|}{$\begin{array}{c}\text { Number of } \\
\text { samples }\end{array}$} \\
\hline $\begin{array}{l}\text { Short } \\
\text { (method) }\end{array}$ & Ful1 & Units & $\begin{array}{l}\text { Lab } \\
\text { CRQL }\end{array}$ & Limit & Agency & Total & $>C R Q L$ & $>$ DWS \\
\hline SILVER & silver & ppb & 20 & 50 & EPA & 1 & 0 & 0 \\
\hline FSILVER & Silver, filtered & $\mathrm{ppb}$ & 20 & 50 & EPA & 1 & 0 & 0 \\
\hline TOXAENE & Toxaphene & $\mathrm{ppb}$ & 2 & 5 & EPA & 1 & 0 & 0 \\
\hline LINDANE & Gamma-BHC (1 indane) & $\mathrm{ppb}$ & 0.05 & 4 & EPA & 1 & 0 & 0 \\
\hline \multicolumn{9}{|c|}{ Groundwater quality parameters } \\
\hline CHLORID & Chloride & ppb & 200 & 250000 & EPAS & 1 & 1 & 0 \\
\hline IRON & Iron & ppb & 20 & 300 & EPAS & 1 & 1 & 1 \\
\hline FIRON & Iron, filtered & $\mathrm{ppb}$ & 20 & 300 & EPAS & 1 & 0 & 0 \\
\hline MANGESE & Manganese & $\mathrm{ppb}$ & 10 & 50 & EPAS & 1 & 1 & 0 \\
\hline FMANGAN & Manganese, filtered & $\mathrm{ppb}$ & 10 & 50 & EPAS & 1 & 0 & 0 \\
\hline PHENOL & Phenol & $\mathrm{ppb}$ & 10 & -- & -- & 1 & 0 & -- \\
\hline SODIUM & Sodium & $\mathrm{ppb}$ & 300 & -- & -- & 1 & 1 & -- \\
\hline FSODIUM & Sodium, filtered & $\mathrm{ppb}$ & 300 & -- & -- & 1 & 1 & -- \\
\hline SULFATE & Sulfate & $\mathrm{ppb}$ & 500 & 250000 & EPAS & 1 & 1 & 0 \\
\hline \multicolumn{9}{|c|}{ Site-specific and other constituents } \\
\hline $1,1,1-\mathrm{T}$ & 1,1,1-Trichloroethane & $\mathrm{ppb}$ & 5 & 200 & EPA & 1 & 0 & 0 \\
\hline $1,1,2-T$ & 1,1,2-Trichloroethane & $\mathrm{ppb}$ & 5 & - & - & 1 & 0 & -- \\
\hline 1,1-DIC & 1,1-Dichloroethane & $\mathrm{ppb}$ & 5 & -- & -- & 1 & 0 & -- \\
\hline 1,2-DIC & 1,2-Dichloroethane & $\mathrm{ppb}$ & 5 & 5 & EPA & 1 & 0 & 0 \\
\hline 1,4-dben & 1,4-Dichlorobenzene & $\mathrm{ppb}$ & 5 & 750 & EPA & 1 & 0 & 0 \\
\hline BUTANOL & 1-Butanol & ppm & 1 & -- & -- & 1 & 0 & -- \\
\hline 2METHPH & 2-Methylphenol & $\mathrm{ppb}$ & 10 & - & -- & 1 & 0 & -- \\
\hline DDD & $4,4^{\prime}-D D D$ & $\mathrm{ppb}$ & 0.1 & -- & -- & 1 & 0 & -- \\
\hline DDE & $4,4^{\prime}-\mathrm{DDE}$ & $\mathrm{ppb}$ & 0.05 & - & - & 1 & 0 & -- \\
\hline DDT & $4,4^{\prime}-\mathrm{DDT}$ & $\mathrm{ppb}$ & 0.1 & - & - & 1 & 0 & -- \\
\hline MIBK & 4-Methy1-2-pentanone & $\mathrm{ppb}$ & 50 & - & - & 1 & 0 & -- \\
\hline 4METHPH & 4-Methylphenol & $\mathrm{ppb}$ & 10 & - & -- & 1 & 0 & - \\
\hline ACETONE & Acetone & $\mathrm{ppb}$ & 100 & -- & -- & 1 & 0 & -- \\
\hline
\end{tabular}


Table 2. Contamination Indicator Parameters Used for Borehole 699-48-77A. (5 sheets)

\begin{tabular}{|c|c|c|c|c|c|c|c|c|}
\hline \multicolumn{3}{|c|}{ Constituent, name } & \multicolumn{3}{|c|}{ DWS } & \multicolumn{3}{|c|}{$\begin{array}{c}\text { Number of } \\
\text { samples }\end{array}$} \\
\hline $\begin{array}{c}\text { Short } \\
\text { (method) }\end{array}$ & Full & Units & $\begin{array}{l}\text { Lab } \\
\text { CRQL }\end{array}$ & Limit & Agency & Total & $>C R Q L$ & $>$ DWS \\
\hline ALDRIN & Aldrin & $p p b$ & 0.05 & -- & -- & 1 & 0 & -- \\
\hline ANTIONY & Ant imony & $\mathrm{ppb}$ & 200 & -- & -- & 1 & 0 & -- \\
\hline FANTIMO & Antimony, filtered & $\mathrm{ppb}$ & 200 & -- & -- & 1 & 0 & -- \\
\hline BENZENE & Benzene & $\mathrm{ppb}$ & 5 & 5 & EPA & 1 & 0 & 0 \\
\hline BERYLUM & Beryllium & $p p b$ & 3 & -- & -- & 1 & 0 & - \\
\hline FBERYLL & Beryllium, filtered & $\mathrm{ppb}$ & 3 & -- & -- & 1 & 0 & -- \\
\hline BROMIDE & Bromide & $\mathrm{ppb}$ & 500 & - & - & 1 & 0 & - \\
\hline CALCIUM & Calcium & $\mathrm{ppb}$ & 100 & -- & -- & 1 & 1 & -- \\
\hline FCALCIU & Calcium, filtered & $\mathrm{ppb}$ & 100 & -- & - & 1 & 1 & -- \\
\hline TETRANE & Carbon tetrachloride & $\mathrm{ppb}$ & 5 & 5 & EPA & 1 & 0 & 0 \\
\hline CHLOANE & Chlordane & ppb & 0.1 & 2 & EPAP & 1 & 0 & 0 \\
\hline CHLFORM & Chloroform & $\mathrm{ppb}$ & 5 & 100 & EPA & 1 & 0 & 0 \\
\hline COBALT & Cobalt & $\mathrm{ppb}$ & 20 & -- & -- & 1 & 0 & -- \\
\hline FCOBALT & Cobalt, filtered & ppb & 20 & -- & -- & 1 & 0 & -- \\
\hline COLI-MFT & $\begin{array}{l}\text { Coliforms, membrane } \\
\text { filter }\end{array}$ & $\mathrm{COL}$ & 1 & 1 & EPA & 2 & 2 & 2 \\
\hline COPPER & Copper & $\mathrm{ppb}$ & 20 & 1000 & EPAS & 1 & 0 & 0 \\
\hline FCOPPER & Copper, filtered & $\mathrm{ppb}$ & 20 & 1000 & EPAS & 1 & 0 & 0 \\
\hline CYANIDE & Cyanide & $\mathrm{ppb}$ & 20 & -- & -- & 1 & 0 & -- \\
\hline DECANE & Decane & $\mathrm{ppb}$ & 10 & - & -- & 1 & 0 & - \\
\hline DIELRIN & Dieldrin & $\mathrm{ppb}$ & 0.05 & -- & -- & 1 & 0 & -- \\
\hline DODECAN & Dodecane & $\mathrm{ppb}$ & 10 & -- & -- & 1 & 0 & -- \\
\hline ENDO1 & Endosulfan I & ppb & 0.1 & -- & -- & 1 & 0 & -- \\
\hline ENDO2 & Endosulfan II & $\mathrm{ppb}$ & 0.05 & -- & -- & 1 & 0 & -- \\
\hline ENDSFAN & Endosulfan sulfate & $\mathrm{ppb}$ & 0.5 & -- & - & 1 & 0 & -- \\
\hline ENDRALD & Endrin aldehyde & $\mathrm{ppb}$ & 0.2 & -- & -- & 1 & 0 & -- \\
\hline HEPTLOR & Heptachlor & $\mathrm{ppb}$ & 0.05 & 0.4 & EPAP & 1 & 0 & 0 \\
\hline HEPTIDE & Heptachlor epoxide & $\mathrm{ppb}$ & 1 & -- & -- & 1 & 0 & -- \\
\hline
\end{tabular}


Table 2. Contamination Indicator Parameters Used for Borehole 699-48-77A. (5 sheets)

\begin{tabular}{|c|c|c|c|c|c|c|c|c|}
\hline \multicolumn{3}{|c|}{ Constituent name } & \multicolumn{3}{|c|}{ DWS } & \multicolumn{3}{|c|}{$\begin{array}{l}\text { Number of } \\
\text { samples }\end{array}$} \\
\hline $\begin{array}{c}\text { Short } \\
\text { (method) }\end{array}$ & Ful1 & Units & $\begin{array}{l}\text { Lab } \\
\text { CRQL }\end{array}$ & Limit & Agency & Total & $>C R Q L$ & $>$ DWS \\
\hline HYDRAZI & Hydrazine & $\mathrm{ppb}$ & 30 & -- & -- & 1 & 0 & -- \\
\hline I-129LD & $\begin{array}{l}\text { lodine-129, low } \\
\text { detection }\end{array}$ & pCt $/ L$ & 1 & 1 & EPAR & 1 & 0 & 0 \\
\hline MAGNES & Magnesium & ppb & 100 & -- & -- & 1 & 1 & -- \\
\hline FMAGNES & Magnesium, filtered & ppb & 100 & -- & -- & 1 & 1 & -- \\
\hline METHONE & Methyl ethyl ketone & $\mathrm{ppb}$ & 100 & - & - & 1 & 0 & -- \\
\hline METHYCH & Methylene chloride & $p p b$ & 5 & -- & -- & 1 & 0 & -- \\
\hline NAPHTHA & Naphthalene & $\mathrm{ppb}$ & 10 & -- & -- & 1 & 0 & -- \\
\hline NICKEL & Nickel & $\mathrm{ppb}$ & 30 & -- & -- & 1 & 0 & -- \\
\hline FNICKEL & Nickel, filtered & $\mathrm{ppb}$ & 30 & -- & -- & 1 & 0 & -- \\
\hline NITRATE & Nitrate & $\mathrm{ppb}$ & 200 & 45000 & EPA & 1 & 1 & 0 \\
\hline NITRITE & Nitrite & $\mathrm{ppb}$ & 200 & 3300 & EPAP & 1 & 0 & 0 \\
\hline PENTCHP & Pentachlorophenol & $\mathrm{ppb}$ & 50 & 200 & EPAP & 1 & 0 & 0 \\
\hline PHOSPHA & Phosphate & $\mathrm{ppb}$ & 400 & -- & -- & 1 & 0 & -- \\
\hline POTASUM & Potassium & $\mathrm{ppb}$ & 300 & -- & -- & 1 & 1 & -- \\
\hline FPOTASS & Potassium, filtered & $\mathrm{ppb}$ & 300 & -- & -- & 1 & 1 & -- \\
\hline TMP_C & Temperature, field & Deg C & -- & -- & - & 1 & 1 & -- \\
\hline PERCENE & Tetrachloroethene & $p p b$ & 5 & 5 & EPAP & 1 & 0 & 0 \\
\hline TETRADE & Tetradecane & $\mathrm{ppb}$ & 10 & -- & -- & 1 & 0 & -- \\
\hline TAF & Tetrahydrofuran & ppb & 10 & -- & -- & 1 & 0 & -- \\
\hline TIN & Tin & $\mathrm{ppb}$ & 100 & -- & -- & 1 & 0 & -- \\
\hline FTIN & Tin, filtered & $\mathrm{ppb}$ & 100 & -- & -- & 1 & 0 & -- \\
\hline TOLUENE & Toluene & ppb & 5 & 2000 & EPAP & 1 & 0 & 0 \\
\hline TRIBUTPH & Tributyl phosphate & $\mathrm{ppb}$ & 10 & -- & -- & 1 & 0 & -- \\
\hline TRICENE & Trichloroethene & $\mathrm{ppb}$ & 5 & 5 & EPA & 1 & 0 & 0 \\
\hline TRITIUM & Tritium & $\mathrm{pCi} / \mathrm{L}$ & 500 & 20000 & EPA & 2 & 0 & 0 \\
\hline VANADUM & Vanadium & $\mathrm{ppb}$ & 30 & -- & -- & 1 & 0 & -- \\
\hline FVANADI & Vanadium, filtered & ppb & 30 & -- & -- & 1 & 0 & -- \\
\hline
\end{tabular}


Table 2. Contamination Indicator Parameters Used for Borehole 699-48-77A. (5 sheets)

\begin{tabular}{|c|l|c|c|c|c|c|c|c|}
\hline \multicolumn{3}{|c|}{ Constituent name } & \multicolumn{4}{c|}{ DWS } & \multicolumn{3}{c|}{$\begin{array}{c}\text { Number of } \\
\text { samples }\end{array}$} \\
\hline $\begin{array}{c}\text { Short } \\
\text { (method) }\end{array}$ & \multicolumn{1}{|c|}{ Full } & Units & $\begin{array}{c}\text { Lab } \\
\text { CRQL }\end{array}$ & Limit & Agency & Total & >CRQL & >OWS \\
\hline VINYIDE & Vinyl chloride & PPb & 10 & 2 & EPA & 1 & 0 & $1 \star$ \\
\hline XYLENE & Xylenes (total) & PPb & 5 & -- & -- & 1 & 0 & -- \\
\hline ZINC & Zinc & PPb & 10 & 5000 & WDOE & 1 & 1 & 0 \\
\hline FZINC & Zinc, f1ltered & PPb & 10 & 5000 & WDOE & 1 & 0 & 0 \\
\hline MCRESOL & m-Cresol & PPb & 10 & -- & -- & 1 & 0 & -- \\
\hline TRANDCE & $\begin{array}{l}\text { trans-1,2- } \\
\text { Dichloroethylene }\end{array}$ & PPb & 5 & 100 & EPAP & 1 & 0 & 0 \\
\hline
\end{tabular}

*CRQL is greater than DWS, so exceedance of DWS is undetermined.

CRQL - contractually required quantitation $11 \mathrm{~m} / \mathrm{t} / \mathrm{regulatory}$ standard

DWS - drinking water standard

EPA - U.S. Environmental Protection Agency, Maximum Contaminant Levels in 40 CFR 141

EPAP - U.S. Environmental Protection Agency, Proposed Maximum Contaminant Level Goals in 50 FR 46936

EPAR - U.S. Environmental Protection Agency, National Interim Primary

Drinking Water Regulations, Appendix IV, EPA-570/9-76/003

EPAS - U.S. Environmental Protection Agency, Secondary Maximum Contaminant Levels in 40 CFR Part 143

WDOE - Washington Department of Ecology, Additional Secondary Maximum Contaminant Levels in WAC 248-54. 


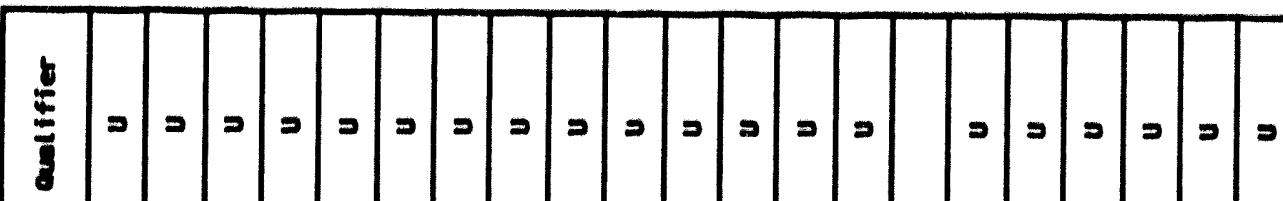

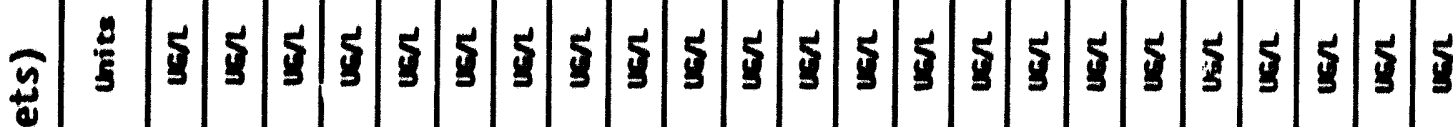

$\boldsymbol{\infty}$

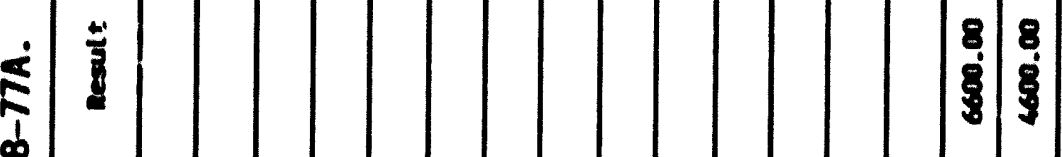

8

$\frac{0}{8}$

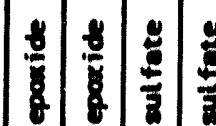

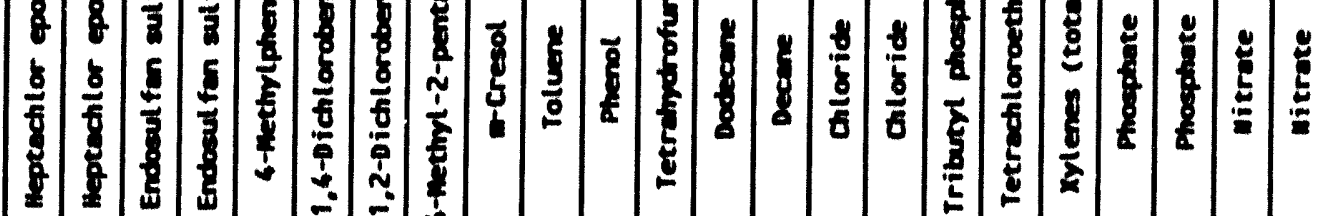

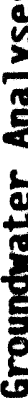

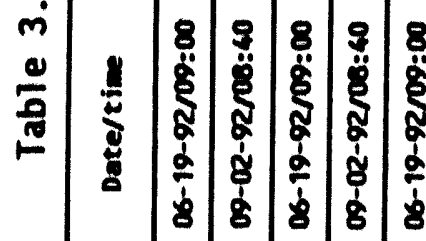

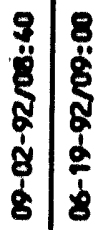

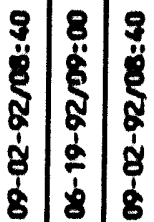

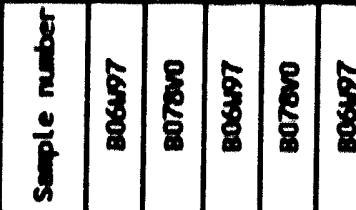

熙

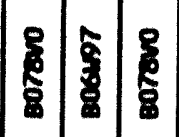




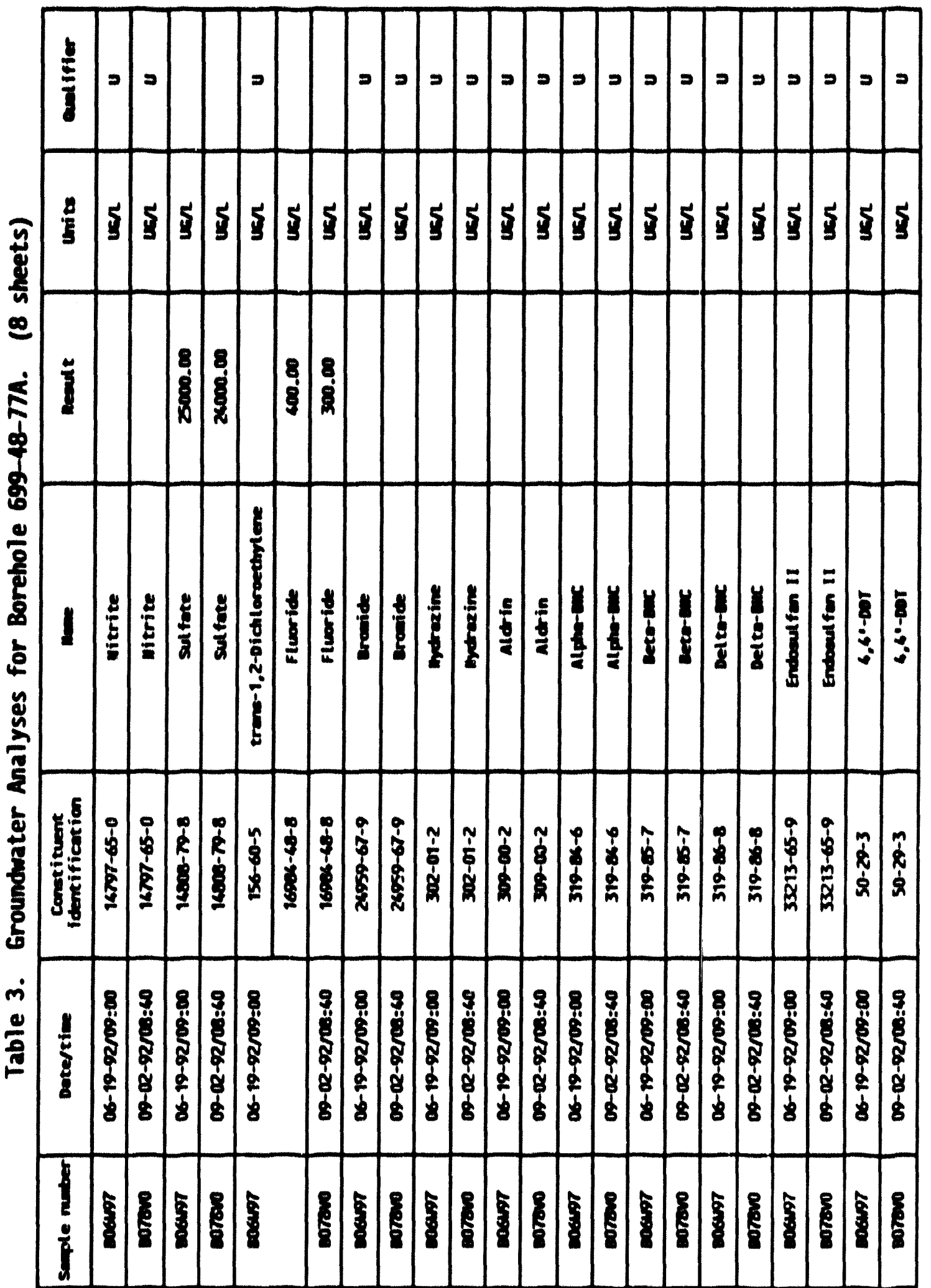




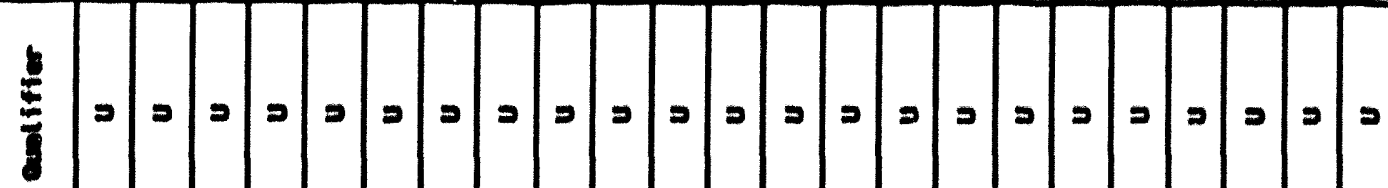

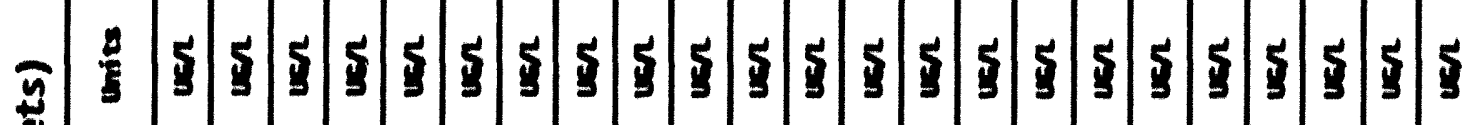

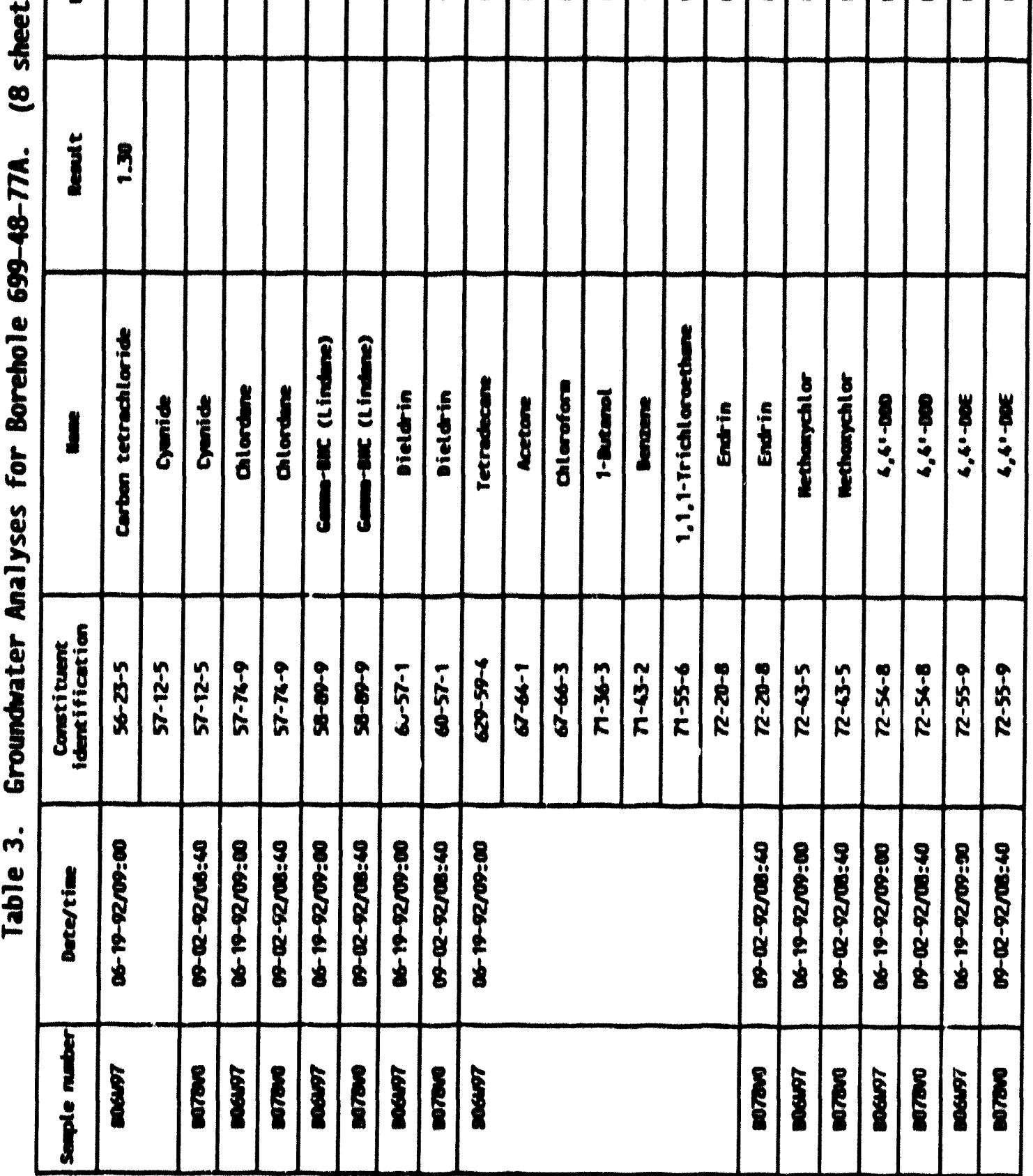




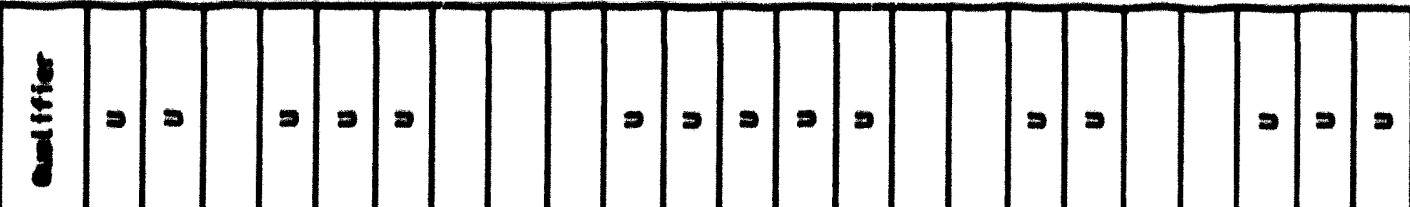

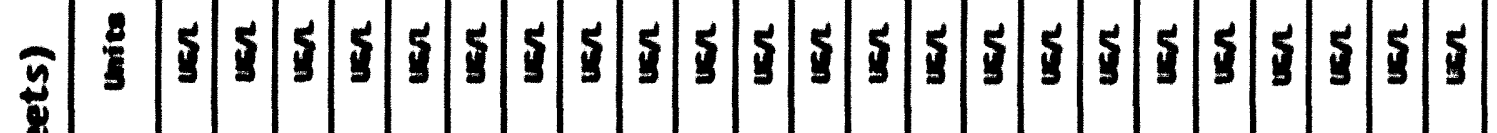

$\frac{1}{4}$

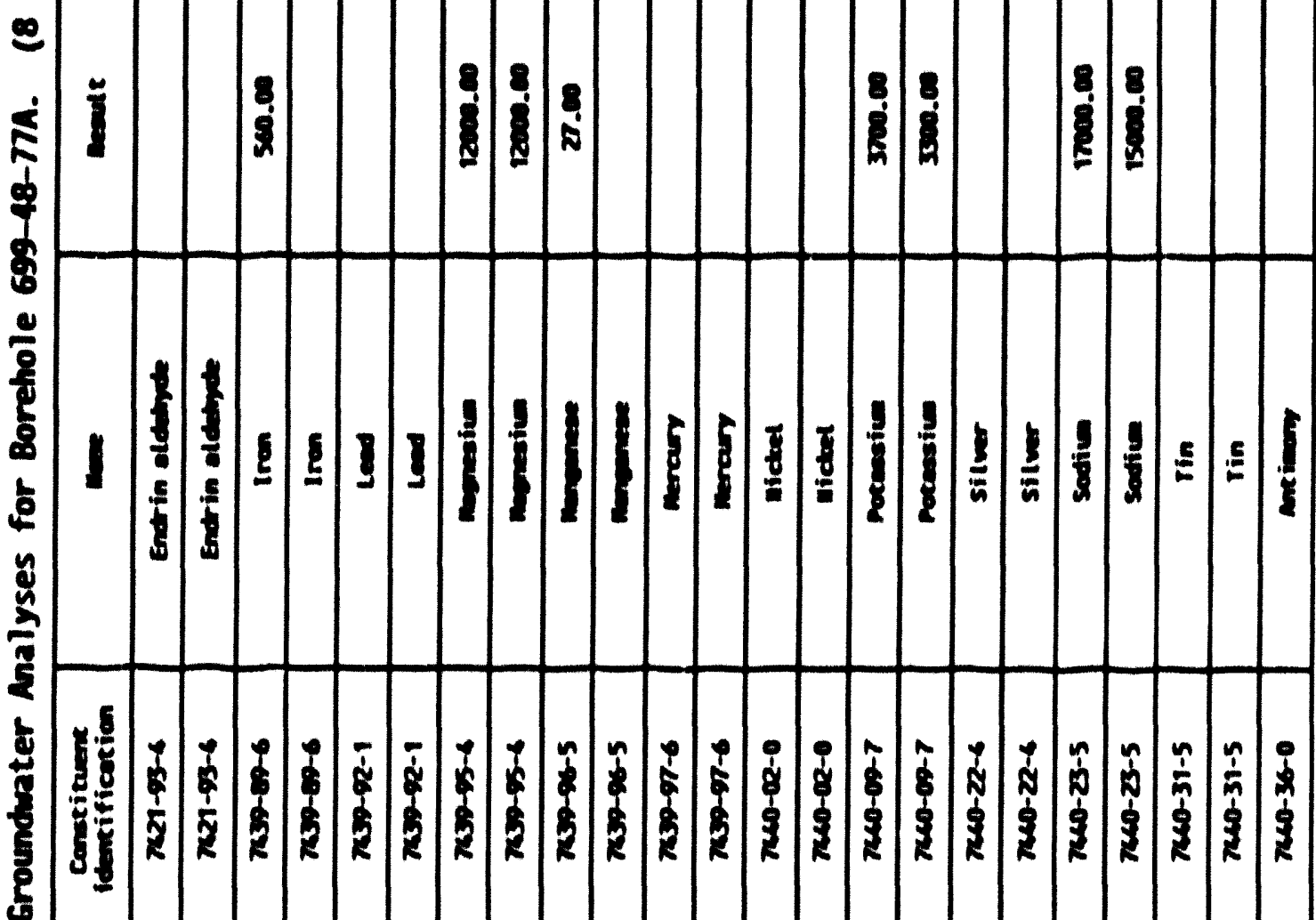

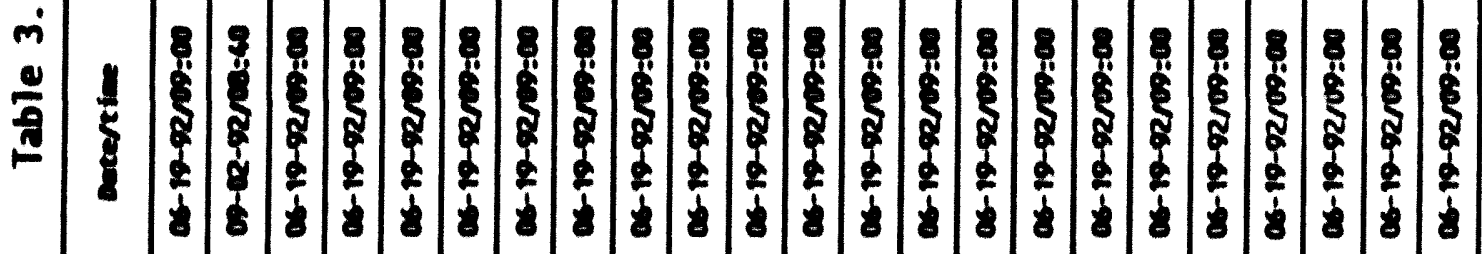

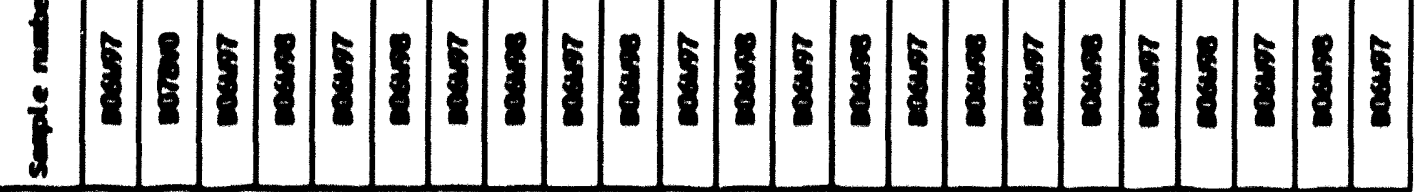




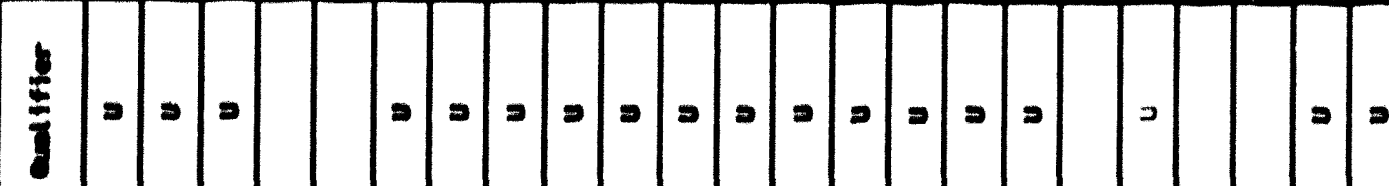

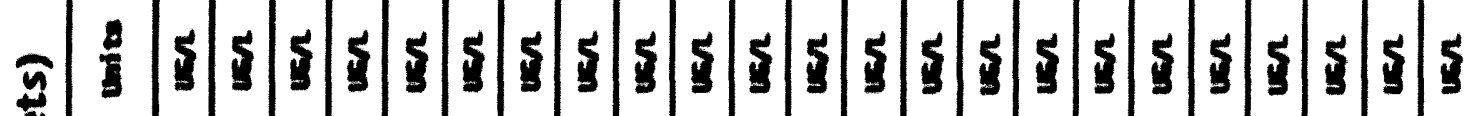

$\frac{8}{4}$

.

定

8

$\frac{8}{8}$

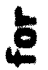

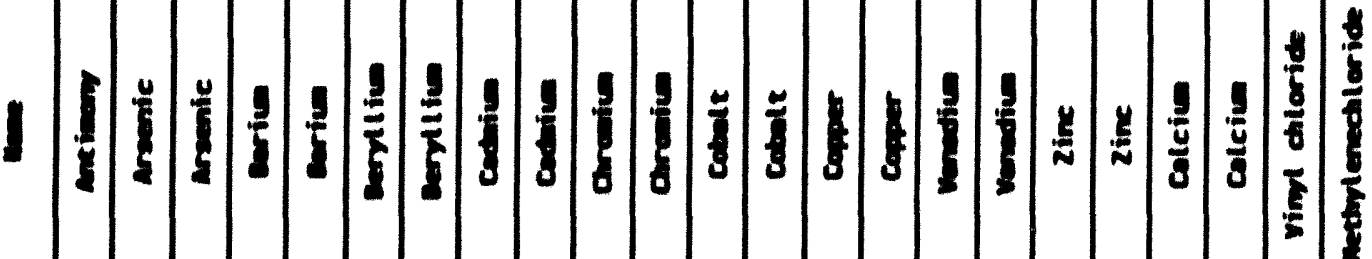

$\frac{n}{5}$

至

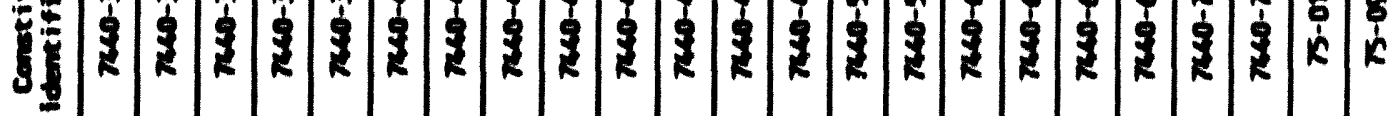

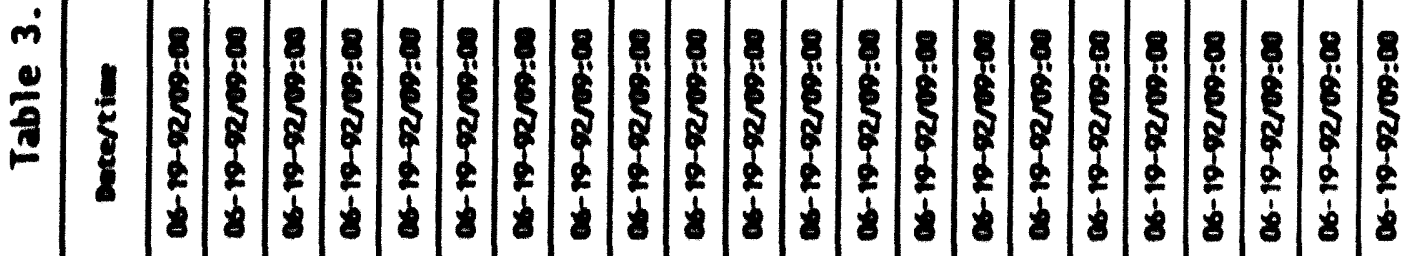

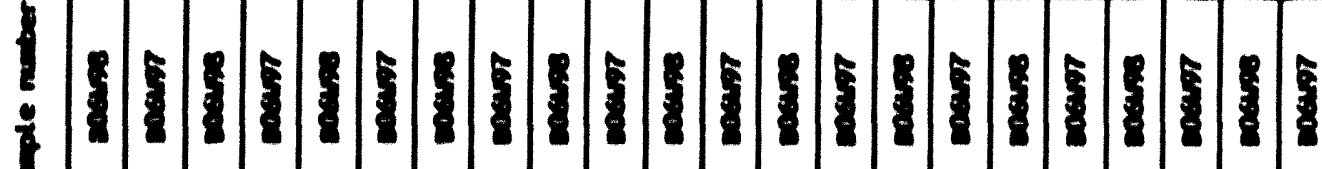




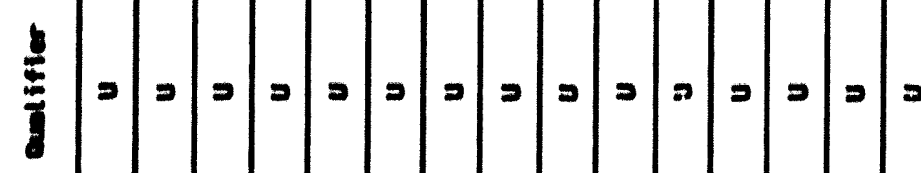

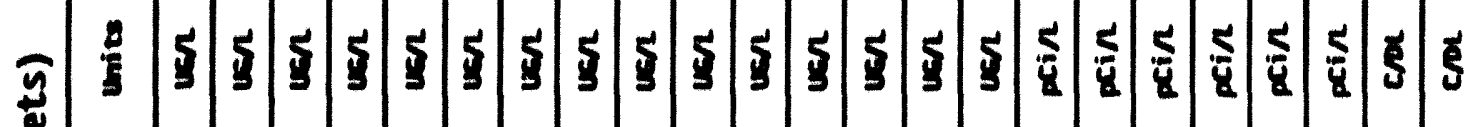

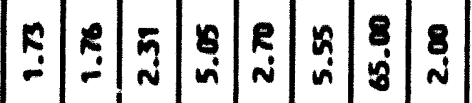

$\frac{\frac{c}{8}}{8}$

to

$\frac{m}{\frac{1}{n}}$

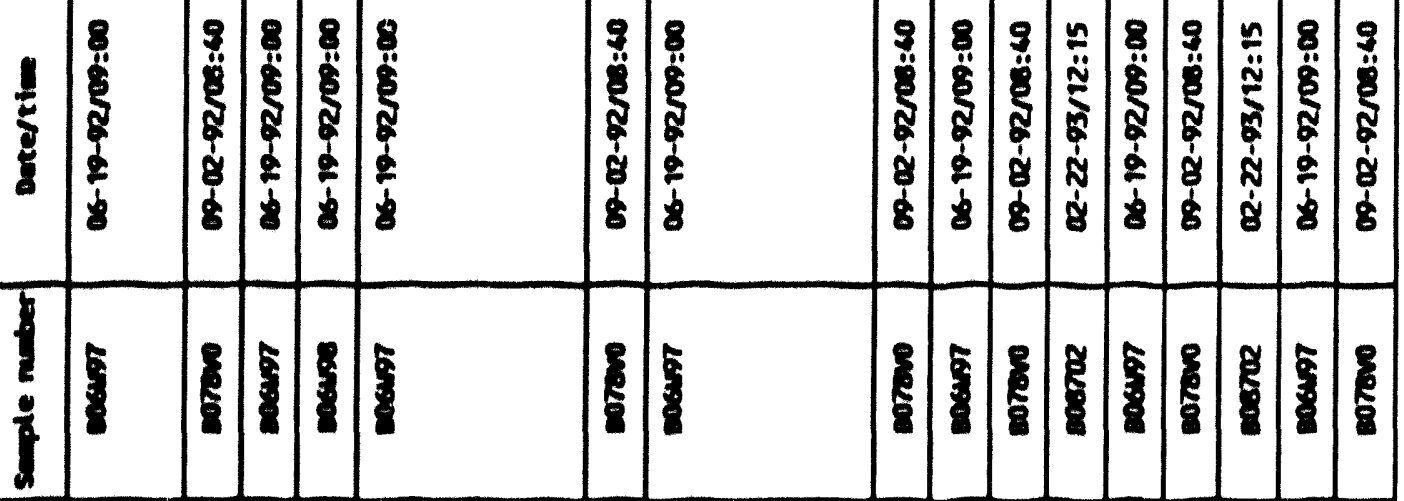




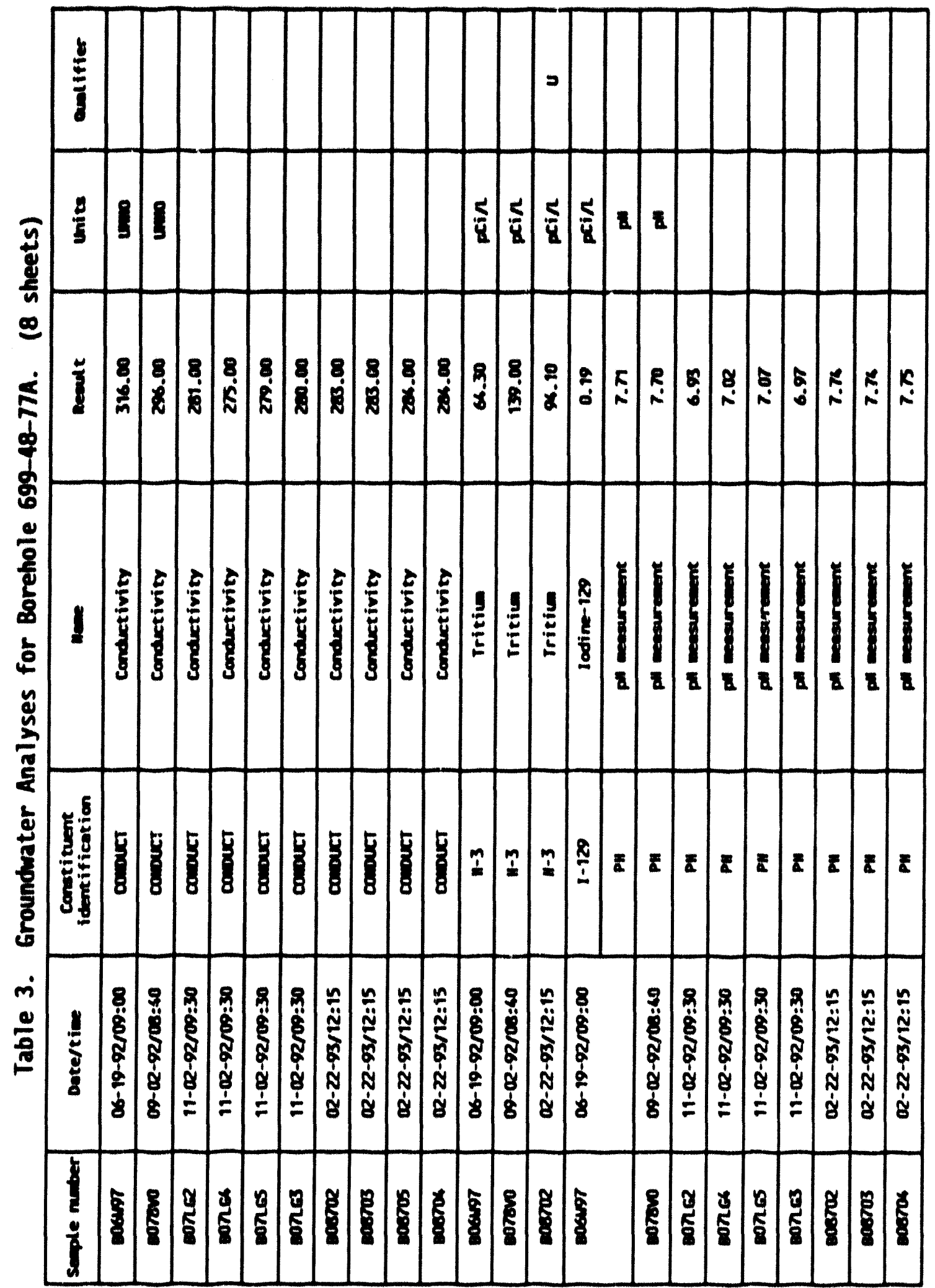




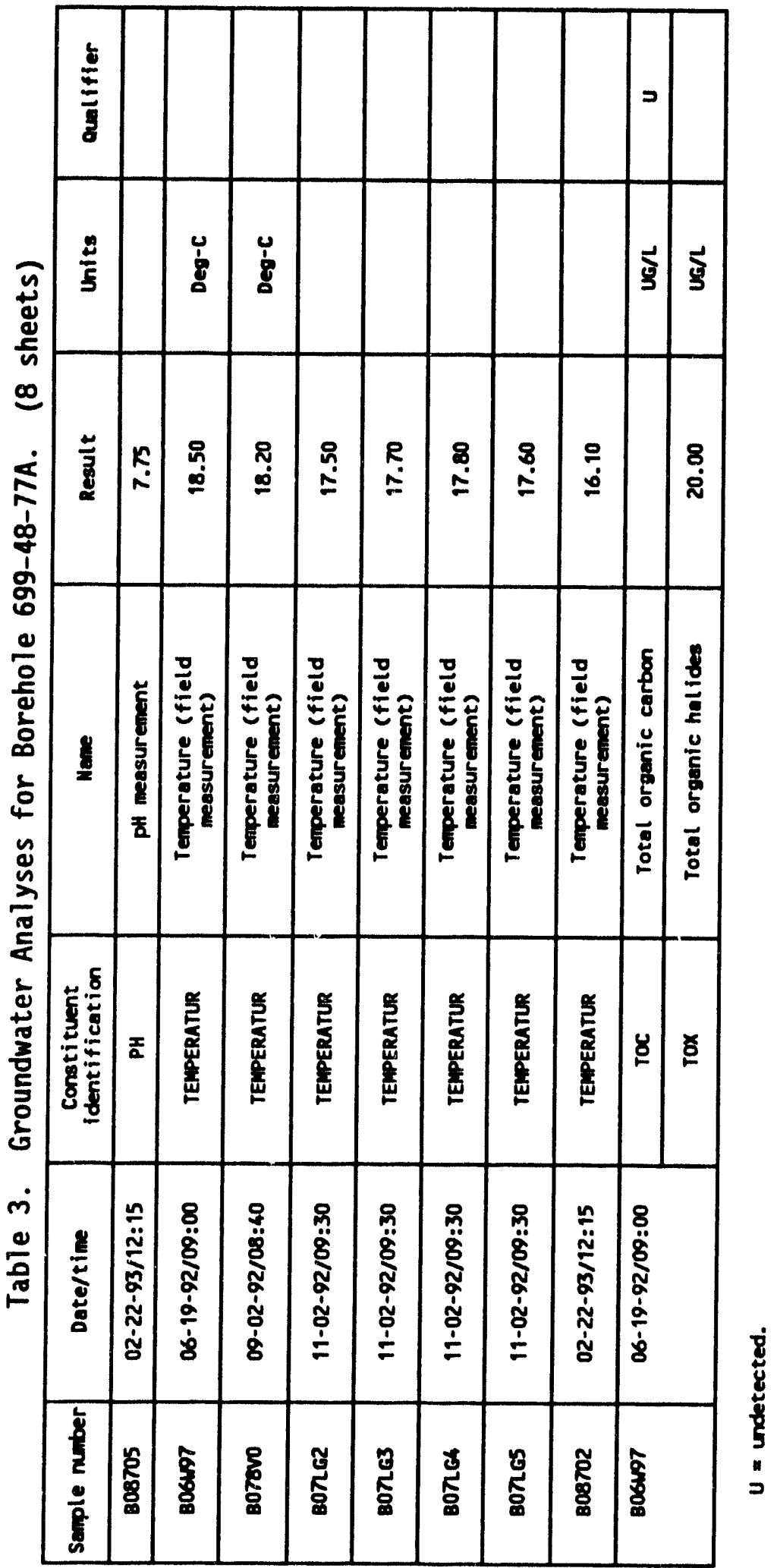


This page intentionally left blank. 


\subsection{PHASE I--GROUNDWATER MONITORING PROGRAM}

This plan has been developed in accordance with RCRA as described in 40 CFR 265, Subpart F, to estabi ish an interim-status detection-level groundwater monitoring program for the SALDS and, if necessary, to initiate a groundwater quality assessment program.

\subsection{OBJECTIVES}

The objectives of the drilling and groundwater monitoring program for the SALDS are as follow:

- Determine baseline groundwater quality for the SALDS before operation

- Prepare an outline for groundwater quality assessment for the SALDS.

This groundwater monitoring plan is designed to provide a program to provide detection-level monitoring at the site. It does not provide for the institutional controls for tracking tritium beyond the SALDS.

\subsection{APPROACH}

Two new groundwater monttoring wells will be installed to monitor the groundwater system downgradient from the SALDS (Figure 10). (Wel1 699-48-77A will be used as an existing upgradient groundwater monitoring well.) These wells will provide information to help characterize the hydrogeology at the site, and assess the three-dimensional hydraulic head distribution and groundwater flow directions. Also this will provide an indication of constituents that might migrate offsite from the SALDS.

Several existing groundwater monitoring wells located at the Low-Level Burial Ground factlity will be used to evaluate the hydrogeology and groundwater quality at the site (see Figure 2). These wells are located upgradient from the site and will assist in determination of groundwater quality unaffected by the site.

To evaluate hydrostratigraphy, subsurface sediment samples will be obtained during drilling at each location. These samples will be described and classified in the field, and selected samples will be submitted to a laboratory for analyses to determine various physical and chemical parameters. Groundwater samples will be collected during drilling in accordance with requirements of the Sample Analysis Plan. These samples will be analyzed for contamination indicator parameters (noted later in this section) before aquifer testing. If contamination is not detected above estabilished guidelines, aquifer tests will be conducted to provide estimates of transmissivity and hydraulic conductivity of sediments beneath the site.

Upon well completion, groundwater samples will be collected and analyzed quarterly from all new monttoring wells at the SALDS for the first five quarters and semiannualiy thereafter. Quarterly sampling of the existing 
Figure 10. Location of New Groundwater Monitoring Wells.

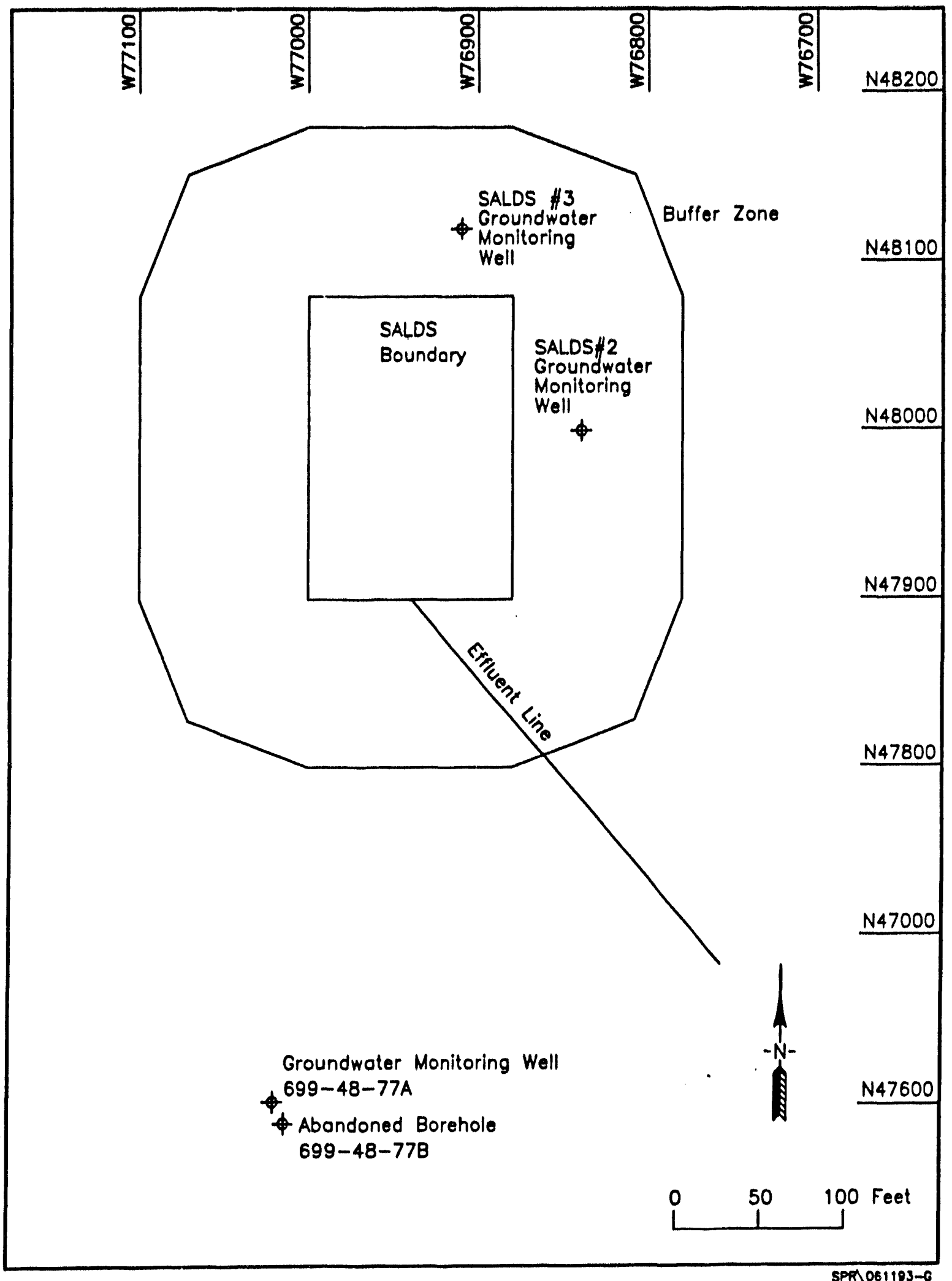


upgradient well started in June 1992 (Harris and Delaney 1991). This well, 699-48-77A, is currently on a quarterly sampling schedule.

\subsection{GROUNDWATER MONITORING SYSTEM}

This section defines the aquifer that will be monitored, the location and justification of the monitoring wells, how the new wells will be installed, what hydrogeologic data will be collected, the frequency of sampling, and the groundwater constituents to be analyzed.

\subsubsection{Uppermost Aquifer}

The uppermost aquifer beneath the SALDS is contained primarily within the unit $A$ and $E$ fluvial gravels of the Ringold Formation. The uppermost aquifer extends from the water table to the top of the Elephant Mountain Member and is discussed in more detail in Chapter 2.0. Hydrogeologic characterization activities are designed to obtain additional information on groundwater flow characteristics of the uppermost aquifer.

\subsubsection{New Characterization/Monitoring Wells}

Two new RCRA-compliant groundwater monitoring wells are planned for monitoring the SALDS (see Figure 10). Both wells will be located approximately $30 \mathrm{~m}(100 \mathrm{ft})$ downgradient from the site. The well coordinates are as follow:

\begin{tabular}{|c|c|}
\hline We11 & Location \\
\hline $\begin{array}{c}\text { SALDS \#2 } \\
(\text { we11 699-48-77C) }\end{array}$ & N48000 W76840 \\
\hline $\begin{array}{c}\text { SALDS \#3 } \\
(\text { we11 699-48-77D) }\end{array}$ & N48120 W76910 \\
\hline
\end{tabular}

Both wells will monitor only the upper portion of the uppermost aquifer. Well 699-48-77C will be drilled to the top of the Elephant Mountain Member (139 $\mathrm{m}[455 \mathrm{ft}]$ below ground surface) to define the thickness of the uppermost aquifer. The second well, 699-48-770, will be drilled $15 \mathrm{~m}(50 \mathrm{ft}$ ) below the water table. Both wells will be completed in the Ringold unit $E$ fiuvial gravels at a depth of approximately $73 \mathrm{~m}(240 \mathrm{ft})$ below ground surface, assuming a $6-\mathrm{m}(20-\mathrm{ft})$ screened interval is used. An existing groundwater monitoring we11 (699-48-77A) currently monitors groundwater quality upgradient of the SALDS.

\subsubsection{Justification for New Well Locations}

The additional groundwater monitoring wells are planned to complete the groundwater monitoring network at the SALDS. The addition of these wells is not necessarily intended to represent the final groundwater monitoring 
network. Additional monitoring wells may be required. The placement of any additional new wells will depend on results of water-level measurements, water-quality analyses, hydrogeologic information, and tracer tests collected from this initial monitoring network.

The two groundwater monitoring wells will be drilled in fiscal year 1993. In general, the purpose of the shallow wells at a site is to (1) provide upgradient and downgradient groundwater quality information for the upper portion of the uppermost aquifer, (2) provide a means of evaluating the hydraulic and flow properties of the uppermost aquifer, (3) provide information needed to refine subsurface stratigraphy beneath a facility, (4) provide samples to determine the moisture content of the unsaturated zone, and (5) provide samples to determine the vertical distribution of potential contaminants in the unsaturated and saturated sediments.

Specific justifications for the location and depth of the new monitoring wells at SALDS are as follow:

(1) Determine groundwater quality of the uppermost aquifer affected by the SALDS. The wells will be located downgradient of the site and will detect potential contaminants migrating from the site. Any potential contaminants are expected to occur in the upper part of the uppermost aquifer, therefore the screened interval will monitor this portion of the uppermost aquifer.

(2) Maximize monitoring 1ife of groundwater wells. A potential exists for future changes in groundwater flow direction with the decay of the existing groundwater mound associated with $U$ Pond. The direction of groundwater flow is expected to become more easterly in the future.

(3) Maximize monitoring efficiency of groundwater. A monitoring efficiency model was used to determine the optimum well locations to maximize monitoring efficiency of groundwater downgradient from the SALDS (Golder 1992). The monitoring efficiency model is based on the concept of the generation and growth of a plume as that plume migrates downgradient from a continuous source. The model shows where releases likely would and would not be detected. The planned downgradient monitoring well locations are based on $100 \%$ monitoring efficiency. The results of the tests for monitoring efficiency for four groundwater flow directions are shown in Figures 11 through 14, and summarized in Table 4.

Table 4. Monitoring Efficiency for Two Proposed Downgradient Wells.

\begin{tabular}{|c|c|}
\hline Groundwater flow direction & Monitoring efficiency \\
\hline N $20^{\circ} \mathrm{E}(70)$ & $99.2 \%$ \\
\hline N $30^{\circ} \mathrm{E}(60)$ & $98.8 \%$ \\
\hline N $40^{\circ} \mathrm{E}(50)$ & $98.7 \%$ \\
\hline N $50^{\circ} \mathrm{E}(40)$ & $97.5 \%$ \\
\hline
\end{tabular}


Figure 11. Groundwater Monitoring Well Efficiency for the State-Approved Land Disposal Structure Using a Hydraulic Gradient of $N 20^{\circ} \mathrm{E}$.

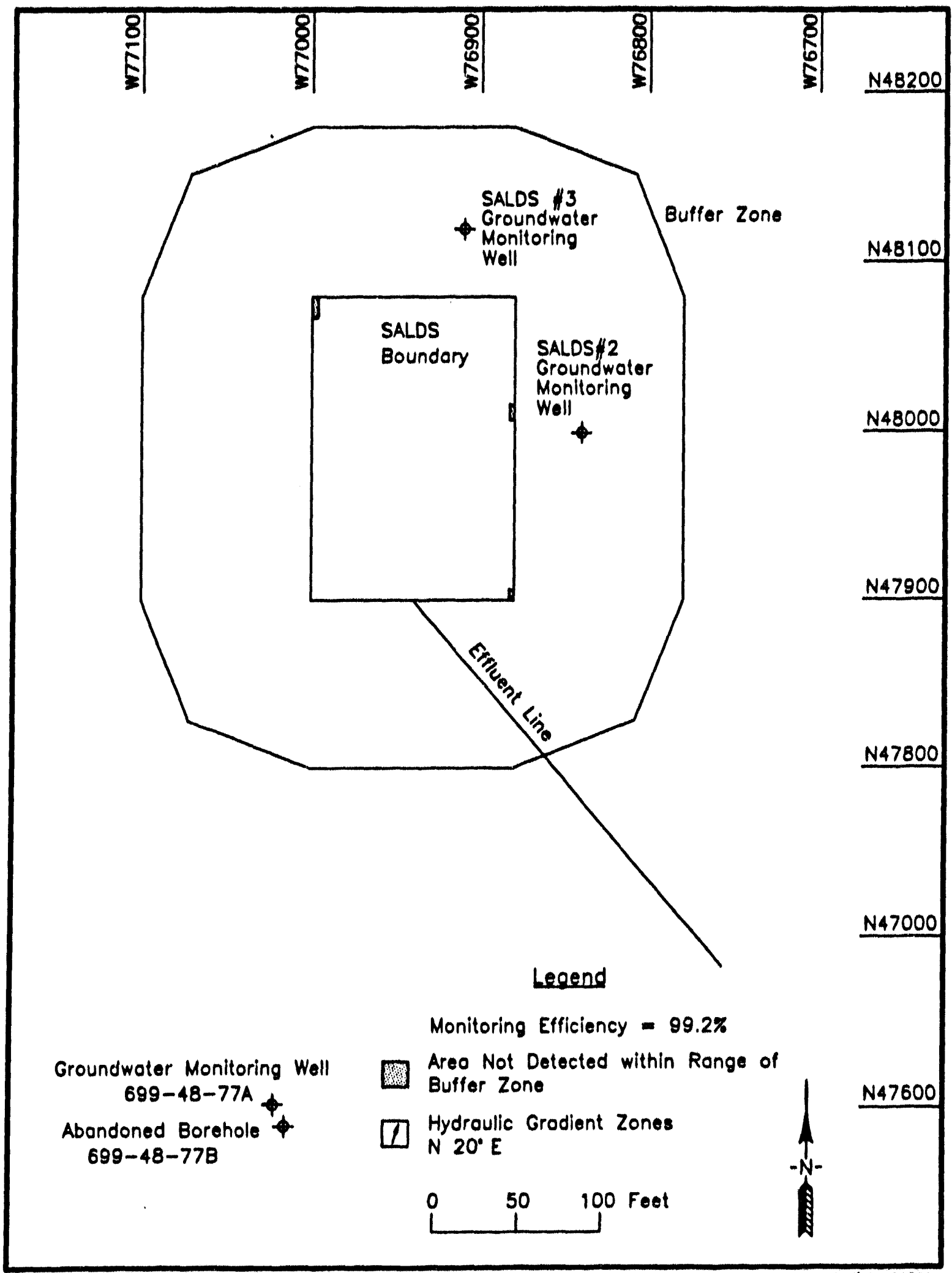

$\operatorname{sen} 0 \sin _{200301}$ 
Figure 12. Groundwater Monitoring Well Efficiency for the State-Approved Land Disposal Structure Using a Hydraulic Gradient of $N 30^{\circ} \mathrm{E}$.

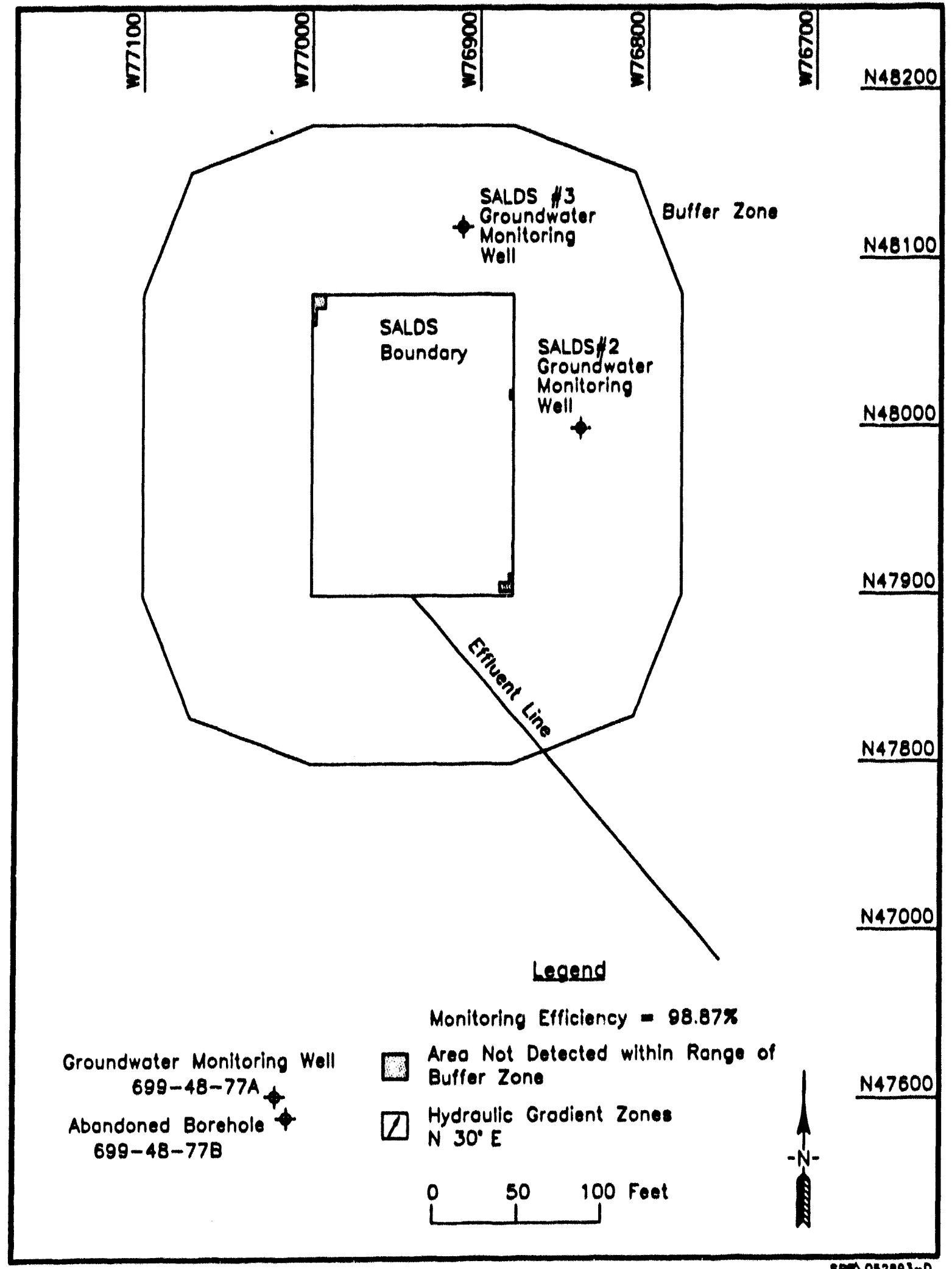

$\operatorname{sen} 082803-0$ 
Figure 13. Groundwater Monitoring Well Effictency for the State-Approved Land Disposal Structure Using a Hydraulic Gradient of $N 40^{\circ} \mathrm{E}$.

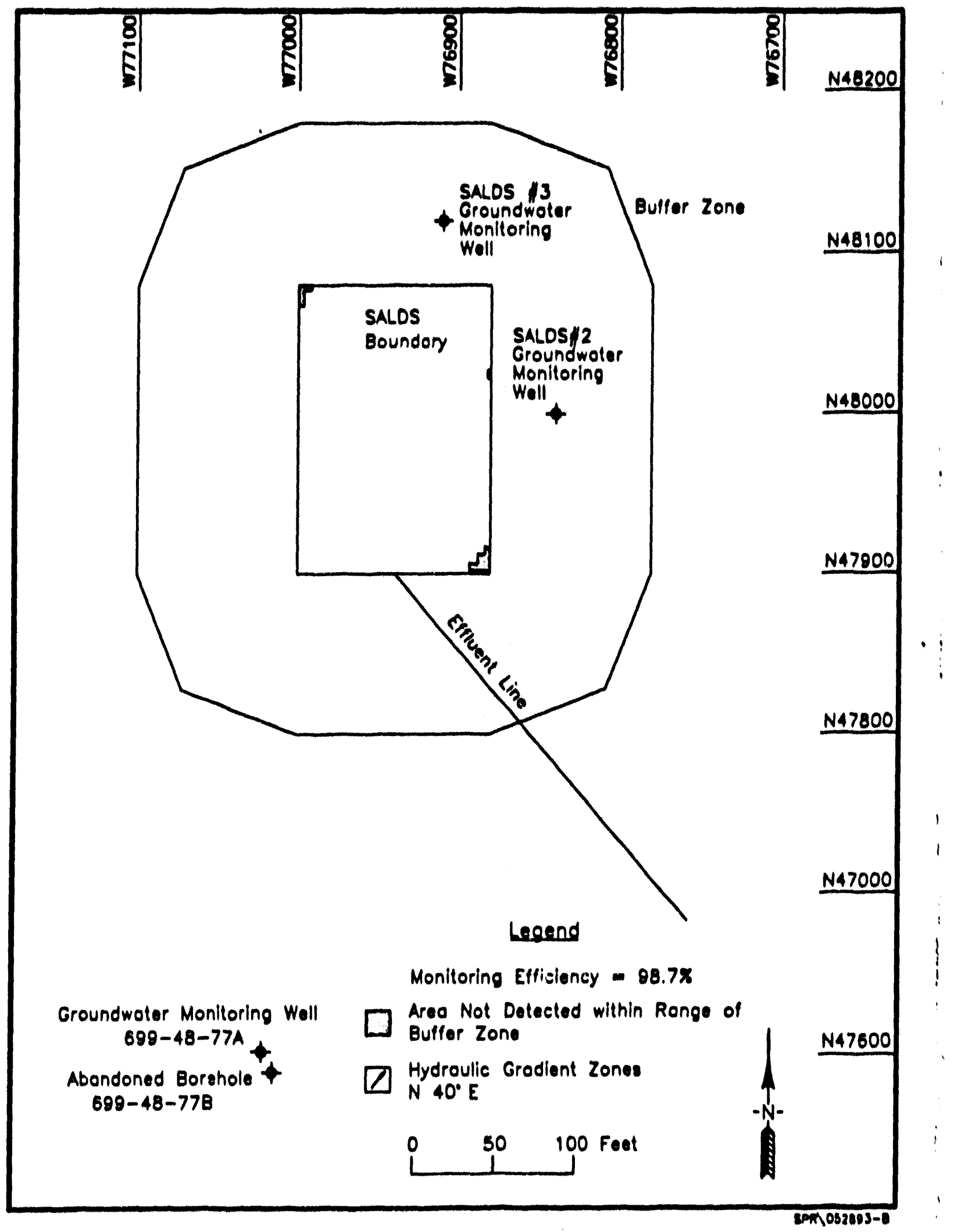


Figure 14. Groundwater Monitoring Well Effictency for the State-Approved Land Disposal Structure Using a Hydraulic Gradient of $N 50^{\circ} \mathrm{E}$.

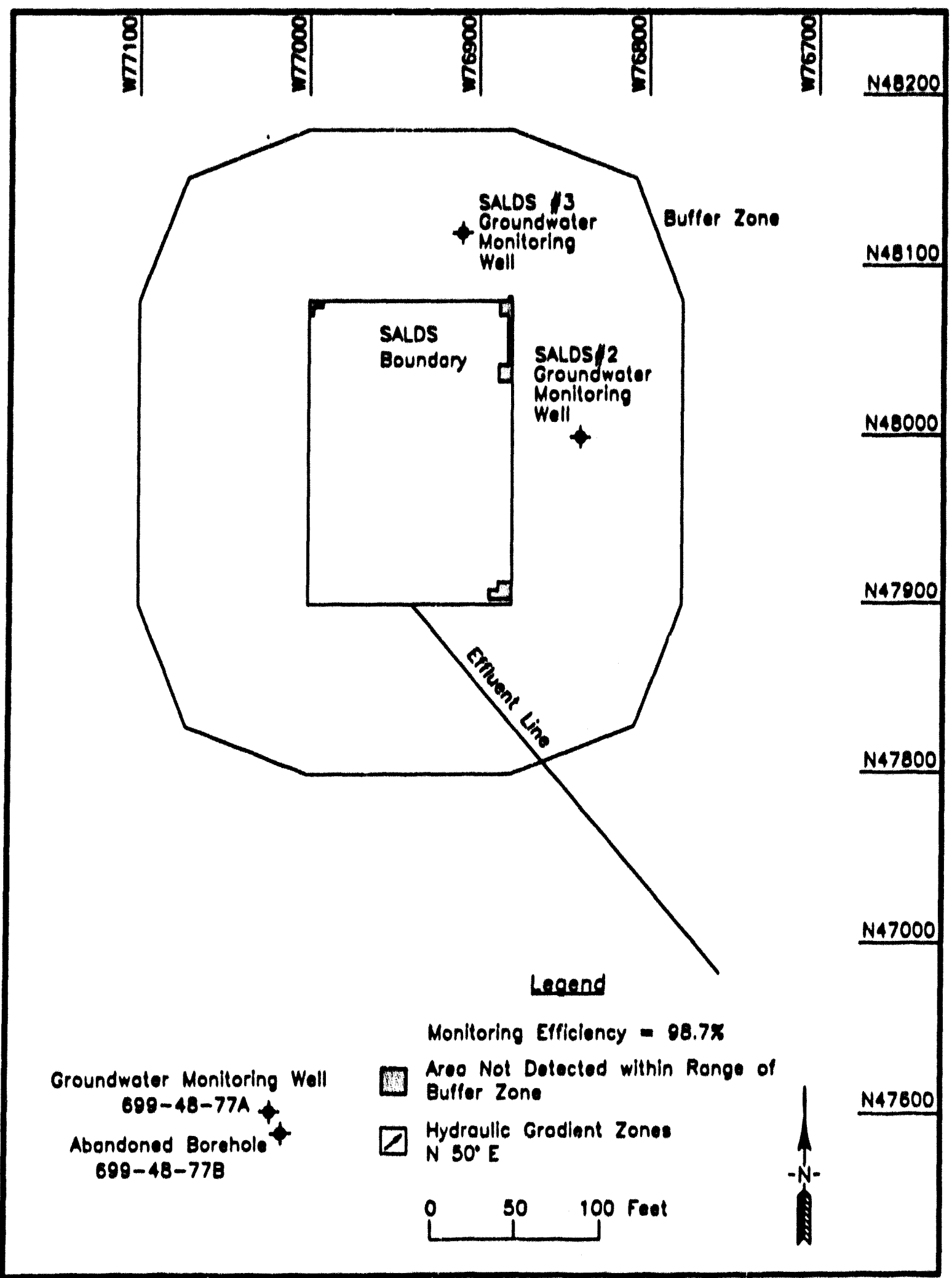


(4) Compliance with Manford site Aroundwater Protect ion Management Proprem. The Menford site Groundwater Protection Management Progran (DOE/RL 89-12 [DOE/RL 1989]) was devoloped to comply with DOE order 3400.1 (DOE 19886$)$. This groundwater monitoring plan is designed to make the SALDS comply with the overall objectives of that program (DOE/RL 89-12, D. II [DOE/RL 1989]) and the general strategy (PD. 13 and i1).

\subsubsection{Just1ftcation for Using Extsting Monttoring Mells}

To Justify use of the existing wells as part of the groundwater monitoring system for the SALDS, three aspects must be considered:

(1) whethor the wolls are adequately located, (2) whather the wells will provide samples that are representative of the groundwater, and (3) whether the structural integrity of each well is adequate.

It is proposed that the exlsting RCRA-compllant groundwater monitoring well, 699-48-77A, be used as the upgradient monitoring well. The SALDS location (see Flgure 10) within the proposed area, as dofined by Koeglor (1990), was situated with respect to this monitoring well so that the well could be used as the upgradient monitoring well. The location of the SALDS in Figure 10 was done using the monitoring effictency model of Golder (1992). The effective coverage of woll 699-48-77A as an upgradient monitoring weil based on the modeling rasults is 111 lustrated in floure 15 . Any contaminant passing through woll 699-48-77A has a downgradient occurrence probabllity as show in Figure 15. That 1s, well 699-48-77A has a 99x probability of detecting any contaminant that would spread downgradient in the area of the SALDS.

Eight existing RCRA groundwater monitoring wells are located $610 \mathrm{~m}$ $(2,000 \mathrm{ft}$ ) upgradient from the SALDS (Harrls and Delaney 1991 and Figure 2). These wells were drilled in 1987, 1988, and 1990, and monitor the Low-Level Burtal Grounds in the 200 East Area. Thesn wells are useful to monitor groundwater quality unaffected by the SALDS.

3.3.4.1 Woll Construction. Schematic dlagrams of completed shallow wells are presented in Figure 16. Procedures concerning geologle sampling and inspection of weil construction are given in WHC-CM-3-7. Environmental Investigations and site Characterization Manual. Guidance for designing the wells is obtained from WAC 173-160. Quality Assurance requirements of the Hanford Federal Facllity Agreement and Consent Order (Tri-Party Agreement) (Ecology et 21. 1989) and WHC-SD-EN-QAPP-001 (WHC 1992C) and WHC-S-014 (generle well specifications) also apply. If contamination is encountered that is determined to be significant enough to require changes in the well design or well location, Ecology will be notified.

The shallow wells will be completed with 10-cm (4-in.) inside diameter stainless steel casing, and cont inuous-slot well screens. Final woll screen length will be $6 \mathrm{~m}(20 \mathrm{ft})$ (4 m [15 ft] below the water table) for the shallow wells, if reguired. This placement will permit samping of the upper portion of the aquifer and will allow detection of any immiscible constituents that might be floating on the water table and any constituents in solution at the surface of the water table. It will al so allow for some fluctuitions of the 
Figure 15. Groundwater Monitoring Well Efficlency for Borehole 699-48-77A is an Upgradient Mell. (Shaded area shows the coverage of Borehole 699-48-77a if a Constltuent Were to Pass Through the Borehole.)

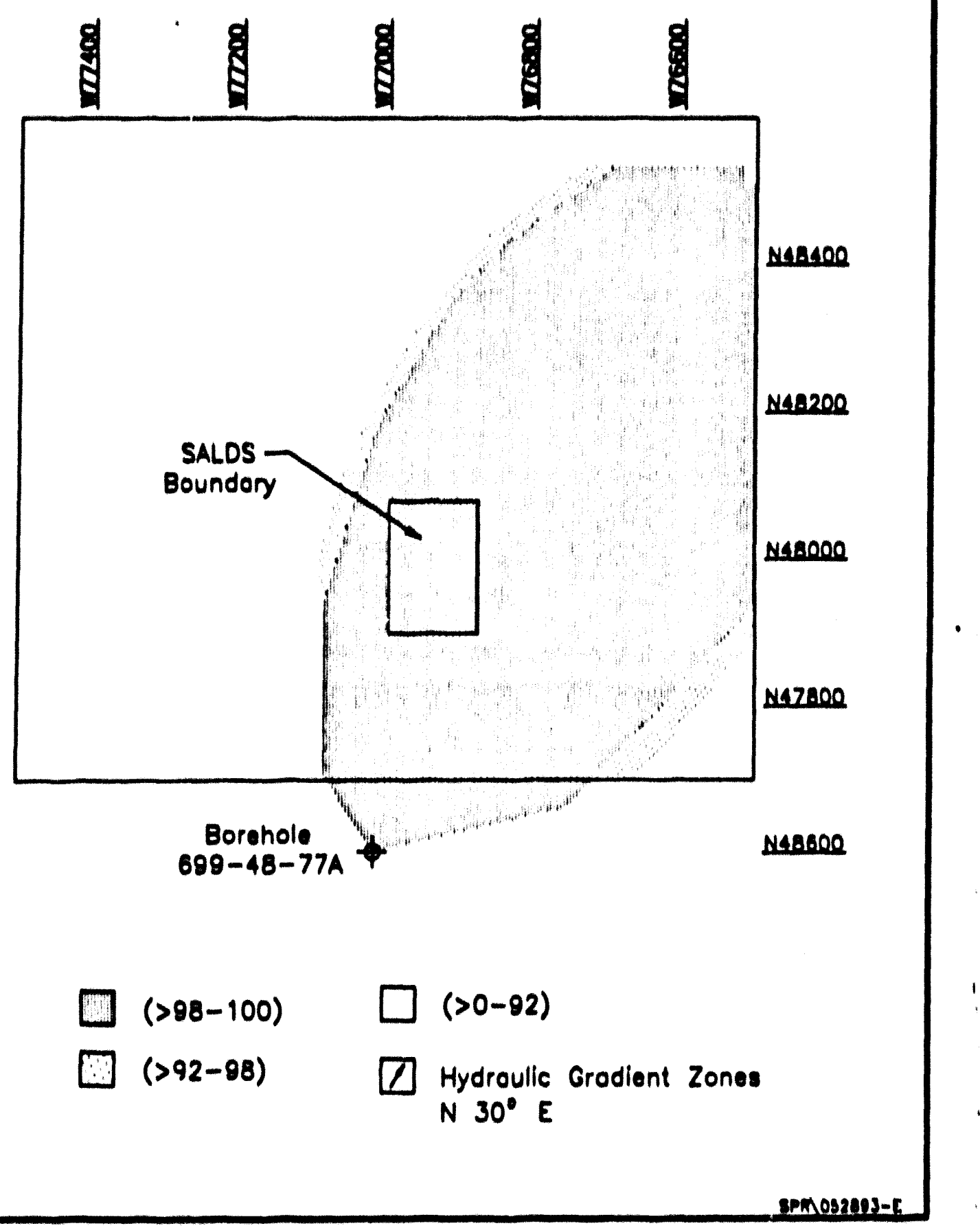


Figure 16. Schematic Diagrams of a Monitoring Well.

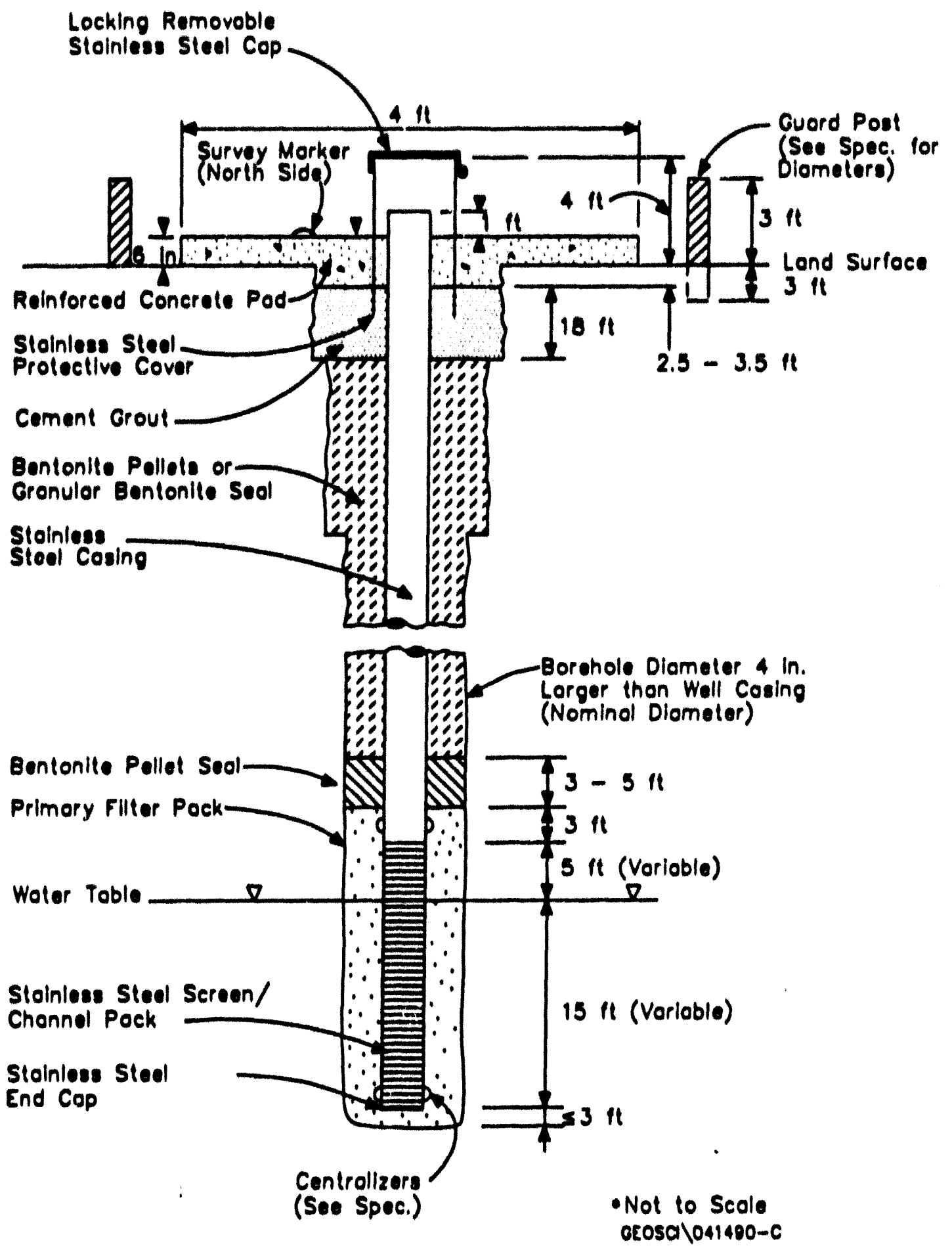


unconfined aquifer, but may not be suffictent for the full decrease in the water table that would result from termination of all activities in the 200 Areas.

Screen-slot sizes are preselected to avold delays that may be caused by determining correct slot sizes, ordering, and shipping. Sand filter packs will be placed in the annulus between the $20-\mathrm{cm}(8-1 \mathrm{n}$.) telescoping screen or the temporary $(20-\mathrm{cm}[8-1 \mathrm{n}]$.$) casing and the permanent (10-\mathrm{cm}[4-1 \mathrm{n}]$.$) casing$ and screen as the temporary casing is withdrawn. The sand filter pack will be placed from total well depth to 0.9 to $1.5 \mathrm{~m}$ (3 to $5 \mathrm{ft}$ ) above the top of the screen.

A $0.6-$ to $1.5-\mathrm{m}-(2-$ to $5-\mathrm{ft}-)$ thick bentonite pellet seal will be placed on top of the sand pack. The annulus between the bentonite pellet seal and $3.05 \mathrm{~m}(10 \mathrm{ft})$ below the ground surface will be filled with bentonite. Cement grout will then be installed to within $0.6 \mathrm{~m}(2 \mathrm{ft})$ of the ground surface. the well casing will extend 0.3 to $0.6 \mathrm{~m}(1$ to $2 \mathrm{ft}$ ) above the ground surface, and will be protected by an outer steel casing and a locking cap. The casing will be set into the ground and cemented in place within a 1.2- by 1.2-m (4by $4-\mathrm{ft}$ ) concrete well pad with bumper guards. All protective casings will be marked permanentiy with well identification numbers and a brass survey marker.

3.3.4.2 Well Development. All wells will be developed after completion following EII 10.3 (WHC-CM-7-7). Wells will be developed by the surge-andbat1 technique, overpumping, or any other techniques deemed necessary unt 11 turbidity is less than 5 nephelometric turbidity units (NTU) and sediment content is less than $8 \mathrm{mg} / \mathrm{L}$. If the water cannot be developed to turbidity of less than 5 NTU, an explanation will be documented by a qualified hydrogeologist. Other hydrochemical indicators, such as total iron and driling fluid tracers, may be monitored to assess the adequacy of development pumping for trace constituent sampling. Water will be pumped from the well only after the requirements for handling purge water have been met.

3.3.4.3 Surveying. After monitoring well installation is completed, all wells will be surveyed for location and elevation by qualified surveyors. The - levation of the top of the stainless steel protective casing and of a brass marker in the concrete pad will be determined within $0.003 \mathrm{~m}(0.01 \mathrm{ft})$. A mark will be placed on the casing to indicate the location that was surveyed. The areal location w111 be determined to the nearest $0.03 \mathrm{~m}$ $(0.1 \mathrm{ft})$. All measurements will be referenced to a common datum and reported in North American Datum 83 in meters. The survey results will be reviewed by a licensed surveyor.

\subsubsection{Monitoring Parameters}

Groundwater samples will be analyzed for the parameters listed in Table 5, as required by 40 CFR 265.92 . In addition, samples will be analyzed for tritium.

These const ftuents will be analyzed quarterly for 1 year from new wells and semiannually from existing wells. After 1 year of sampling, all wells will be analyzed on a semiannual basis. 
Table 5. Groundwater Sampling Parameters, Maximum Leve1. (2 sheets)

\begin{tabular}{|c|c|}
\hline Interim primary drinking water standards & Maximum level ${ }^{b}$ \\
\hline Arsenic & 0.05 \\
\hline Barium & 1.0 \\
\hline Cadmium & 0.01 \\
\hline Chromium & 0.04 \\
\hline Fluoride & 1.4 to 2.4 \\
\hline Lead & 0.05 \\
\hline Mercury & 0.002 \\
\hline Nitrate (as $\mathrm{NO}_{3}$ ) & 45 \\
\hline Selenium & 0.01 \\
\hline Silver & 0.05 \\
\hline Endrin & 0.0002 \\
\hline Lindane & 0.004 \\
\hline Methoxychlor & 0.1 \\
\hline Toxaphene & 0.005 \\
\hline $2,4-D$ & 0.1 \\
\hline 2,4,5-TP Silvex & 0.01 \\
\hline Radium & $5 \mathrm{pCi} / \mathrm{L}$ \\
\hline Gross alpha & $15 \mathrm{pCi} / \mathrm{L}$ \\
\hline Gross beta & $4 \mathrm{mrem} / \mathrm{yr}$ \\
\hline Turbidity (surface water only) & $1 \mathrm{TU}$ \\
\hline Coliform bacteria & $1 / 100 \mathrm{ml}$ \\
\hline \multicolumn{2}{|c|}{ Groundwater quality parameters } \\
\hline \multicolumn{2}{|c|}{$\begin{array}{c}\text { Chloride } \\
\text { Iron } \\
\text { Manganese } \\
\text { Phenols } \\
\text { Sodium } \\
\text { Sulfate }\end{array}$} \\
\hline \multicolumn{2}{|c|}{ Groundwater contamination indicator parameters } \\
\hline \multicolumn{2}{|c|}{$\begin{array}{l}\text { pH } \\
\text { Specific conductance } \\
\text { Total organic carbon } \\
\text { Total organic halogen }\end{array}$} \\
\hline
\end{tabular}

Regulatory requirements for sampling parameters are subject to change because of federal regulations.

Unless otherwise noted, concentrations are in $\mathrm{mg} / \mathrm{L}$.

$T U=$ Turbidity units. 


\subsection{HYDROGEOLOGIC CHARACTERIZATION}

Subsurface characterization will be conducted to describe the geologic and hydrogeologic conditions and properties that control contaminant flow paths. Data collection and interpretation will focus on geology, geochemistry, hydrogeology, hydrochemistry, groundwater contaminant monitoring, and groundwater modeling. The characterization effort will be performed during and after construction of the planned monitoring wells. An outline of the work to be performed is included below. Information obtained from the existing wells and planned wells will also be integrated into the characterization and interpretation effort. The characterization effort is an iterative discovery process, and data collection in these areas may expand or decrease, depending on the information obtained.

\subsubsection{Quality Assurance}

All work performed during and after well installation will follow the quality assurance data quality objectives detalled in the Quality Assurance Project Plan for RCRA Groundwater Monitoring Activities, WHC-SD-EN-QAPP-001, Rev. 1 (WHC 1992C), which meets the EPA requirements of QAMS-005/80 (EPA 1983).

\subsubsection{Geologic Characterization}

Geologic characterization will include geologic sampling, 1ithology description, a variety of physical and chemical laboratory analyses, and geophysical borehole logging (i.e., gross gamma log).

3.4.2.1 Geologic Sampling. Representative samples for geologic analysis will be collected at $1.5-\mathrm{m}$ (5-ft) intervals, at changes in 1ithology, and when significant changes in moisture content are observed. No driling water or other material will be added to the borehole during drilling unless necessary and approved by the well site geologist so that perched water zones can be detected, representative moisture samples can be taken, and water chemistry will not be affected. Samples for moisture content determinations will be collected at $1.5-\mathrm{m}(5-\mathrm{ft})$ intervals and at moist or wet zones. No moisture samples will be taken during hard tool drilling.

A description of the borehole cuttings between sampling intervals will be recorded to obtain a continuous lithologic record. Lithologic descriptions of samples will include color, texture, sorting, mineralogy, roundness, relative calcium carbonate concentration, consolidation, and cementation. The samples collected will be described as hand specimens in the field and documented on geologic $\log$ forms in accordance with WHC-CM-7-7, EII 9.1. Samples will be archived for possible future analyses. Drilling, well construction, and sample information will be documented on the borehole logs. Subsurface data collection and documentation during cable tool drilling is conducted in accordance with WHC-CM-7-7, EII 5.2, and the procedures for groundwater sampling are presented in WHC-CM-7-7, EII 5.8 and EII 6.7.

3.4.2.2 Laboratory Analyses. Calcium carbonate content and moisture content will be performed on geologic samples collected at $1.5-m(5-\mathrm{ft})$ intervals or on samples selected by the well site geologist. Moist or wet zones, where 
they can be sampled, will be analyzed for volatile hydrocarbons. Other laboratory analyses, including sieve analysis, moisture content, saturated hydraulic conductivity, petrographic description and/or $x$-ray diffraction analysis of mineral content, water retention, and hydrometer analyses of silt/clay zones will be performed on samples selected by the project scientist.

3.4.2.3 Borehole Geophysical Logging. Boreholes will be logged with a grossgamma probe after the placement of each temporary casing and when the borehole is drilled to final depth. Logging of the 6-m $(20-\mathrm{ft})$ starter casing will not be done unless requested by the weil site geologist. The primary purpose of this logging is to correlate and interpret subsurface stratigraphy. Also, logs may be used to identify zones of contamination by gamma ray-emitting radionuclides. If requested by the project scientist, each well may be viewed by a downhole video camera after completion, to verify that the well is clean and undamaged. Other logging probes, including the spectral gamma probe, may be used in specific instances when requested by the project scientist. All logging will be performed according to approved Westinghouse Hanford procedures.

\subsubsection{Hydrogeologic Characterization}

Data that will be used to characterize the hydrogeology will be collected during and after drilling of the monitoring wells. The general types and methods of data collection are discussed below. Groundwater samples will be taken following the procedures discussed in the sampling and analysis plan (Appendix C), or their revised, approved, and documented equivalents.

3.4.3.1 Aquifer Testing. The purpose of aquifer testing is to determine the hydraulic characteristics of in situ geologic materials in the uppermost aquifer underlying the site. A field testing program is essential to optimize collection of hydrologic data. However, the primary purpose of installing the wells is to monitor the groundwater chemistry and not for aquifer testing. Therefore, the results must be considered in this perspective.

Aquifer testing that involves pumping groundwater out of the well will be conducted only if adequate means exist for disposing of the purge water at the time the wells are ready for testing. A groundwater sample may be collected and analyzed before ajuifer testing begins. The results may be used to determine the handling and disposal of purge water. Slug testing will most likely be used, because of the purge water issue. Testing will be conducted in accordance with WHC-CM-7-7, EII 10.1, "Aquifer Testing."

A bailer will be used to remove drilling fluids and coarse materials from the borehole. Pretest well development by pumping will be conducted after bailing to determine the optimum discharge rate and, thus, the pump size for the constant discharge test. If the pump has a check valve, then pretest development will consist of pumping at a low flow rate followed by successively higher flow rate steps until full pump capacity or maximum drawdown has been achieved. If the pump is not equipped with a check valve, a surging technique will be used where the pump is alternately turned on and off followed by step pumping as described above. The constant discharge test will not be performed until water levels have recovered fully from the development test. 
A number of aquifer test methods may be used in the fleld testing program depending on the hydrologic parameter sought and existing hydraulic test conditions. Some test methods commonly used include baller, slug, development, constant discharge, and recovery techniques. Constant discharge tests could be conducted for up to 24 hours in those cases where at least one observation well is avallable and drawdown is large enough (greater than $0.06 \mathrm{~m}[0.2 \mathrm{ft}])$ to allow a quantitative analysis of the data. When avallabie, data from the observation wells can be analyzed to yield estimates of transmissivity, storativity and, sometimes, hydraulic conductivity anisotropy. Results from constant discharge tests can also be used to verify lateral continuity. Single-well constant discharge tests normally can be conducted for up to 8 hours. Tests of 8-hour duration can be used to estimate transmissivity.

A constant discharge pumping test should be conducted in one upgradient and one downgradient well. If a constant discharge pumping test is conducted, a temporary section of nominal 20-cm (8-in.) telescoping screen will be set in each of the wells before pumping. The screen will be open to the uppermost portion of the aquifer.

A submersible pump will be placed in the bottom portion of the screened interval. If the sediments in the test interval appear to have relatively high permeabilities, such as those characteristic of the Hanford formation, a large discharge rate will be required. The largest pump size that will fit in a nominal 20-cm (8-in.) telescoping screen (normally $40 \mathrm{hp}$ ) will be used in this case because it is expected that even a maximum discharge from this size pump (757 to $946 \mathrm{~L} / \mathrm{min}[200$ to $250 \mathrm{gal} / \mathrm{min}]$ ) will produce oniy a small drawdown (no more than $0.60 \mathrm{~m}[2 \mathrm{ft}]$ ).

If sediments in the test interval have low permeabilities, such as those characteristic of the Ringold Formation, a much lower discharge rate will be required and a smaller pump can be installed. In some locations, the sediments in a test interval may be of such low permeability that a pumping test would not be possible. In these situations, a siug test may be conducted.

A slug test may be conducted in the following manner. The drive casing will be pulled back a few feet to expose the formation to the open hole. If heaving or caving formations are expected, a temporary section of telescoping screen will be set in the well before testing. The screen may be set as described above for the constant discharge pumping test. The borehole will be bailed to remove drilling fluids and debris before conducting the test. During the slug test, the hydraulic head will be changed instantaneously by suddenty introducing or removing a cylinder of known volume. The water-level recovery response will then be observed over time.

A slug test will not yield representative results if the interval is of heterogeneous materials with hydraulic conductivities ranging over several orders of magnitude. In this case, split-spoon samples may be collected, and laboratory tests may be used to determine hydraulic conductivity.

One or two days of continuous water-level monitoring will be conducted (if scheduling permits) before and/or after terminating the pumping tests. These data will be used to determine whether outside influences, such as barometric effects, will have a significant impact on the tests. If so, the data will be corrected for these effects. 
The conventional analysis methods by Cooper and Jacob (1946) and Theis (1935) can be used to estimate transmissivity in the unconfined aquifer (Graham et al. 1981). Modifications of these methods can be used to correct for partial penetration effects, delayed yield response, leakage effects, and borehole storage effects. Slug test methods that can be used include Hvorslev (1951), Cooper et al. (1967), and Bouwer (1989). The laboratory methods to determine hydraulic conductivity include the falling-head or constant-head permeameter tests (Klute and Dirksen 1986).

3.4.3.2 Determination of Groundwater Flow Paths. Water levels will be measured in all wells of the SALDS groundwater monitoring network and in several nearby existing wells to determine the hydraulic head distribution used in determining groundwater flow paths. Measurements will al so be made over time to evaluate temporal changes in flow paths.

3.4.3.3 Data Interpretation and Presentation. The hydrogeologic data will be integrated with existing data (in WHC 1993) to develop an updated conceptual model of the groundwater flow system. Components of the model include definition of hydrostratigraphic units, evaluation of groundwater flow paths and velocities, evaluation of unsaturated zone conditions as they relate to the groundwater monitoring system, and hydrochemical characterization.

The data also will be used to evaluate whether the characterization effort was adequate or whether the groundwater monitoring system is designed appropriately. Recommendations may be provided for additional characterization activities or additional groundwater monitoring wells, if necessary.

The data and interpretations will be presented in a characterization report and in permitting documents. The report specifically will include descriptions of hydrostratigraphic units, water-level data and water table maps, test data and results of analyses, as-built diagrams of wells, hydrochemistry data, and recommenditions for further characterization or additional monitoring wells, if necessary.

\subsection{SAMPLING AND ANALYSIS}

The new wells will be sampled quarterly for 1 year and semiannually thereafter in accordance with 40 CFR 265.92. The depth to water will be measured before the wells are purged. The wells will be purged and samples will be collected after at least three borehole volumes have been removed, when specific conductance and $\mathrm{pH}$ have stabilized or, in the case of wells completed in very low permeability materials, after the well has recharged. Sampling, preservation, and chain-of-custody procedures are discussed in Appendix $C$. The quality assurance/control protocols, which are in addition to 40 CFR 265.92 requirements, are al so given in Appendix $C$. The purpose of quality control activities is to determine and document the quality of analytical results being produced by the laboratory and to institute corrective actions as necessary.

Under the indicator evaluation monitoring program, groundwater surface elevation data will be evaluated at least annually to determine if the existing monitoring wells are located appropriately. If the evaluation indicates that existing wells are no longer located adequately, the 
groundwater monitoring system will be modified to bring it into compliance with 40 CFR 265.91(a).

\subsection{STATISTICAL NMALYSIS OF GROUNDWATER MONITORING DATA}

The methods for establishing background and evaluating water chemistry data, and the reporting requirements are discussed below.

\subsubsection{Mothods}

Quarterly samples will be collected for 1 year from the new groundwater monitoring wells for chemical analyses for the constituents listed in Table 5, as required by 40 CFR 265.92. This 1 ist may have additions based on an evaluation of the initial results. The first set of samples from the new wells will be collected after the wells have been completed, developed, and have had sampling pumps installed. Depths-to-water will be measured before the wells are purged.

After 1 year of quarterly monitoring, background levels for indicator parameters will be redetermined and compared with indicator parameters from downgradient wells semiannually in accordance with 40 CFR 265.93. The data will be analyzed to evaluate whether groundwater is affected by the nonradioactive dangerous waste landfili.

\subsubsection{Establishing Background}

Background summary statistics (mean, variance, and coefficient of variation) will be calculated from five quarters of data from the existing well (Hall 1988, pp. 51-64) and will be calculated for new wells as data become avallable. The actual method that will be used for calculating summary statistics will depend on the distribution of the data and the presence of any data reported as less than the limit of detection. Replicate summary statistics will be calculated each quarter. Background comparison summary statistics will be calculated from the quarterly summary statistics.

Samples will be collected semiannually after the initial five-quarter sampling period, and analyzed semiannually from the background wells. The data will be evaluated to determine if trends are present, if irregularities exist in the data, or if groundwater from the wells is affected by the SALDS. If any of these conditions are present, or as new upgradient wells come on line, the data will be evaluated in relation to the hydrologic system to determine if the background levels need to be recalculated from a new set of quarterly sample data. The data will also be evaluated to determine whether the wells being used are suitable for that purpose or if additional wells are required.

\subsubsection{Evaluation of Data}

Wells will be sampled at least twice each succeeding year after background concentrations have been established. A minimum of four replicate measurements will be obtained from each downgradient well for the 
contamination indicator parameters, and the arithmetic mean and variance will be calculated for the contamination indicator parameters for each sample.

The averaged replicate $t$-test will be used to determine statistically significant changes in the concentration of contamination indicator parameters of downgradient wells as compared to inttial background concentrations or values. This comparison will consider each of the wells in the monitoring system individualiy. For three of the contamination indicator parameters, (specific conductance, total organic carbon, total organic halogen), a singletalled averaged replicate t-test will be used to test at the 0.01 level of significance for significant increases over background. The difference test for $\mathrm{pH}$ will be a two-talled averaged replicate t-test at the overall 0.01 level of significance.

\subsubsection{Notification and Reports}

A summary of reports required by 40 CFR 265, Subpart $F$ is given in Chapter 4.0. 
Rev. 0

This page intentionally left blank. 


\subsection{PHASE II--IMITIATION OF GROUNOWATER QUALITY ASSESSHENT PROCRAM}

This chapter discusses the development of criteria that would trigger notiffcation of regulatory agencles and inltiate a groundwater quality assessment program. The notffications required by 20 CFR 265, subpart F are presented, and the groundwater quallty assessment program is outlined. Because this is a designated tritfum disposal site, tritfum will be excluded from consideration because it is expected to be detected in the downgradient wells.

\subsection{INITIATION CRITERIA}

As indicated in Chapter 3.0, groundwater samples from all monitoring wells will be tested quarterly for interim primary drinking water constituents, groundwater quality parameters, groundwater contamination indicator parameters, and site-spectfic parameters for the first year (see Table 5).

Significant changes in concentrations from both upgradient (background) and downgradient wells must be reported. If significant changes are noted in the downgradient wells, those wells must be resampled immediately, and the samples spilt in two and analyzed by independent laboratories to determine if the results were caused by laboratory error. If this second sampling also shows a signiftcant Increase (or PH decrease), the EPA and Ecology must be notifled in writing within 7 days that the SALDS may be affecting groundwater quality. If a significant increase (or pH decrease) is confirmed by the second sampling, a plan for a groundwater qual lty assessment program must be submitted to EPA and Ecology within 15 days of this written notification. The outline of the groundwater quality assessment program is presented in the following section, as required by 40 CFR 265.93 (a).

\subsection{GROUNDWATER QUALITY ASSESSMENT PROGRAY}

A groundwater quality assessment program will be implemented when a release of hazardous constituents is indicated in the indicator evaluation monitoring system. The decision to implement the groundwater quality assessment program will be based on criterla described in the previous section. A groundwater quality assessment plan will be certified by a qualified hydrogeologist. This plan will address the following:

- Groundwater monitoring wells that will be drilled, as necessary, to determine the nature and extent of contamination. The number, location, and depth of each well will be identified

- Groundwater samples that will be collected and analyzed at a minimum for constituents outilined in Appendix IX of 40 CFR 264 
- Detalled procedures describing how the analytical results will be evaluated, including the analysis of any prevfously gathered groundwater quality information

- A schedule for implementation of the assessment-level groundwater monitoring program.

A sample outline of a groundwater quality assessment plan follows.

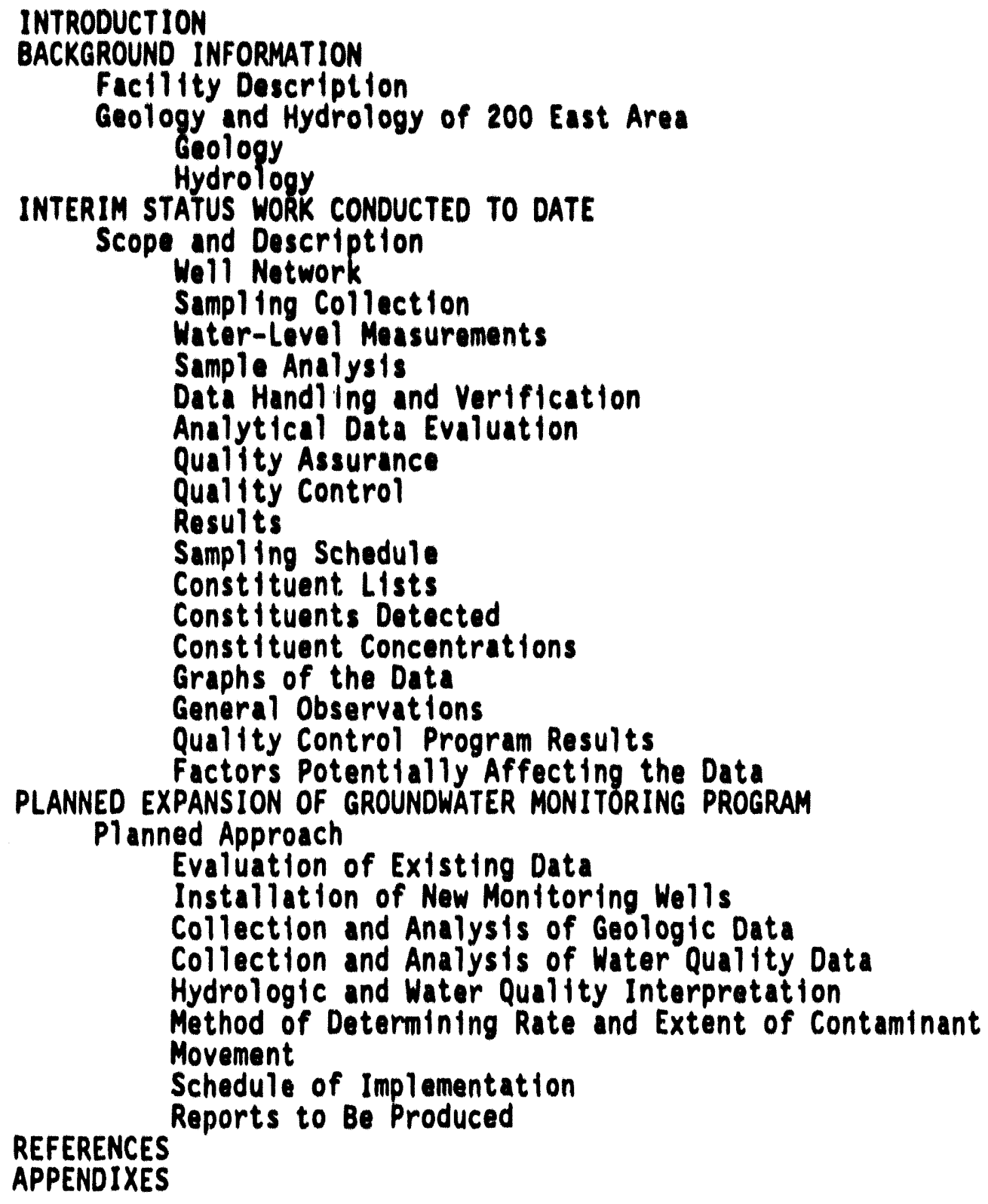

Additional explanations for several items that will be addressed in the plan are provided below.

At sites where contaminants are known to have entered the groundwater, the regulations specified in 40 CFR 265.93 (d)(4) require that the rate and extent of contaminant movement be determined. The methods used to determine these will depend on the quantity and quality of the fleld database. Methods 
will include installation of additional monitoring wells and field testing, continued chemical analyses of selected constituents in existing and new well installations, groundwater flow and contaminant transport modeling, and statistical evaluation of chemical analyses.

\subsubsection{Mature and Extent of Contanination}

Analytical data from now and existing wolls will be evaluated to determine the specific hazardous and nonhazardous constituents and levels of these constituents found in groundwater. In addition, the hazardous constituents w1ll be evaluated statistically to determine which exceed background concentrations. The data will be further evaluated to determine if particular constituents have come from the nonradloact ive dangerous waste landfill or may originate from some other waste management facility.

The lateral extent of contamination wlll be estimated by contouring concentrations of varlous hazardous and nonhazardous const ituents. The concentrations of hazardous constituents w111 be contoured to estimate the actual contamination distributions; the concentrations of nonhazardous constituents will be contoured and evaluated as indicators of groundwater and contaminant movement. The rate and extent of contamination wifl be evaluated conceptually based on existing data and modeling results (see section 4.2.5).

\subsubsection{Rate of Movement}

The rate of contaminant movement will be estimated initially by using values of hydraulic conductivity estimated from aquifer testing, the hydraulic gradient determined from water-level measurements, and an est imated effect fve porosity based on the nature of the geologic material. This will provide gross estimate for application in modeling studies and additional monitoring programs. The rate and extent of contamination will be ovaluated conceptually based on extsting data and modeling resuits (see section 4.2.5). The result: of the evaluation will provide insight into the areas of greatest uncertainty and thus those areas where additional data are needed. Additional wells and field testing will most likely be necessary to quantify the rate and extent of contamination.

\subsubsection{Additional Woll Installation}

Examination of the analytical results obtained under the indicatorevaluation program, coupled with prei iminary flow and transport modeling (see Section 4.2.5) will provide the bases for locating additional monitoring wells. Data from these wells will be used to further define and quantify the rate and extent of contamination.

\subsubsection{Additional Field and Laboratory Testing}

Samples will be collected from new and existing wells and analyzed for known hazardous waste or hazardous waste const 1tuents and other constituents that will be useful for evaluating rate and extent of contamination. Additional fleld testing (e.g., pumping and tracer tests) and laboratory 
testing may also be necessary. The primary focus of additional field or laboratory testing w11l be those parameters with the highest uncertainty and that most affect flow and transport. These factors will be evaluated by preliminary modeling and sensitivity analyses. Additlonal fleld and/or Taboratory testing may be conducted to determine the following:

- Quantitative and representative values and distribution of hydraulic conductivity

- Quantitative values of porosity

- More accurate spatial and temporal distributions of hydraulic head

- Retardation characteristics

- Quantitative values of dispersivity.

\subsubsection{Modoling}

Simple analytical models that include terms for dispersion, retardation, and radioactlve decay will be used to simulate the extent and rate of contaminant plume movement based on assumed hydraulic and ratardation parameters. Numerical models that can accommodate heterogenelties in the hydrogeologic system and more complex transport condittons can also be used to estimate the rate and direction of flow under various hydrologic conditions. As previously mentioned, the results of modeling will be used to locate additional wells and to identify data needs.

\subsection{CONTINUED AMALSIS NO EVALUATION}

This section discusses the review and evaluation that will be conducted on initiation of the groundwater quality assessment program. The required notifications and reports are iso discussed.

\subsubsection{Rovlaw of Mothods and Procedures}

On verification of contamination in groundwater monitoring wells, the monitoring system, data evaluation mothods, and sampling and analysis procedures will be revlewed. This revtew will evaluate the adequacy of the groundwater monitoring system to determine if contamination may be originating from a source other than the SALDS. The method of estabilishing background will be revlowed for lts approprlateness within the hydrogeologic system. This reviow will consider the potentlal effects of other facilities that may result in trends in background water quality that have not been addressed in establishing background. Finally, the revlew will evaluate the current sampling and analysis procedures, and whether sample blas may result from inadequactes in the procedures. 


\subsubsection{Roviow of Sampling Parameters and Frequency}

The sampling plan w11l be reviewed to evaluate if the approprlate parameters are being analyzed and if the frequency is adequate. The groundwater quality assessment program will require the addition of any hazardous constituents that have been detected. The sampling frequency will be returned to quarterly from semiannually until it is dotermined that no hazardous waste or hazardous waste constituents from the SALDS have entered the groundwater, or unt 11 final closure of the factilty, as required by 40 CFR 265, Subpurt F.

\subsubsection{Notiffeation and Reports}

Table 6 ilsts the reports and notffications that must be submitted (1) whether or not the facllity might be affecting groundwater or (2) if the facllity may be affecting groundwater as determined by the method mentioned above (student's t-test).

Records of the groundwater qualtty analyses, assoclated groundwater surface elevations, and the varlous data analyses (including the statistical analyses) will be kept throughout the active iffe of the SALDS and throughout the postciosure pertod as well (40 CFR 265.94[a][1]). 
Table 6. Reports and Notifications.

\begin{tabular}{|c|c|}
\hline Submittal & Submittal period \\
\hline \multicolumn{2}{|c|}{ Required whether or not the facillty may be affecting groundwater } \\
\hline $\begin{array}{l}\text { First year of sampling only; } \\
\text { concentrations of interim primary } \\
\text { drinking water, standards, ident ifying } \\
\text { those that exceed the limits listed in } \\
\text { Tabie } 5\end{array}$ & $\begin{array}{l}\text { Within } 15 \text { days of each quarterly } \\
\text { analys is }\end{array}$ \\
\hline $\begin{array}{l}\text { Concentration and statistical analyses } \\
\text { of groundwater contamination indicator } \\
\text { parameters, noting significant } \\
\text { differences in upgradient welis }\end{array}$ & Annually, by March 1 of following year \\
\hline $\begin{array}{l}\text { Results of groundwater surface } \\
\text { elevat ion evaluation and description } \\
\text { of response if approprtate }\end{array}$ & Annually, by March 1 of following year \\
\hline \multicolumn{2}{|c|}{ Required if the facility may be affecting groundwater } \\
\hline $\begin{array}{l}\text { Notification to EPA and Ecology that } \\
\text { the facility may be affecting } \\
\text { groundwater }\end{array}$ & $\begin{array}{l}\text { Within } 7 \text { days of confirmation of a } \\
\text { significant increase (or pH decrease) }\end{array}$ \\
\hline $\begin{array}{l}\text { Submittal of groundwater assessment } \\
\text { plan to EPA and Ecology }\end{array}$ & $\begin{array}{l}\text { Within } 15 \text { days of the above } \\
\text { not ification }\end{array}$ \\
\hline $\begin{array}{l}\text { Submittal to EPA and Ecology of a } \\
\text { written report on assessment of } \\
\text { groundwater quality, including } \\
\text { concentrations of hazardous waste } \\
\text { constituents and their rate and extent } \\
\text { of migration }\end{array}$ & $\begin{array}{l}\text { Within } 15 \text { days of first determination } \\
\text { (as soon as technically feasible) }\end{array}$ \\
\hline $\begin{array}{l}\text { Results of the groundwater quality } \\
\text { assessment program }\end{array}$ & $\begin{array}{l}\text { Annually, by March l of following } \\
\text { year, untif ciasure of the facility }\end{array}$ \\
\hline
\end{tabular}

Ecology = Washington Department of Ecology. EPA - U.S. Environmental Protection Agency. 


\subsection{REFERENCES}

Bouwer, H., 1989, The Bouwer and Rice Slug Test - An Update, Ground Water, Vol. 27, No. 3, p. 304-309.

Cooper, H. H., Jr., and C. E. Jacob, 1946, "A Generalized Graphical Method for Evaluating Formation Constants and Summarizing Well Field History," Transactions of the American Geophysical Union, Vo1. 27, pp. 526-534.

Cooper, H. H., Jr., J. D. Bredehoeft, and I. S. Papadopulos, 1967, "Response of a Finite Diameter Well to an Instantaneous Charge of Water," Water Resources Research, Vol. 3, No. 1, pp. 263-269.

Delaney, C. D., K. A. Lindsey, and S. P. Reidel, 1991, Geology and Hydrology of the Hanford Site: A Standardized Text for Use in Westinghouse Hanford Company Documents and Reports, WHC-SD-ER-TI-003, Westinghouse Hanford Company, Richland, Washington.

DOE, 1988a, Consultation Draft, Site Characterization Plan, Reference Repository Location, Hanford Site, Washington, DOE/RW-0164, Vols. 1-9, Office of Civilian Radioactive Waste Management, U.S. Department of Energy, Washington, D.C.

DOE, 1988b, General Environmental Protection Program, DOE Order 5400.1, U.S. Department of Energy, Washington, D.C.

DOE-RL, 1989, Hanford Site Groundwater Protection Management Program, DOE/RL 89-12, U.S. Department of Energy, Richland Operations Office, Richland, Washington.

Driscoll, F., 1989, Groundwater and Wells, 2nd edition, Johnson Filtration Systems Inc., St. Paul, Minnesota.

Ecology, EPA, and DOE, 1989, Hanford Federal Facility Agreement and Consent Order, 2 vols, as amended, Washington Department of Ecology,

U.S. Environmental Protection Agency, and U.S. Department of Energy, 01 ympia, Washington.

EPA, 1976, National In arim Primary Drinking Water Regulations, EPA-570/9-76/003, U.S. Environmental Protection Agency, Office of Water Supply, Washington, D.C.

EPA, 1983, Interim Guidelines and Specifications for Preparing Quality Assurance Project P7ans, QAMS-005/80, EPA-600/4-83-004, U.S. Environmental Protection Agency, Washington, D.C.

EPA, 1986, RCRA Groundwater Monitoring Technical Enforcement Guidance Document, OSWER-9950.1, U.S. Environmental Protection Agency, Washington, D.C.

EPA, 1992, Docket Report on Health-Based Levels and Solubilities Used in the Evaluation of Delisting Petitions, Submitted Under 40 CFR 260.20 and 260.22, Delisting Section Waste Identification Branch, Office of Solid Waste, U.S. Environmental Protection Agency, Washington, D.C. 
Gee, G. W., 1987, Recharge at the Hanford Site: Status Report, PNL-6403, Pacific Northwest Laboratory, Richland, Washington.

Gephart, R. E., R. C. Arnett, R. G. Baca, L. S. Leonhart, and F. A. Spane, Jr., 1979, Hydrologic Studies Within the Columbia Plateau, Washington: An Integration of Current Knowledge, RHO-BWI-ST-5, Rockwel1 Hanford Operations, Richland, Washington.

Golder Associates Inc., 1992, Monitoring Analysis Package (MAP), User's Manual - Version 1.1, Golder Associates Inc., Redmond, Wa.shington.

Graham, M. J., M. D. Hall, S. R. Strait, and W. R. Brown, 1981, Hydrology of the Separations Area, RHO-ST-42, Rockwell Hanford Operations, Richland, Washington.

Graham, M. J., G. V. Last, and K. R. Fecht, 1984, An Assessment of Aquifer Intercommunication Within B Pond-Gable Mountain Pond Area of the Hanford Site, RHO-RE-ST-12 P, Rockwell Hanford Operations, Richland, Washington.

Hal1, S. H., 1988, Groundwater Monitoring Compliance Projects for Hanford Site Facilities: Annual Progress Report for 1987, PNL-6678, Pacific Northwest Laboratory, Richland, Washington.

Harris, S. F., and C. D. Delaney, 1991, Groundwater Quality Characterization at Three Candidate Sites for the C-O18H Soil Column Disposal Facility, WHC-SD-EN-013, Rev. 0., Westinghouse Hanford Company, Richland, Washington.

Hvorslev, M. J., 1951, "Time Lag and Soil Permeability in Groundwater Observations," U.S. Army Corps of Engineers Waterways Experiment il Station Bulletin, 36, Vicksburg, Mississippi.

Klute, A., and C. Dirksen, 1986, "Water Retention: Laboratory Methods," Methods of Soil Analysis, Part 1, ed. A. Klute, American Society of Agronomy, Madison, Wisconsin, pp. 687-732.

Koegler, K. J., 1990, Preliminary Site Evaluation Report for a Soil Column Disposal Site for the 242-A Evaporator and PUREX Plant Condensate Treatment Facility, WHC-SD-EN-002, Westinghouse Hanford Company, Richland, Washington.

Law, A. G., J. A. Serkowski, and A. L. Schatz, 1987, Results of the Separations Area Groundwater Monitoring Network for 1986, RHO-RE-SR-87-24P, Rockwell Hanford Operations, Richland, Washington.

Lindsey, K. A., and D. R. Gaylord, 1991, Sedimentology and Stratigraphy of the Miocene-Pliocene Ringold Formation, Hanford Site, South-Central Washington, WHC-SA-0740-FP, Westinghouse Hanford Company, Richland, Washington.

Resource Conservation and Recovery Act of 1976, 42 USC 6901 et seq.

Theis, C. V., 1935, "The Relation Between the Lowering of the Piezometric Surface and the Rate Duration of Discharge of a Well Using Ground-Water Storage," American Geophysical Union Transcript, Vo1. 16, pp. 519-524. 
WHC, 1992a, Groundwater Mounding and Plume Migration Analyses for Candidate Soil Column Disposal Sites, Hanford Site, Washington, WHC-SD-EN-ES-022, Westinghouse Hanford Company, Richland, Washington.

WHC, 1992b, Project C-018H Waste Water Engineering Alternatives Report, WHC-SD-CO18H-ER-001, Westinghouse Hanford Company, Richland, Washington.

WHC, 1992c, Quality Assurance Project Plan for RCRA Groundwater Monitoring Activities, WHC-SD-EN-QAPP-001, Rev. 1, Westinghouse Hanford Company, Richland, Washington.

WHC, 1993, Characterization Report, C-O18H Disposal siting Evaluation, WHC-SD-C-018H-RPT-001, Westinghouse Hanford Company, Richland, Washington.

WHC-CM-7-7, Environmental Investigations and site Characterization Manual, West inghouse Hanford Company, Richland, Washington.

40 CFR 141, 1992, "Nattonal Primary Drinking Water Regulations," Code of Federal Regulations, as amended.

40 CFR 143, 1992, "National Secondary Drinking Water Regulations:" Code of Federal Regulations, as amended.

40 CFR 264, 1992, "Standards for Owners and Operators of Hazardous Waste Treatment, Storage, and Disposal Facilities," Code of Federal Regulations, as amended.

40 CFR 265, 1992, "Interim Status Standards for Owners and Operators of Hazardous Waste Treatment, Storage, and Disposal Facilities, " Code of Federal Regulations, as amended.

50 FR 46936, 1985, "National Primary Drinking Water Regulations; Synthetic Organic Chemicals, Inorganic Chemicals and Microorganisms. Proposed Rulemaking, "Federal Register, November 13.

WAC 173-160, 1990, "Minimum Standards for Construction and Maintenance of Water Wells," Washington Administrative Code, as amended.

WAC 173-200, 1990, "Water Quality Standards of the State of Washington," Washington Administrative Code, as amended.

WAC 173-216, 1990, "State Waste Discharge Permit Program, "Washington Administrative Code, as amended.

WAC 173-303, 1990, "Dangerous Waste Regulations," Washington Administrative Code, as amended.

WAC 248-54, 1990, "Public Water Supplies," Washington Administrative Code, as amended. 
This page intentionally left blank. 
This page intentionally left blank. 


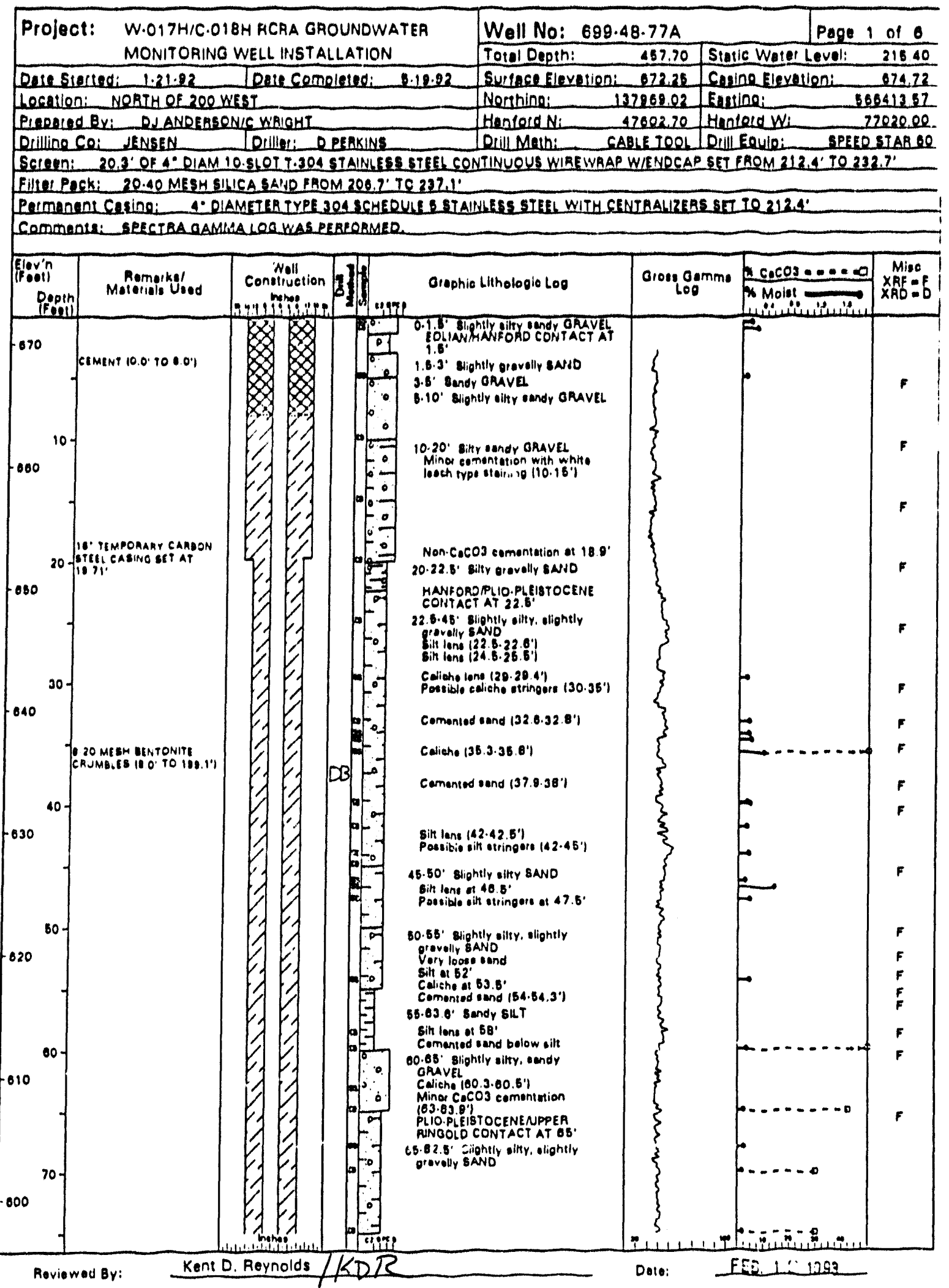




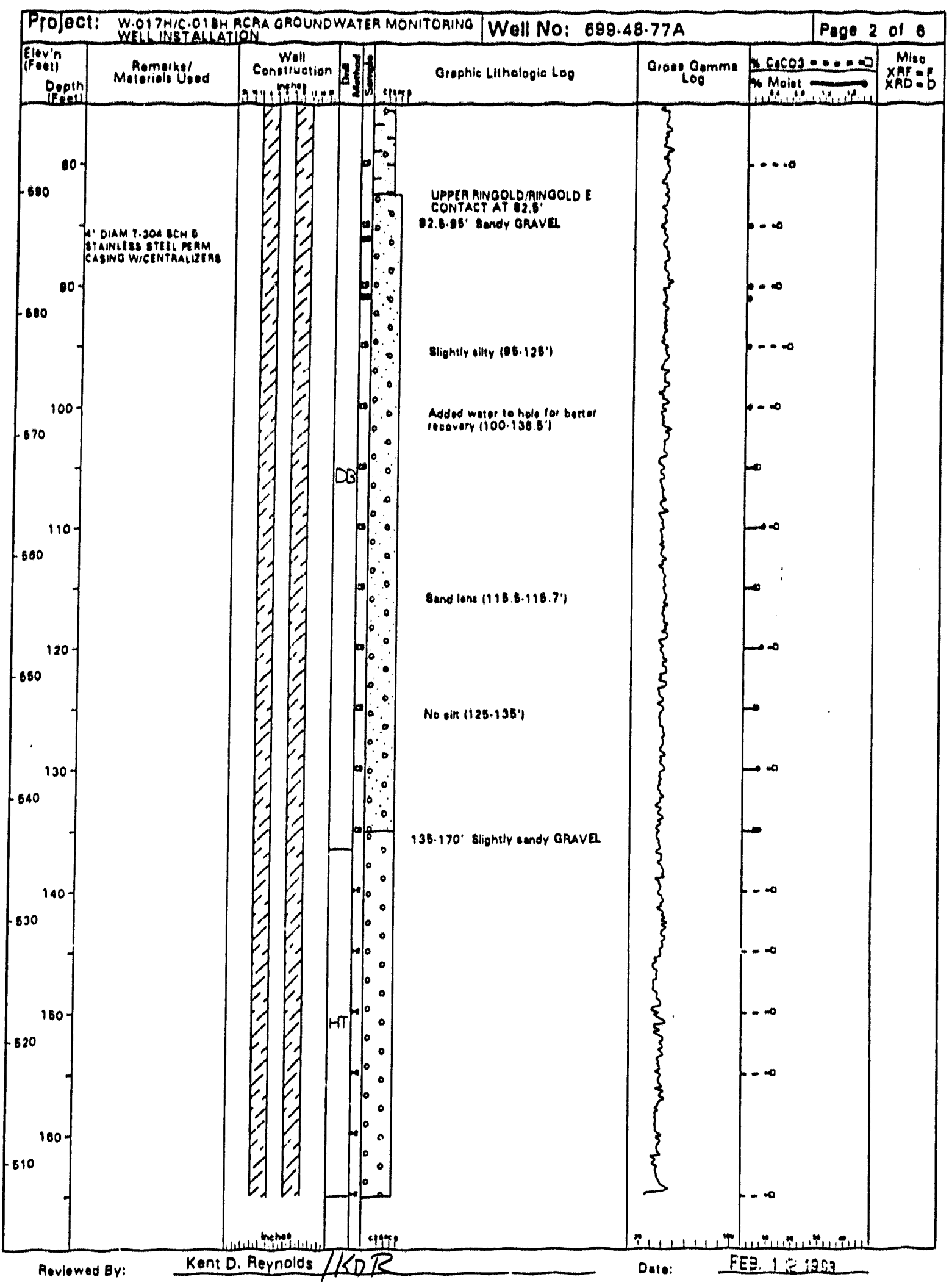




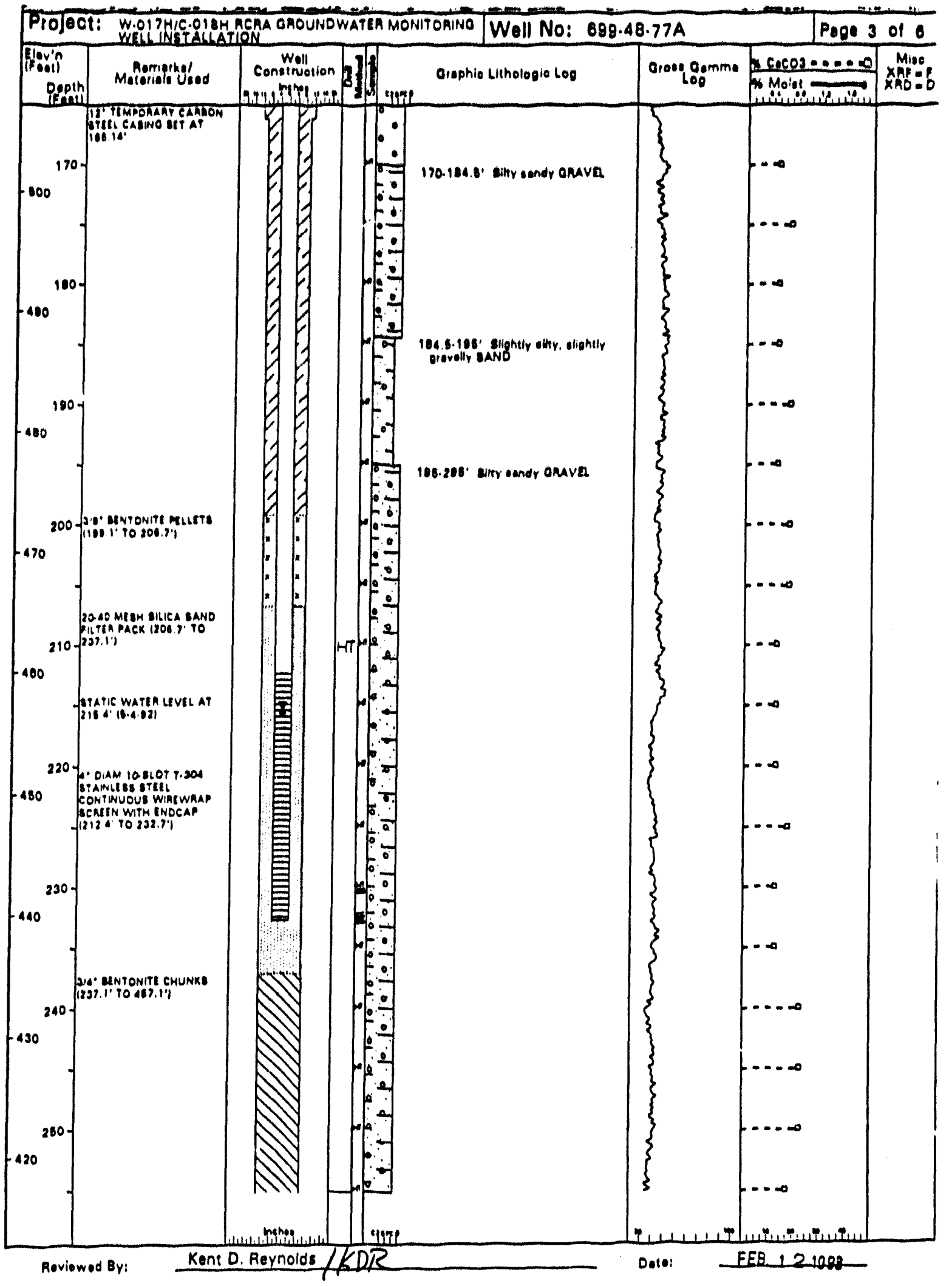




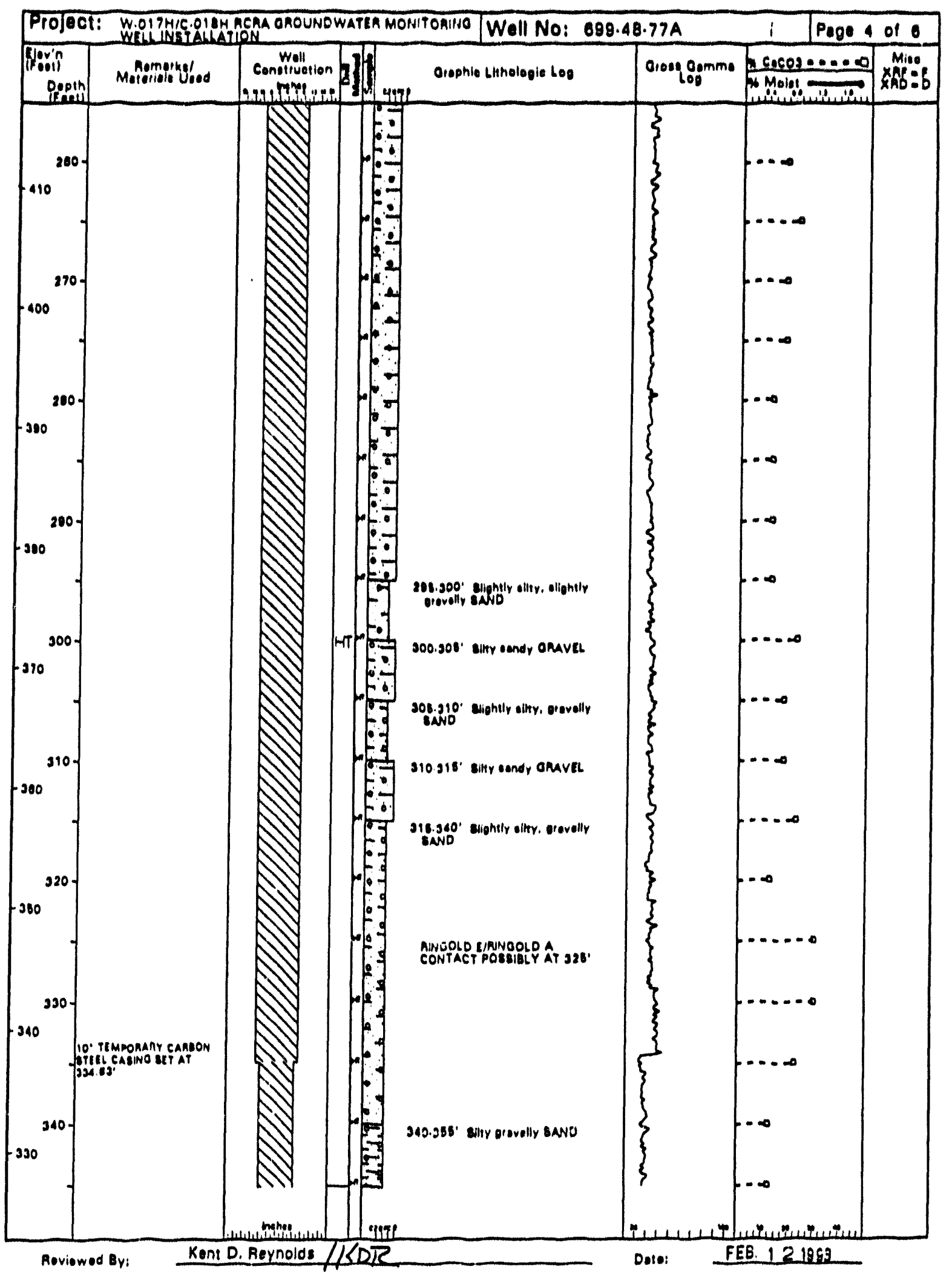




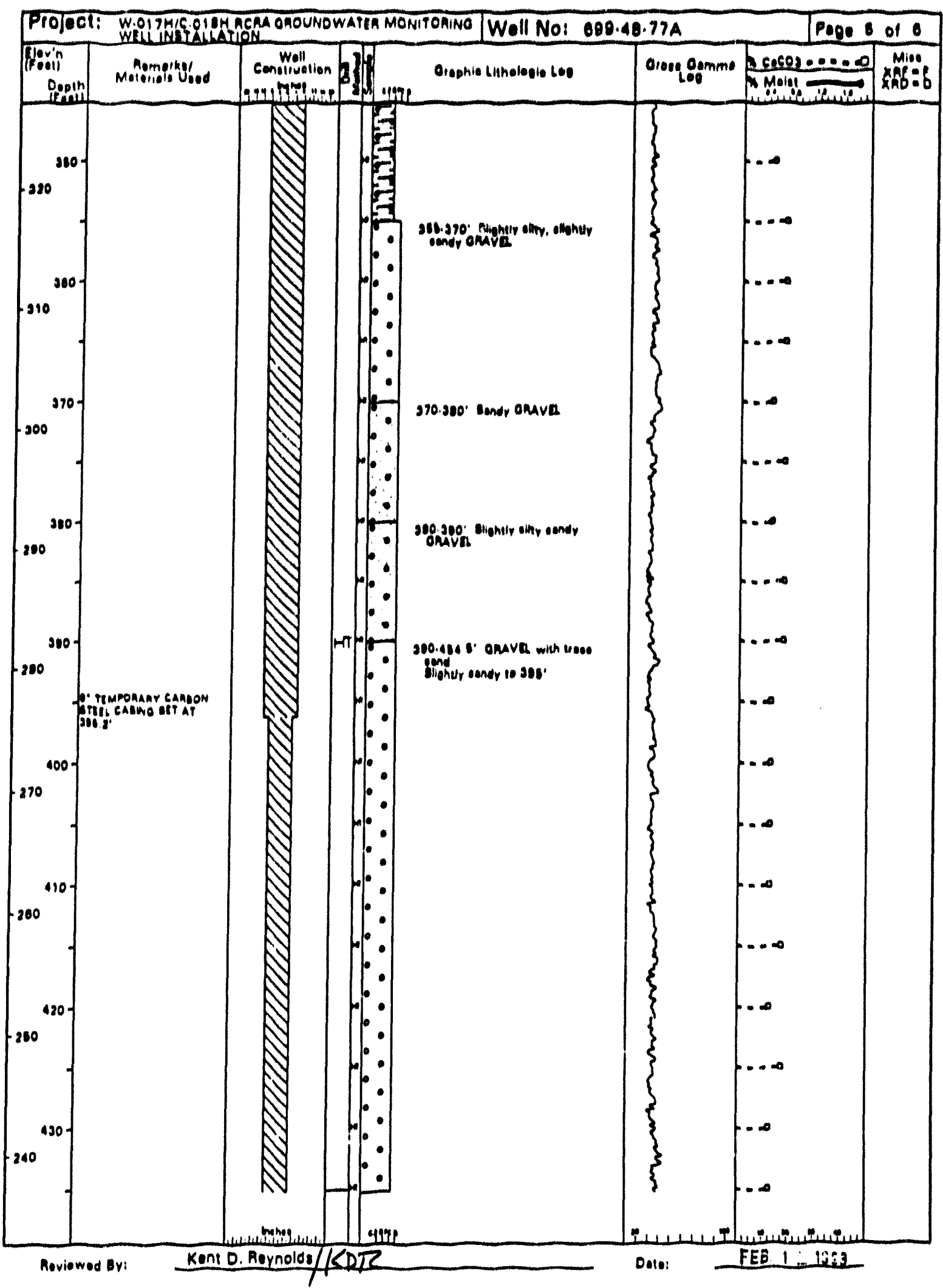




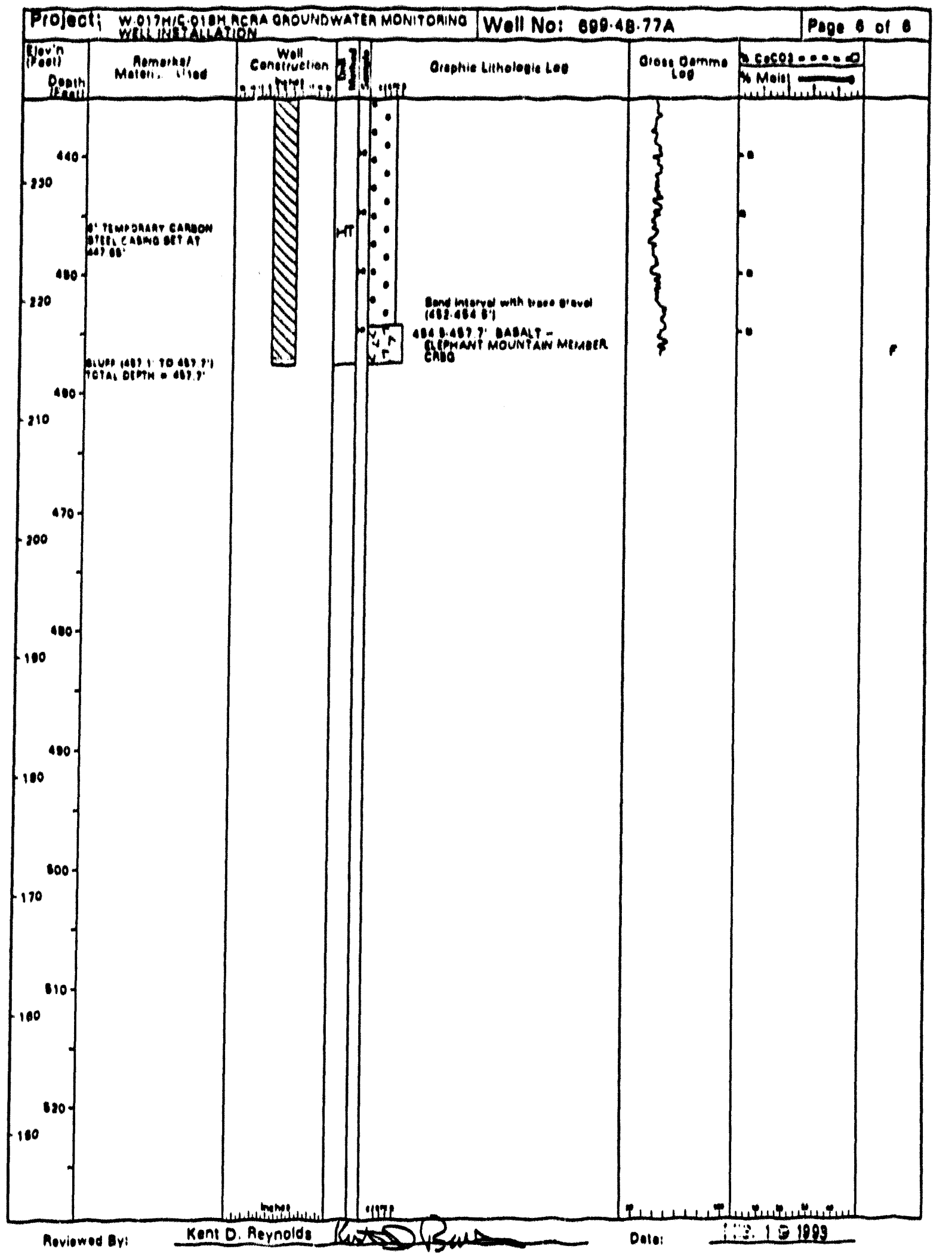




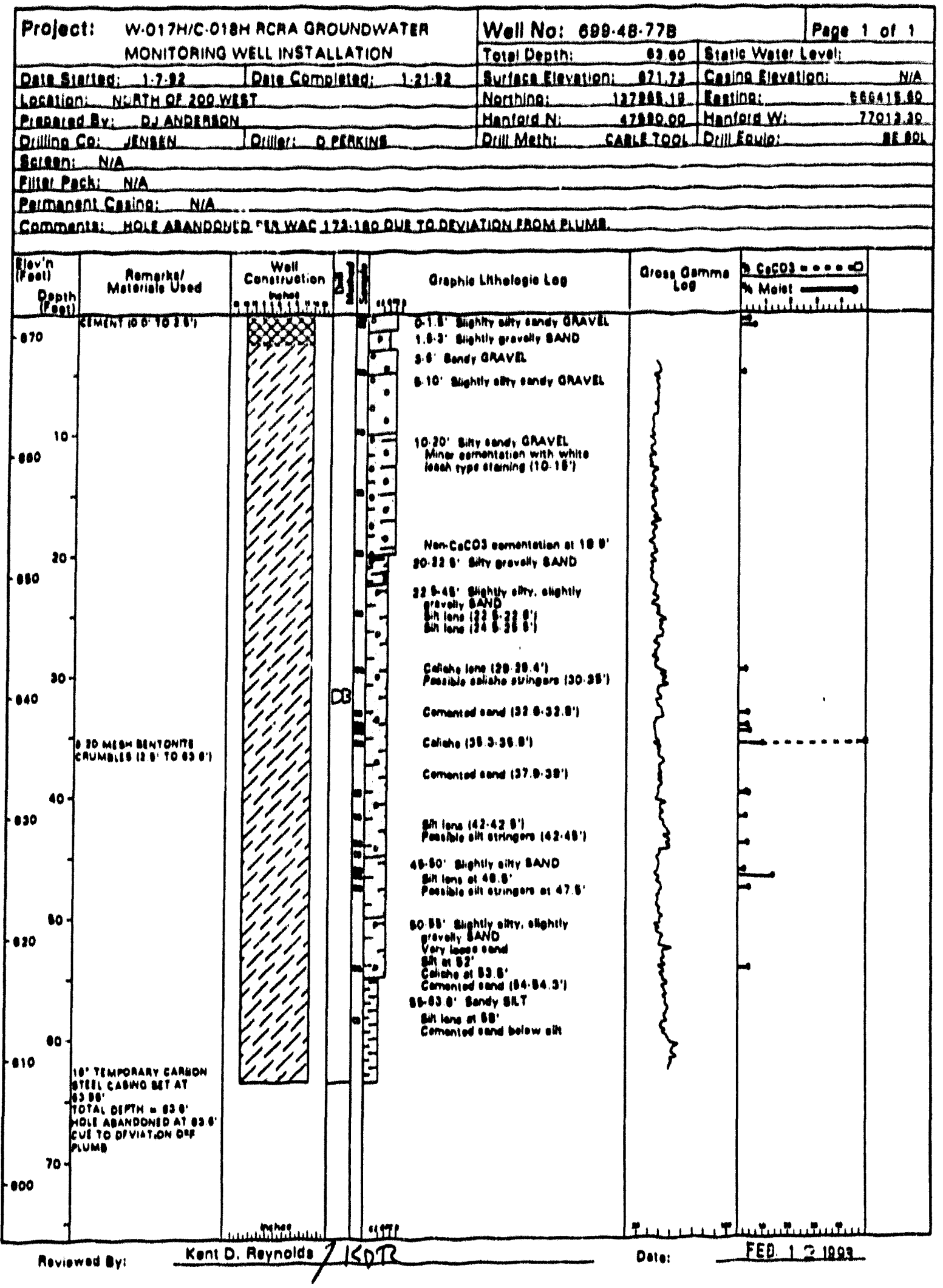


Rev. 0

This page intentionally left blank.

A-8 


\section{APPENDIX B}

SAMPLING AND ANALYSIS PLAN

$$
\text { B- } \mathbf{i}
$$


This page intentionally left blank. 
This appendix introduces the procedures that will be used for sample collection (including well evacuation and sample withdrawal methods); chain of custody; analytical methods, including sampling preservation and shipment and chemical analysis; and quality assurance/quality control.

All groundwater sampling activities are performed under contract by the Pacific Northwest Laboratory (PNL). Sample analyses will be carried out by a contract laboratory to be determined.

\section{B.1.1 SAMPLE COLLECTION PROCEDURES}

The procedures for groundwater sample collection, water-level measurement, and field measurements are contained in Procedures for Groundwater Investigations (PNL 1989a). Specific applicable procedures include the following:

- GC-1, "Groundwater Sample Collection Procedure"

- GC-2, "In-line Sample Filtration Procedure"

- GC-3, "Disposal of Purge Water from Monitoring Wells"

- FA-1, "Temperature Measurement Procedure"

- FA-2, "Calibration of Conductivity Meter and Measurement of Field Conductivity"

- FA-3, "Calibration of PH Meter and Measurement of Field pH"

-WL-1, "Water-Level Measurement Procedure"

- WL-2, "Procedure for Standardizing Stee1 Tapes"

- AD-1, "Change Control Procedure"

- AD-2, "Groundwater Sample Chain of Custody."

\section{B.1.2 CHAIN-OF-CUSTODY PROCEDURES}

Chain-of-custody procedures are contained in Procedures for Groundwater Investigations (PNL 1989a). The specific applicable procedure is AD-2, "Groundwater Sample Chain-of-Custody Procedure." The history of the custody of each sample will be documented according to this procedure. 


\section{B.1.3 ANALYTICAL METHODS}

Tables B-1 through B-8 indicate the methods used to analyze samples.

Table B-1. Metals by Inductively Coupled Plasma Spectrometry Using Method 6010 of SW-846 (EPA 1986).

\begin{tabular}{|c|c|}
\hline Constituent & CRQL (ppb) \\
\hline Antimony & 200 \\
\hline Barium & 20 \\
\hline Beryllium & 3 \\
\hline Cadmium & 10 \\
\hline Calcium & 100 \\
\hline Chromium & 20 \\
\hline Cobalt & 20 \\
\hline Copper & 20 \\
\hline Iron & 20 \\
\hline Magnesium & 100 \\
\hline Manganese & 10 \\
\hline Nickel & 30 \\
\hline Potassium & 300 \\
\hline Silver & 20 \\
\hline Sodium & 300 \\
\hline Tin & 100 \\
\hline Vanadium & 30 \\
\hline Zinc & 10 \\
\hline
\end{tabular}

"Contract required quantitation limit. 
Table B-2. Metals by Atomic Absorption.

\begin{tabular}{|c|c|c|}
\hline Constituent & CRQL (ppb) & Method $^{\mathrm{B}}$ \\
\hline Arsenic & 5 & 7060 (SW-846) \\
\hline Lead & 5 & 7421 (SW-846) \\
\hline Mercury & 0.2 & $7470(\mathrm{SW}-846)$ \\
\hline Selenium & 10 & $7740(\mathrm{SW}-846)$ \\
\hline Thallium & 5 & 7841 (SW-846) \\
\hline
\end{tabular}

'EPA (1986).

Table B-3. Antons by Ion Chromatography Using Either Method 300.0; EPA-600/4-84-017, March 1984;

or ASTM Method D4327-84 (ASTM 1985).

\begin{tabular}{|c|c|}
\hline Constituent & CRQL (ppb) \\
\hline \multicolumn{2}{|c|}{ Method 300.0} \\
\hline Chloride" & 2000 \\
\hline Nitrate & 2000 \\
\hline Nitrate & 2000 \\
\hline Phosphate" & 4000 \\
\hline \multicolumn{2}{|c|}{ EPA-600/4-84-017 } \\
\hline Chloride & 200 \\
\hline Nitrate ${ }^{c}$ & 200 \\
\hline Nitrate ${ }^{c}$ & 200 \\
\hline Phosphate $^{c}$ & 400 \\
\hline \multicolumn{2}{|c|}{ ASTM Method D4327-84 } \\
\hline Bromide $^{d}$ & 500 \\
\hline Chloride & 200 \\
\hline Fluoride ${ }^{d}$ & 100 \\
\hline Phosphate $^{d}$ & 400 \\
\hline Sulfated & 500 \\
\hline
\end{tabular}

"Preserved sample, diluted ten fold; chloride may be analyzed from a preserved sample

EPA (1984)

'Preserved sample, undiluted

Unpreserved, undiluted sample. 
Table B-4. Miscellaneous Parameters and Bacteriological Tests.

\begin{tabular}{|c|c|c|}
\hline Constituent & CRQL & Method \\
\hline Turbidity & $0.1^{\circ}$ & APHA $\# 214 A^{b}$ \\
\hline Coliform (fermentation) & $2.2^{c}$ & $9131(\mathrm{SW}-846)^{d}$ \\
\hline Collform (filter) & $1^{\bullet}$ & $9132(\mathrm{SW}-846)^{d}$ \\
\hline
\end{tabular}

Nephelometric turbidity units

APHA (1985)

"Most probable number

DEPA (1986)

Minimum colony count.

Table B-5. Volatile Organics to be Analyzed for by Method 8010/8020 of SW-846 (EPA 1986).

\begin{tabular}{|c|c|}
\hline Constituent & CRQL (ppb) \\
\hline Benzene & 2 \\
\hline Carbon tetrachloride & 1 \\
\hline Chloroform & 0.5 \\
\hline p-Dichlorobenzene & 2 \\
\hline $1,1-$ Dichloroethane & 1 \\
\hline 1,2 -Dichloroethane & 0.5 \\
\hline cis-1,2-Dichloroethylene & 1 \\
\hline trans-1,2-Dichloroethylene & 1 \\
\hline Ethylbenzene & 2 \\
\hline Methylene chloride & 5 \\
\hline Tetrachloroethylene & 0.5 \\
\hline Toluene & 2 \\
\hline $1,1,1-$ Trichloroethane & 0.5 \\
\hline $1,1,2-$ Trichloroethane & 0.2 \\
\hline Trichloroethylene & 1 \\
\hline Vinyl chloride & 2 \\
\hline Xylene (tota:) & 5 \\
\hline 1-Butanol & 1000 \\
\hline
\end{tabular}


Table B-6. Phenols by Gas Chromatography Using Method 8040 of SW-846 (EPA 1986).

\begin{tabular}{|c|c|}
\hline Constituent & CRQL (ppb) \\
\hline Phenol & 20 \\
\hline
\end{tabular}

Table B-7. Radiological Parameters.

\begin{tabular}{|c|c|c|}
\hline Constituent & CRQL $(P C i / L)$ & Method \\
\hline Radium & 1 & $9315(\mathrm{SW}-846)^{\circ}$ \\
\hline Gross alpha & 4 & 9310 (SW-846) \\
\hline Gross beta & 8 & $9310(\mathrm{SW}-846)$ \\
\hline Tritium & 500 & ASTM D2476-81 \\
\hline
\end{tabular}

Table B-8. Indicator Parameters.

\begin{tabular}{|c|c|c|}
\hline Constituent & CRQL (ppb) & Method \\
\hline Conductivity & N/A & ASTM D1125-A \\
\hline pH & $\pm 0.05^{\mathrm{b}}$ & ASTM D1293 \\
\hline Total organic carbon & 1000 & $9060(\mathrm{SW}-846)^{\mathrm{c}}$ \\
\hline Total organic halides & 10 & $9020(\mathrm{SW}-846)^{\mathrm{c}}$ \\
\hline
\end{tabular}

ASTM (1988)

BpH units

EEPA (1986).

\section{B.1.4 QUALITY ASSURANCE/QUALITY CONTROL}

\section{B.1.4.1 Quality Assurance}

Quality assurance (QA) will be conducted in accordance with the RCRA Groundwater Monitoring Project Quality Assurance Project Plan (PNL 1989b). A QA Plan describing the manner in which specific QA requirements are to be met has been prepared in accordance with that manual.

\section{B.1.4.2 Quality Control}

The purpose of quality control $(Q C)$ is to determine and document the quality of the analytical results being produced by the laboratory and to bring potential problems with analyses to the attention of the contract laboratory for corrective actions, if needed. The QC effort has two main 
components: (1) routine internal checks performed by the contract laboratory and (2) external checks conducted by PNL to independently evaluate contract laboratory performance. The scope of these efforts is described in the following sections.

\section{B.1.4.3 Contract Laboratory(s), Internal Quality Control}

Internal QC at contract laboratory(s) will include general practices applicable to a wide range of analyses, as well as specific procedures stipulated for particular analyses and will be carried out in conformance to SW-846 (EPA 1986). The QC and QA programs at contract laboratory(s) w111 be documented in $Q C$ and a $Q A$ manual. The contract laboratory(s) wil1 produce a quarterly QC report to PNL, which includes blank, matrix, spike, and surrogate data.

\section{B.1.4.4 Contract Laboratory(s), External quality Control}

PNL w111 use interlaboratory comparisons, replicate, blank, and blind samples to evaluate the accuracy of results from contract laboratory $(s)$. The purpose and scope of each of these follow and are summarized in Table B-9.

Interlaboratory comparisons using field samples are conducted to determine if the results obtained by the primary contract laboratory are comparable to those obtained from other laboratories. Currently, comparisons are being conducted for antons, selected volatile organic constituents, metals, cyanide, gross alpha, gross beta, and tritium. Each month repilicate samples from selected wells are delivered to four different PNL laboratories. The results from these PNL laboratorles are then compared with the results from the contract laboratory. Samples sent to PNL laboratories are from the same sampling set as those to be analyzed in duplicate by the contract laboratory (s).

Replicate analyses of field samples are conducted to establish how much varlability might be expected in the laboratory measurements performed on nearly identical samples and as a check on gross errors. Bianks for a wide range of analyses are submitted to the contract laboratory monthly to check for container, field, or laboratory contamination.

Trip (transport) and transfer blanks are submitted to the contract laboratory (s) to determine whether environmental conditions encountered during collection and transportation of samples have affected the results obtained by analysis. One set of trip and transfer blanks are submitted each sample period per sample area at the rate of at least one for 1 to 20 wells. These blanks are analyzed for volatile organic constituents.

Blind samples are submitted to the contract laboratory(s) to estimate the bias of analytical laboratory procedures and to determine when this bias exceeds control limits. Blind standard samples prepared by PNL containing metals, anions, herbicides, pesticides, and volatile organic compounds have been submitted quarterly since January 1986. Most blind samples are now prepared with materials supplied by the U.S. Environmental Protection Agency, including the previous list of analytes plus ammonium ion, cyanide, semivolatile compounds, polychlorinated biphenyls, and an expanded number of 
Table B-9. Summary of Quality Control Samples Required for the SALDS Groundwater Monitoring Program.

\begin{tabular}{|l|l|}
\hline Type of quality control sample & \multicolumn{1}{|c|}{ Frequency for SALDS program } \\
\hline \multicolumn{1}{|c|}{ Contract laboratory external quallty control samples } \\
\hline Field duplicate & $\begin{array}{l}\text { At least one per } 20 \text { samples or 5\% of the } \\
\text { total number of samples, or one per } \\
\text { sampling event, whichever is greater }\end{array}$ \\
\hline Split sample & $\begin{array}{l}\text { At the discretion of Geosclences group } \\
\text { manager }\end{array}$ \\
\hline Blind sample & $\begin{array}{l}\text { At the discretion of Geosclences group } \\
\text { manager }\end{array}$ \\
\hline Field transfer blank & Same frequency as field duplicates \\
\hline Equipment blank & Same frequency as field duplicates \\
\hline Trip blank & At least one per day of sampling \\
\hline Full trip blank & $\begin{array}{l}\text { At least one per } 20 \text { samples or one per } \\
\text { sampling batch }\end{array}$ \\
\hline \multicolumn{1}{|c|}{ Contract laboratory internal quality control samples } \\
\hline $\begin{array}{l}\text { Matrix and matrix spike } \\
\text { duplicates }\end{array}$ & $\begin{array}{l}\text { At least one per analytical batch or one } \\
\text { per } 20 \text { samples analyzed }\end{array}$ \\
\hline Quality control reference samples & $\begin{array}{l}\text { At least one per analytical batch or one } \\
\text { per } 20 \text { samples analyzed }\end{array}$ \\
\hline
\end{tabular}

SALDS - state-approved land disposal structure.

pesticides and volatile organic compounds. Samples containing constituents not available in U.S. Environmental Protection Agency performance samples are prepared from high-quality chemicals. These include constituents from the enhanced thiourea and phosphorous pesticides, group analyses, plus ethylene glycol, sulfide, perchlorate, and hydrazine dioxin.

\section{B.1.5 REFERENCES}

APHA, 1985, Standard Methods for the Examination of Water and Wastewater, 16 th ed., published jointly by the American Public Health Assoclation, American Water Works Association, and Water Pollution Control Federation.

ASTM, 1987, "Standard Test Methods for Plutonfum in Water," Annual Book of ASTM Standards, ASTM D3865-82, American Society of Testing and Materials, Philadelphia, Pennsylvania.

ASTM, 1988, "Standard Test Method for the Radionuclides of Radium in Water," Annual Book of ASTM Standards, ASTM D2460, American Soclety of Testing and Materials, Philadelphia, Pennsylvania. 
EPA, 1984, Test Method for Determination of Inorganic Anions in Water by Ion Chromatography, EPA-600/4-84-017, Environmental Monitoring and Support Laboratory, U.S. Environmental Protection Agency, Cincinnat1, Ohio.

EPA, 1986, Test Methods for Evaluating Solid Waste Physical/Chenical Methods, 3rd ed., EPA SW-846, U.S. Environmental Protection Agency, Washington, D.C.

Krieger, H. L., and E. L. Whittaker, eds., 1980, Prescribed Procedures for Measurement of Radioactivity in Drinking Water, EPA-600/4-80-032, Environmental Monitoring and Support Laboratory, U.S. Environmental Protection Agency, Cincinnati, Ohio.

PNL, 1989a, Procedures for Groundwater Investigations, PNL-6894, Pacific Northwest Laboratory, Richland, Washington.

PNL, 1989b, RCRA Groundwater Monitoring Project Quality Assurance Project Plan, PNL-7225, Rev. 0, Pacific Northwest Laboratory. Richi and, Washington. 

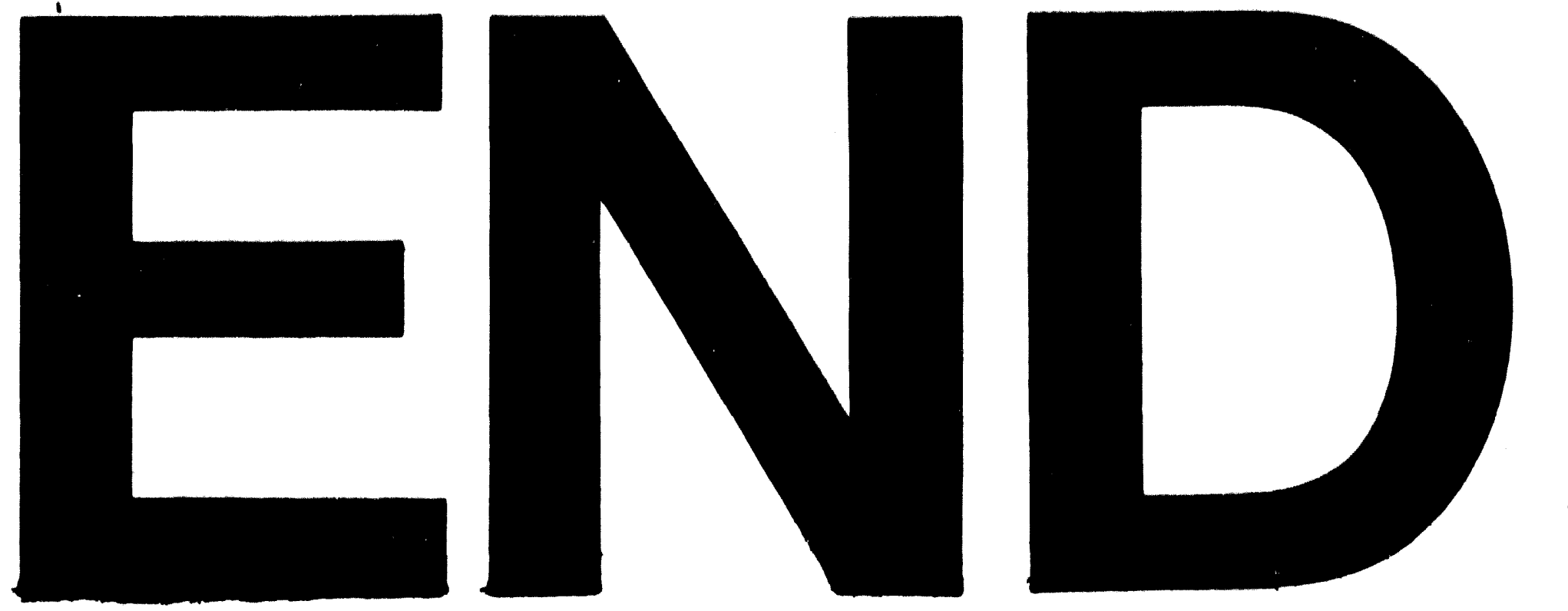

1
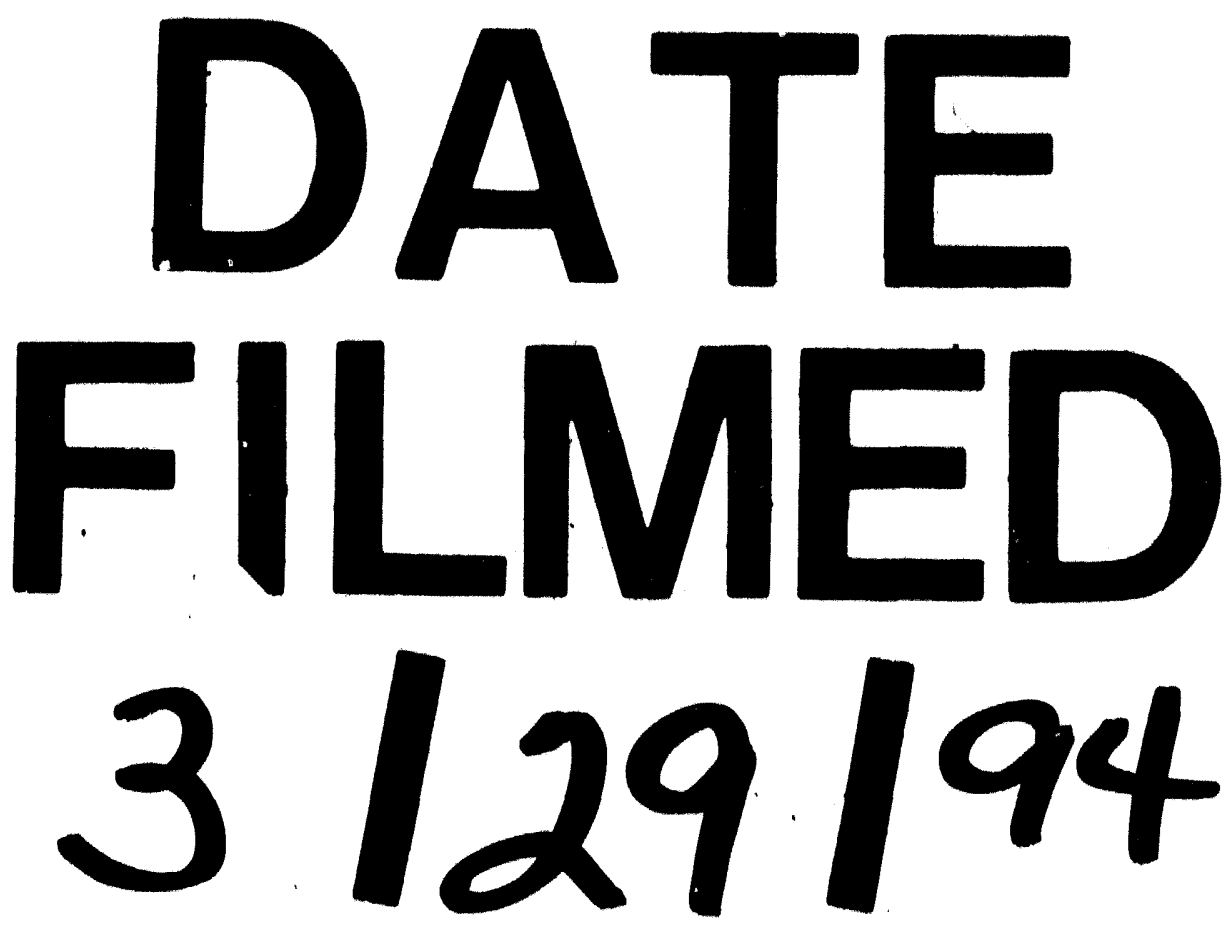

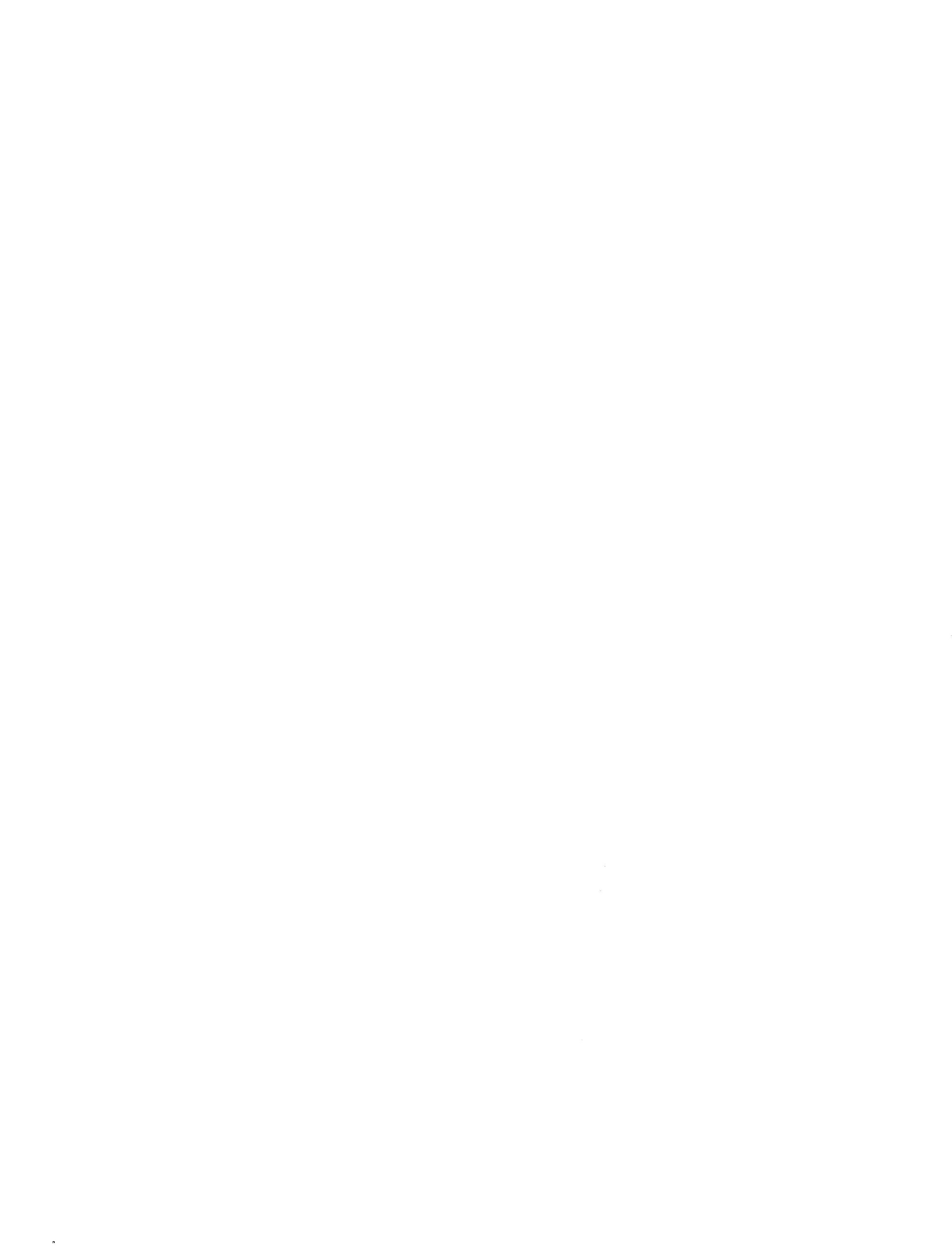